\title{
A STUDY OF IN VITRO OVULATION IN THE SPADEFOOT TOAD,
} Scaphiopus bolbrooki

By

KEITH L. HANSEN

\begin{abstract}
A DISSERTATION PRESENTED TO THE GRADUATE COUNCIL, OF THE UNIVERSITY OF FLORIDA IN PARTIAL FULFILMENT OF THE REQUIREMENTS FOR THE DEGRE OF DOCTOR OF PHILOSOPHY
\end{abstract}

UNIVERSITY OF FLORIDA

August, 1955 


\section{ACXNOMTHDGMEMTS}

Mang Individuals have offered helpful suggestions and erit1clams, and sor these I udh particularly to thank Drs. J. V. Slater, J. H. Oregg, A. Y. Cerr, I. I. Plerce, and I. S. Tord. Speclal

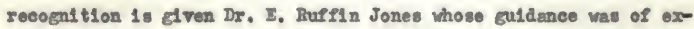
treme benef1t in the preperation of this menuacript during the 111ness of my chnirmen. I gxatefully acknowledge the sasistance of $\mathrm{W}$. Prophet and 3. Dav1s in preparing the photographs. Appreclation 1: expressed to the College of Arts and Solences for the craduate Pellowshlp cranted from September, 1954, to Arguet, 1955. Two persons deserve apeolal acknowledgment. My chatraan, Dr. Coleman J. Goln, has strpervised my aendente progran, has gulded my research, and has glven ae continued stinulation and Inspiration. My wfe, Nita 9. Hansen, has helped physically in the study, has carefully edited and fiven suggestlons in the miting of this report, and has provided, nost ably. Ilnancial and morel support. 
L1 st of Tables Page

Ilet of Illustrations ................. vil

LIst of Plates ................... v111

Introduction ...................... 1

Materials and Methods ............... 5

Procedures and Restalts .............. 9

Factors Affecting In Vitre Ovuletion......... 9

Comparative potency of nele end fenele pitultary . . 9

Individual variation in ovalation in vitre ...... 13

Relationahips of toad ize to in vitro ovilation... 15 Effect: of pltultary dilutions upon In yitro

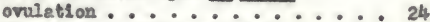

Relatlonship of time to in vitre ovulation......27

iffect of light upon in vitro ovalation....... 32

iffect of temperature upon in vitre ovilstion.... 33

Effect of pH on In fitre ovilation........ 35

sffects of heteroplastic pitultary materials

upon in vitre ovilation...... 42

Phylological and Icologleal Relations to the Breeding St1malus....... 50

Breeding season ............... 51

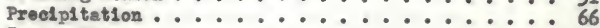

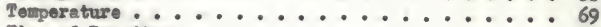

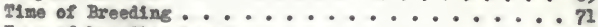

Type of breeding ponds ............. . . . . . .

Multiple breedings in a aingle year........ 73

Ixtended perlods of t1me w thout breeding ..... 75

Ixperimental Procedures and Results Having

Icologleal Implleatlons..... 76

Iffects of $11 \mathrm{ght}$ and derkness on fenale toads . . . 79

Iffect of abrupt changes of temperature on

female toads.......... 82

Ixponure of fenale toad to lovered atmospherle

pressure .......... 85 


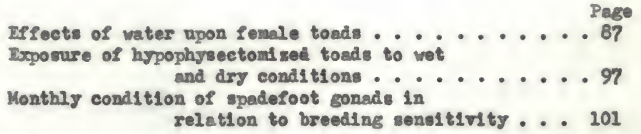

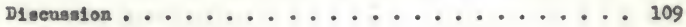

sumnary ................... 126

Il terature Cited .................. 130

Blographical sketch ................ 143 


\section{LIST OF TABLES}

Table

1 Comparat1ve Poteney of Male and Ienale P1tultery . . 11

2 Individual Variation of In V1tro Ovulation...... 14

3 nTw Tests for Statist1cally Slenl2leant Differences

between Mean Ovvlat1on Percentages ...... 16

4 Relationship of P1tuitary Donor $\$ 1$ ze to In Vitro

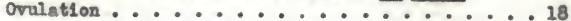

5 Relat1onghip of Mele P1tuttary Donor 51 ze to

In vitro orvalation ............. 19

6 Values (t.) Irom rests for stetist1 callg $\$ 1$ gnifieant

Differences between Ovulat1 on Percentages Induced

by P1tultarles fros Differsnt \$1 ged Donors ... . 21

7 Coefflelent of Correlat1on Values between Donor

Toads and Percent Ovulation .......... 22

8 Relationships of Ovary Donor s1ze to In Vitro

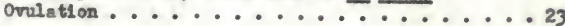

9 Bffects of P1tuitary D11utions upon In Vitro

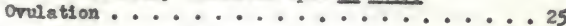

10 Iffect of Light on In Iitre Ovalat1on ....... 34

11 Iffect of Teipernture on In Iltre ovulat1on..... 36

12 Rrfect of $\mathrm{pH}$ on In Fitre 0vulation .........40

13 Mrfects of Heteroplast1c Pltultary Materials upon

In V1tro Ovulation .............44

14 Spederoot Toad Breeding Records .......... 52

15 In Iitre Ovolation Results Obtained fron Fenales

Ixposed to Lleht and Darkness . . . ...... 81

16 In Vitre Ovulation Percentages Obta1ned from Temale

Toads Ixposed to Abrupt Chenges of Tenperature...84 


\section{IIST OF TABITS - Cont1nued}

Table

Page

17 In V1tre Ovilation Results fron Foads Ixposed

to Iovered Atrospher1c Pressure . . . . . . . 88

18 In Fitre Ovulation Percentages Obtained Using Ovarles Taken Iron Females Subjected to Wet and Dry Conditions for 48 hours .......... 91

19 Tests for Statistleally S1gnilicant Differences between Percent Ovulation and Molsture

Relationahlos................ 93

20 In Vitro Ovalet1on Results rollowng Exposure of Fenele Toads to Different Funddit1es ....... 96

21 In V1tre Ovalation Results Obtalned from Hypophysectoinsed and Dormal Toed after Subjection to Vet and Dry Conditions............ 100

22 Couparative Monthly Rat1o of Ovary We1 ght to

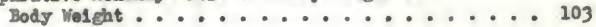

23 Monthly Sensitivity of Tomale Toads to In Vitro

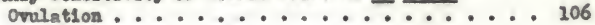


IIST of ILLUSTRATIONS

P1 gure

1 A Comperison of the Potency of Male and Fenale Pltud tary Glands ............... 22

2 In Vitre Ovulation Reeul ts Obtained fros Various Concentrat1ons of P1tuttary Sugpenslons . . . . 26

3 Progress of In V1tro Ovulation Irom Your Different

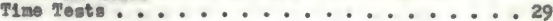

4 Percentege of In Vitre Ovalation Recorded Fourly . . . 30

5 Iffects of Pltustary Dilutions upon the TI ne Reguired to Inttiate In Vitro Ovriation ..... 31

6 In Vitro Ovulat1on after Exposture of Ovarien Fragments to a Range of Tenperatures ...... 37

7 Iffect of Hyirogen Ion Concentret1ons upon In Vitre ovriation ................. 42

8 Diegramatic Phylogenet1e Tree Shoulng the Ceneral Iffect of Varlous Pltultary Materials upon In V1tre ovilat1on ............ 49

9 Monthly Breeding Records of Spadefoot Toads fron the Horthern, Centrel and Southern Portlons of the ange .............. 65

10 Correlation of Fainfall with Spadefoot Breeding in the state of Ylorida ........... 67

11 In V1tre Ovulation Reavits Obtained fron Fenale Toads Erposed to Viet and Dry Conditions ........ 92 


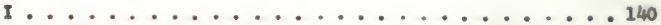

19. 1. Single exci sed spedafoot overy containing nine egs-f11led lobes.

71G. 2. Vial-rack holding vials whtch contaln ovarian Iragments surpended on cotton thread in pltuitary extract.

F1g. 3. Control vial contalning only Holtireter's solution and experinental vial contalning HoltIreter'g solution and pitud tary homogenate.

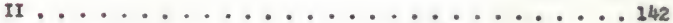

Mig. 1. Ventral view of exclsed spedefoot crantun severed through the cervical region and angle of the Jav.

I16. 2. Cranlum shoulng exposed parasphenold bone after the renoval of the oral mucosa fron the roof of the moth.

F1e. 3. Crantun wh brain case opened ventrally, woulng the exposed pltustary just posterior to the opt1c chisame. 


\section{IMMrodocruos}

The Irat experimants concerned with the Induction of orviation by the implantation of pituitary flands vere performed on mannals (Asche1m, 1926; 8mith, 1926; 2ondsk, 1926). S1nce then meny workers have demonstrated that pituitary materials vill induce ovilation in representatives from most of the vertebrate clanges (Ostelchthreg: Houssay, 1931; Ioble, 1936: Amphibla: Wolf, 1929: Rugh, 193h; Rostand, 1934; Shap1ro, 1936; Rent1118: Houseay, 1930; Cunninghen and Smart.

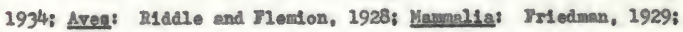
H1 say et el.. 1935, and many others).

Because of the simplicity of 1 te ovarian structure and general

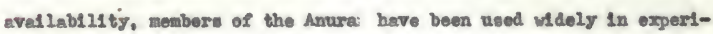
mental studies of goned-endocrine relationshlps. Structurally, the anuran ovary is essentielly a hollow sac vhose walls conalst of a double vembrene containing scattered snooth muecle cells and ogs foll1clew. As the roll1cles nature, they stretch the Inner cell lager and gradually projeet into the cavity w thin the ovary. In ovvlation, the ovas pesses through the thin outer nembrane into the coelonle cavitg. The process of ovulation and the anatorg of the ovary heve been thoroughls deser1bed by Ruph (1935).

The early in fivo expeximents involving pituitary injection and hypophysectomy revealed considerable information concerning 
species speciflelty and seasonal periodiclty in Amphibla (Houssay and 01ust1, 1929; Adams, 1930; Adams and Cranger, 1936; Creaser and Gorbman, 1939). Iugh (1937) presented quant1tative data on differonces in hormone potency in male and fenele gonadotropic factors, seasonal variation in the concentration of pltultary hornones, and varlations in response by reciplent femeles of different ise and maturlty.

In 1935 Augh thowed that excised orartes srom Rena diflens would orulate normally in Ringer's solution when their donors were injected Wh th pltultery meterlal s some hours before the removal of the ovary. In the p1rat experinents exclusively employing the in vitise orulation technique (He1lbrunn, Daugherty, and M1bux, 1939), whol untreated ovarles were surpended In RInger's solution contalning maerated p1 tul tary glands. Ovulation occurred in twelve to twenty hours, and all eggs so ovulated showed first polar body formation at do egg ovilatling naturaliy.

Iyan and Grant (1940) developed a silght modirication of this techntque by plecing amall pleces of ovary Irom Rana plofens in Ringer's solution to mich mecereted p1tud targ concentratlon: had been added. These workers helped to establish the norneley of in Fltre ovulation by artifiolally fert111zing oges whlch had bsen placed in the coelom of an ovarlectomized female and alloved to pasa through the ovlducts to recelve a jelly coat. Such egs cleaved normelly and ang batehed 1nto swanding larvee. 
In 1945. Wright deser1bed some of the quant1tat1ve and b10chealeal appects of In Itre ovilation In Rens piplens. He wowed that the ovilation remponse in vitre varied seasonellg es Rugh (1937) had demonstrated in yive. He also considered the effects of pitultery dosage, temperature, and the relationship of tias to in Itre ovalat1on. Wright and Fisaw (1946) demonstrated that mamalien pltultary extracts (ISH and LiH) ellcit ovulation both In viro and in vitre. $A$ combination of FSF and Li produced ovulation in normal and hypophysectomized frogs as well as in ovarian fragments in Vitre. Wright (1946) reported that hypophysectory brought about an increased remponsiveness of the ovary to pituitery substances in ittre. This temporary sensitization of the ovary was thought to be cauned by the release of gonadotropins from the anterior lobe during the course of the operation. This hypotheals was strengthened by the increase of ovulation in vitre found following the Imereion of ovarlan pleces in sertun taken fros hypophysectond zed frogs (Wright and Macintyre, 1950).

No In vitre ovulation studies have been done on the eastern spadefoot toad (Scaphlowas holbroold). In fact, relativaly 11ttle is know about this toad' reproductive phyalology or breeding eycle. Fleld data Indicate that this species is quite romariable in 1 ts ablilty to breed over a vide number of months (January to Oetober). It appears that the spadefoot doe not follow s seasonel pattern of breeding 11ke that of most Amphibia, but breeds at any tise of the 
year when enviromental conditlons axe sultable. It has long been recogen sed by herpetologlsts and naturullsts that this species $1 \mathrm{~s}$ stinalated to breed by heavy ralnfall durlng the warner months. The exect wechant am by which this environsental gtimulus affeots the toad 18 nnicnom.

Using the technique of in ditre ovilation, it was hoped that this study ulght contribute toward a better lmowledge of the physlologIcal processes Involved in ovulation as well as the netural-hormonal process Involved in the breeding response of the epedefoot. The purpose of the present Investigation was therefore twolold: I1rst, to study a muber of fectors affecting ovilation in vitre, and second. to attempt to discover some of the physiological and ecologleal factors Involved in the breeding of the spaderoot toad. 


\section{MATRRIAIS AND METHODS}

Approxdmetely 1007 spedefoot toeds were used in the study. All vere collected from a spacious dalry pasture located about six miles southwest of Gafnesville, Mlorida. Collectlons were made at night, ith the ald of a head 11 ght powered by a six-volt battery. Toads were easly located by the reflection of the l1ght from their e ges.

Following collection, the sexes were separated in the laboratory. Spadefoot: were pleced in square-shaped gallon Jars, each containing ten to twelve toads. A thin 11 in of weter in the botton protected the antinals fron desiccation. The water wa changed. periodically. The jar lids were set on loosely to allow sufficient fresh elr. The spadefoots were stored in a refrigerator set at $12^{\circ} \mathrm{C}$. where they could be kept in a state of dormancy for several months whout leeding. Most toads, howevor, ware used during the same month in which they vere collocted.

In general, the laboratory procedures were similar to those degeribed by Wright (1945). The ovarian donors were moderate to large fenales welghing from 10 to 22 grams and having head vidthe varying from 18 to $23 \mathrm{mas}$. It was found that no relationahip exlsted between the $1 \mathrm{ze}$ of the femele and the size or maturity of the eggs. Thus a wde range of sl zes could be ut1lized. By pressing upon the abdominal vall and pushing one ovary to the trangparent groln axea, 
each femele was examined for a full complement of nature eges. In this ver, immature or berren femeles vere culled rather than needlessly sacriflced.

The ovarles (Pl. I, 11g. 1), which are af milar to those of other enurans in structure, were removed from freshly bdlled fenales and placed in a Petri dish contalning $30 \mathrm{ml}$. of Foltfreter's solution (normal solution), which is approximately 1sotonic with amphibian embryonic t1smes (Holtfreter, 1945). The ovarles were later removed from the solut1on, welghed, and then cut 1 nto small pleces containIng twenty to thirtj-LIve eggs each. These fragments were suspended. by cotton threads in stoppered vials containing 10 ml. of Holtrreter's solution (P1. I, f1gs, 2 and 3). P1 tuitary homogenate, usually prepared from the anterior lobes (pars d1stal1s) of adult male toads, was added to this fluld to induce ovulation.

The extirpation of the pituitary gland was relatively simple. By means of a quick out with sclasors through the angle of the mouth and across the cervical region, the entire crantum was removed from the body and lower Jav. A second transverse cut removed the remainIng cervical vertebrae and exposed the foramen magnum (P1. II, Pig. 1). The sidn covering the roof of the mouth wes pulled off anterlor1y w th a pair of heavy forceps (PI II, I1g. 2). Fech lateral profection of the exposed T-shaped parasphenold bone was eut wh a pair 
of fine-pointed selssors. Then one blede of the scissors ves inserted Into the foramen megmum, laterel to the modulla, and, wh th the other blade resting upon the lateral process of the perasphenold bone, s single cut was made along elther side of the ventral surface of the brain case. The bony flap thas formed was folded anteriorly. exposing the ventral surface of the brain with the pitultary gland attached to the infundibulo-tuberal region of the hypothalemus, fust posterior to the optic chlasma (PI. II, f1g. 3). The pars distelis 1s a round glandular portion of the hypophysi s and is eagily removed from the pars nervosa (posterior 1000) and pars intermedis (Intermedlate lobe) wth I1nomolnted surelcal forcegs.

Since a stendardized potency of pltuitary suspension was needed, fien mubers of male anterlor lobes were finely nacerated with the use of amall mortar and pestle. The nacerated homogenate was then resoved and dluted in an appropriate amount of Foltfreter's solution. The ratio of pitultery to normal fluid vas one anterior lobe to $10 \mathrm{ml}$. of Holtfreter's solution.

Blank controls of norneal fluid, without pltustary homogenate, were used in every experiment to check for possible spontaneous ovulation. All experiments vere allowed to stand for elghteen hours, and unless otherwlse Indicated, all tests vere conducted at a room temperature of $23.0 \pm 1.0^{\circ} \mathrm{C}$. 
Percentages of ovilation were deternined by dividing the number of eggs ovulated (1.e., falling to the botton of the v1al) by the total number of egga present in the ovarlan iragment, and multiplying by 100. All statistical conparisons were based upon the ovulation percentages. A complete sample of data may be seen in Table 10.

After data had been obtes ned on In vitro ovvlation, fomele toads vere subjected to certein stimull (e.g., lovered atmospherle pressure, presence of excess vater, etc.) before belng sacriflced for their ovaries in an atteapt to determine whether such st1 mall mi ght play a role in the breeding of the spadefoot tood in nature. Since the experimental procedures rarled, a detalled deseription of these is given along wh the results. 


\section{PROCEURIS AND RTSUITS}

\section{Ractore Afrecting In Vitro ovulation}

The folloving aspects of in vitro ovalation in the spadefoot toad vere consldered in this work: individual variation in ovalatIon; size relationshlps in pitultary and overian donors; comparative effects of male and female pltultary: innluence of varylng concentrations of pitultary suspensions; and, Infiuence of heteroplastie pitultary implents. The effects of certein physicel factors such $\mathrm{s} B$ 11ght, temperature, and $\mathrm{pH}$, and the relstionship of time to ovulation In vitro vere also etwdied.

\section{Comperative Poteney of Male and remale Pituitary}

Both Wright (1945) and gondell (1953), working on in v1tro ovulation in Rens pioieng, used pltuitery homogenates prepared from the anterior lobes of fenale froge only. Since all toads used in this study were collected by the writer, it seemed desirable to ut1lize the males (approximately fifty percent of the individuals taken) as a source of pituitary. Hovever, the question arose concerning the relative potency of the mele and female Gland since, In Rana plolens. Fuch (1937) found the pitultary of the male to be 16 percent heavier than but only 60 percent as potent as thet of the female. 
Two tests were designed to compere the relative potency of the male and female glands. In the firat test pituitaries vere removed fron $1 \mathrm{x}$ ales and $81 \mathrm{x}$ females of equal size. The gland vere placed on two tared cover-glipg and dried in an oven held at $60^{\circ}$ C. for twenty-four hours. Following the second welghing. appropriate dilutions were made to give a twelve-vial series for each sex. In each vial the equivalent of one-half of an anterior lobe was sugpended in $5.0 \mathrm{wl}$. of Holtfreter's solution. The effectiveness of these dilutions in inducing in pitre ovaletion was then teated with the reaults show in Table 1, and the nale pituitary was found to be 75.7 percent as potent as that of the female.

The second test ut1lized freshly triturated pituitary glands from five meles having a mean head wdth of 20.9 an. . and five females with a mean head with of $20.8 \mathrm{~mm}$. P1 tultary homogenates of the glands of each gex were prepared and distributed equally in ten Visls, each contalning $5.0 \mathrm{ml}$. of lluid. The ovilation results for the freahly macerated glands are recorded in Table 1. In the gecond experdment, the male pitultary proved to be 81,0 percent as potent as the female gland. If a mean percentage is taken for the two experiments, the mele glands are 78.2 percent as potent as the female glands. This is appreciably grester than the 60 percent reported for Rane plolens by Rugh (1937). A hlstogran presents the result for Seaphloous holbrooid in Figare 1. 


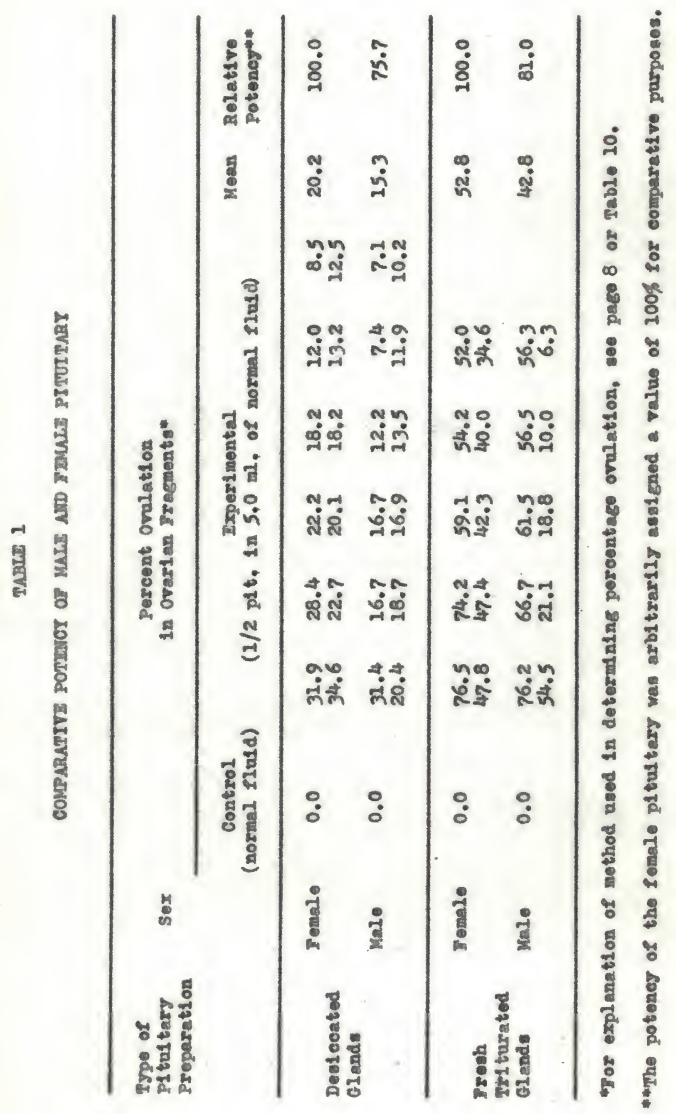




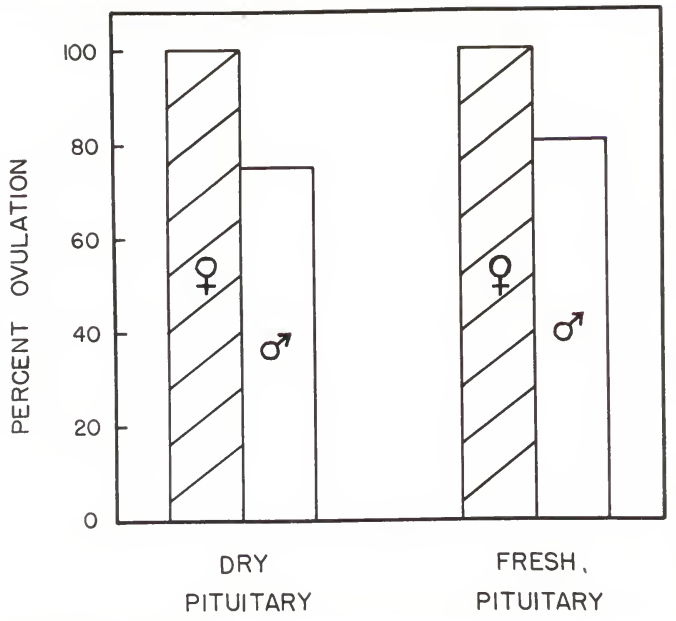

71g. 1. A conpurs son of the poteney of melo and femele pl tultary glands determinod by the in vitre ovilation technfque. For comparative purposen, an arbitrary value of $100 \%$ was ased mod to the potenoy of the fenele glands. 
Since weales vere reedily arallable from fleld collections, and sinee the potency of male anterlor pltultary lobes was sufflelent to produce a high percentage of ovulation, male pltultary was used almost exclusively throughout the present work.

\section{Individual Variation in Ovulation In Vitro}

Both wright (1945) and Fondell (1953), using Rana plpleng, Sound considerable variation in ovilation using the in vitro techntque. To give gtat1stlcelly satlsfactory recults, Rondell used a minimum of four pleces from random areas of the ovary of each of two frogs. In such an elght-vial serles recelving the same treatment, the variation in percentage of ovviation nover exceeded 15 percent.

To test the varietion in percentage of ovulation anong Individvals, in the present study. six femeles of appraximately the same size were used. Elght pleces of ovary were taken froveach toad and suspended in Fials contalning the equivalent of one-hals male pitutary in $10 \mathrm{ml}$. of solution. The Individual and mean percenteges of ovilation are recorded in Teble 2 along in th the standard deviation and etenderd error of the aeans. When Rondell's nethod of using four pleces of ovary from each of two frogs was applied, the greatest variation between extreme means proved to be 15.2 percent which Is almost Ident1eal to that found by Rondell. 


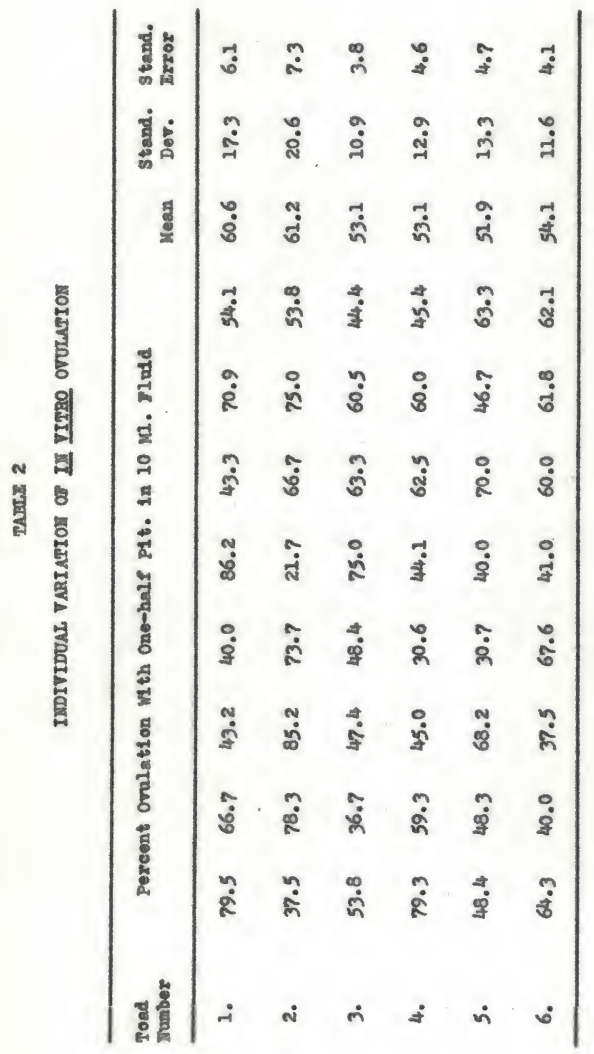


However, in order to have a st1ll further check on the vallaity of this technicav, the "t." test for statistically slgnificent differences was applled to the meens of the percentages of ovilation. The results shown in Teble 3 indicate that the differences between the neans lack stat1st1cal significance. It may be concluded, therefore, that individuel veriation in ovilation for toads subjected to the seme conditions, is not ereat enough to produce stat1et1cally slgnificant differences. Therefore, atatist1cel comperisons, shoulng sienticent differences for tosds exposed to varying conditions, way be relled upon as valld.

\section{Relationships of Toad S1ze to In Vitro 0vulation}

\section{Slze of Pltultary Donorg. It seemed logical to assune that} lerger animals possessed proportionately larger pl tultary glands and that these probably had a grester hornone t1ter. To test this assumption, lobes fron twenty-one male toeds rangling in head width from 17 to $23 \mathrm{~mm}$. wore selected. Their enterior lobes were renoved, mecerated Indiviônally, and sugpended in $10 \mathrm{ml}$. of Holtfreter's solution. Sach of these $10 \mathrm{mi}$. quantities was divided equally between two visls. In this menner, the potency of the pltultary of each tosd was checiced wth two pleces of ovary. The ovary, taken from a single female, was divided anong the forty-two vials of pitultery solut1on. The meen percentage of ovulation for each size 
TA3L 3

"Tุ" TESTS TOR STATISTICABLLY SIGNIZICAMTI

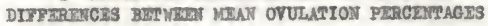

\begin{tabular}{ccccccc}
\hline Toads & 1. & 2. & 3. & 4. & 5. & 6. \\
\hline 1. & - & - & - & - & - & - \\
2. & 0.06 & - & - & - & - & - \\
3. & 0.90 & 0.92 & - & - & - & - \\
4. & 0.91 & 0.88 & 0.06 & - & - & - \\
5. & 1.05 & 1.00 & 0.15 & 0.18 & - & - \\
6. & 0.83 & 0.79 & 0.16 & 0.15 & 0.33 & - \\
\hline
\end{tabular}


clasa was as follovs: 23m.) - 35.7\%: 22 mo) - 37.2\%: $21 \mathrm{~mm}$ ) -

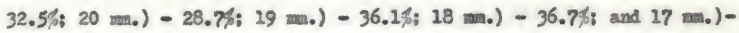
28.9\%. The individual orulation result are shown in Table 4.

The means of the various alze elasses showed only minor differences, and the coefficient of correlation $(x=+0.11)$ between the s1se of p1tuftery donore and percentege of ovulation was quite low: thls lacked statistical significance (Table 7) because of the amall numbers 1nvolved. Yrom this experiment, it appears that the size of pitultary donors (actually the alze of their pituitaries) has a negligtble effect upon in vitro ovulation.

SInce carefur body meagurements were taken of the male and fomale toeds used in all experiments, the relation of the pituitary si ae to ovulation could be studied further. It was possible to talco the ovalation date from all of the experiments (350 individual tests) in wich female toads vere not subjected to experimental condstions (Table 5). Again, a correlation value was sought. The coerflelent of correlation celeulated from these data gave a low negetive value, where $r=-0.16$. This test proved to be stat1at1celly signifleant with $t_{0}=3.06, P_{0}<0.05$ (Table 7).

The data given in Table 5 prement a rather complex pleture. The meen of the percentages of ovilation for each size class, at the different pituitary allutions, were compered statisticelly. 
TABLE 4

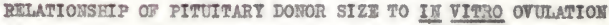

\section{Foed.}

Number

\section{Percentages of ovvilation for $\$ 1 z e$}

Classes of Male pltuitary Donore

\begin{tabular}{llllllll}
\hline 23 & 22 & $\begin{array}{l}\text { Head with in mili meters } \\
21\end{array}$ & 20 & 19 & 18 & 17 \\
\hline 33.9 & 51.2 & 39.2 & 27.3 & 31.8 & 55.8 & 31.9 \\
38.0 & 16.9 & 32.1 & 23.1 & 39.3 & 17.6 & 26.5 \\
35.1 & 43.6 & 25.8 & 35.6 & 37.2 & 36.6 & 28.4 \\
\hline
\end{tabular}

$\begin{array}{llllllll}\text { Mean } & 35.7 & 37.2 & 32.5 & 28.7 & 36.1 & 36.7 & 28.9\end{array}$ 


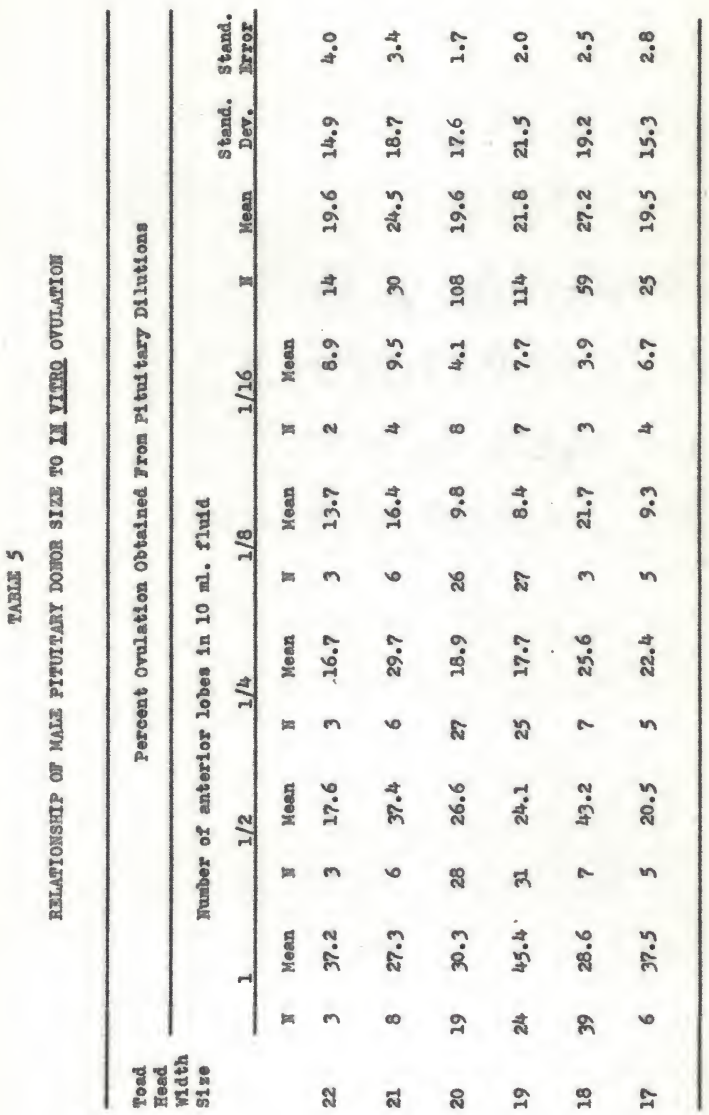


Table 6 shows the various comperisons, visins the "t." test. between the slze group neans. Only that betwenn the 18 and $20 \mathrm{man}$. Eroups ghows gtat1stically significant differences. It would appear, therefore, that the size of the pituitary donor is not correlated with the percentace of oviretion induced.

S1ze of Overy Donore. In the preliminary stages of the work. It was learned thet small, golk-deficlent eggs seldom ovulated normally, therefore, Immature eggs were avolded. It seemed desirable, however, to deterud ne whether there was any correlation between the size of toads and the maturity of their eggs.

Femeles verying in head wdth from 17 to 23 mas. were divlded Into seven size classes. Two females were selected for esch size class, and two pleces of ovary were ued for each of these. Iach else class was therefore represented by a four-vial series in which each viel contalned the equivalent of one-half pitultary in 5 ril. of fluld. The Individuel and mean values for percentage of ovulation In the varlous classes are shown in Table 8 . The correlation between size of female and percentege of ovalation appeers to be practically atl, and this 1 s supported by a statistical anslysis. The coefficient of correlation proved to be very low $(x=+0.06)$ al though not significent statistically (Table 7) because of the smell mumbers 1nvolved. 


\section{TABT: 6}

VATUES (t.) FROM TESTS FOR STATI STICAILY

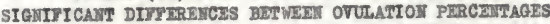
INDUCED BY PITUTTARIIS PRON DIYPTRENT SIZED DONORS

\begin{tabular}{ccccccc}
$\begin{array}{c}\text { Male Toad } \\
\text { Head Mith } \\
\text { S1 se }\end{array}$ & 17 & 18 & 19 & 20 & 21 & 22 \\
\hline 17 & - & - & - & - & - & - \\
18 & 1.98 & - & - & - & - & - \\
19 & 0.68 & 1.65 & - & - & - & - \\
20 & 0.05 & 2.48 & 0.42 & - & - & - \\
21 & 1.23 & 0.62 & 0.67 & 1.26 & - & - \\
22 & 0.04 & 1.55 & 0.47 & 0.005 & 0.90 & - \\
\hline
\end{tabular}




\section{TABLE ?}

COETICIENT OF CORRELATIOI VAJUES BETVMAY

DOMOR TOADS AID PERCDNT OVULARIOI

\begin{tabular}{|c|c|c|c|c|}
\hline Tests & 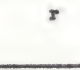 & $\begin{array}{l}\text { Stendard } \\
\text { Devistion }\end{array}$ & $t$ & $p$ \\
\hline $\begin{array}{l}\text { Test between size of } \\
\text { pituitary donors ( } 20 \\
\text { meles) and ovulation } \\
\text { induced. }\end{array}$ & +0.11 & 0.22 & 0.48 & No't $81 \mathrm{gn}$. \\
\hline $\begin{array}{l}\text { Test between size of } \\
\text { pitultary donors ( } 350 \\
\text { males) and ovnlation }\end{array}$ & -0.16 & 0.05 & 3.06 & P.<0.05 \\
\hline $\begin{array}{l}\text { Test between size of } \\
\text { ovary donors and } \\
\text { percent ovulation }\end{array}$ & +0.06 & 0.19 & 0.32 & Tot sign. \\
\hline
\end{tabular}




\section{TABLE 8}

RELATIOISHIP OF OVARY DOHOR SIZE TO II VITRO OVULATIOI

\section{road}

Number

\begin{tabular}{|c|c|c|c|c|c|c|c|}
\hline \multirow{3}{*}{1.} & \multirow[b]{2}{*}{23} & \multirow{2}{*}{\multicolumn{2}{|c|}{ Head }} & \multicolumn{2}{|c|}{ In millimeters } & \multirow[b]{2}{*}{18} & \multirow[b]{2}{*}{17} \\
\hline & & & & 20 & 19 & & \\
\hline & $\begin{array}{l}86.4 \\
75.2\end{array}$ & $\begin{array}{l}70.6 \\
65.0\end{array}$ & $\begin{array}{l}74.7 \\
65.1\end{array}$ & $\begin{array}{l}59.2 \\
67.4\end{array}$ & $\begin{array}{l}71.2 \\
48.4\end{array}$ & $\begin{array}{l}80.4 \\
73.0\end{array}$ & $\begin{array}{l}57.2 \\
52.0\end{array}$ \\
\hline 2. & $\begin{array}{l}61.1 \\
32.3\end{array}$ & $\begin{array}{l}33.0 \\
27.2\end{array}$ & $\begin{array}{l}57.9 \\
67.2\end{array}$ & $\begin{array}{l}38.1 \\
41.9\end{array}$ & $\begin{array}{l}22.1 \\
24.8\end{array}$ & $\begin{array}{l}60.1 \\
42.1\end{array}$ & $\begin{array}{l}62.0 \\
43.2\end{array}$ \\
\hline Mean & 63.5 & 46.5 & 59.9 & 51.7 & 41.6 & 63.9 & 53.6 \\
\hline
\end{tabular}


Iffects of P1 tuitary Dilutions Upon In V1tro ovvlation

Wright (1945) found that one-ighth of an anterior lobe suspended in $10 \mathrm{ml}$. of Holtfreter's solution produced maximam in Vtro ovilation in Rana plofens, but it was necessary to establish the optimal amount of pitustary necessary to produce approximately maximal ovilation in the spadefoot. Tor this purpose, forty-nine mele pituftary donors and three femele overy donors were gelected. To avoid Individual variation in potency, a standerdized stock solution of pitultary was prepared. The desired concentrations (from six glands to one sixty-fourth of a gland per $20 \mathrm{ml}$. of Eoltfreter's solution) were obtained by ufding together appropriate amounts of this stock aolution and of Holtfreter's solution. The records of ovulation and the mean vilues for each pituttery dilution are found in Table 9. The curve in Ilgure 2 show these data In exaphic forn. The ovulation percentages for the various pituitary dilutions are as follows: six pltuitaries in $10 \mathrm{ml}$. of fluid -7.5 percent; f1ve - 28.5 percent: four -44.4 percent: three -59.5 percent; two - 61.8 percent; one - 64.5 percent; one-hale - 42.1 percent; one-fourth - 22.5 percent; one-elghth - 11.1 percent: one-s1xteenth - 4.3 percent; one thirty-8econd - 1.4 percent; one sixty-fourth -0.0 percent. 


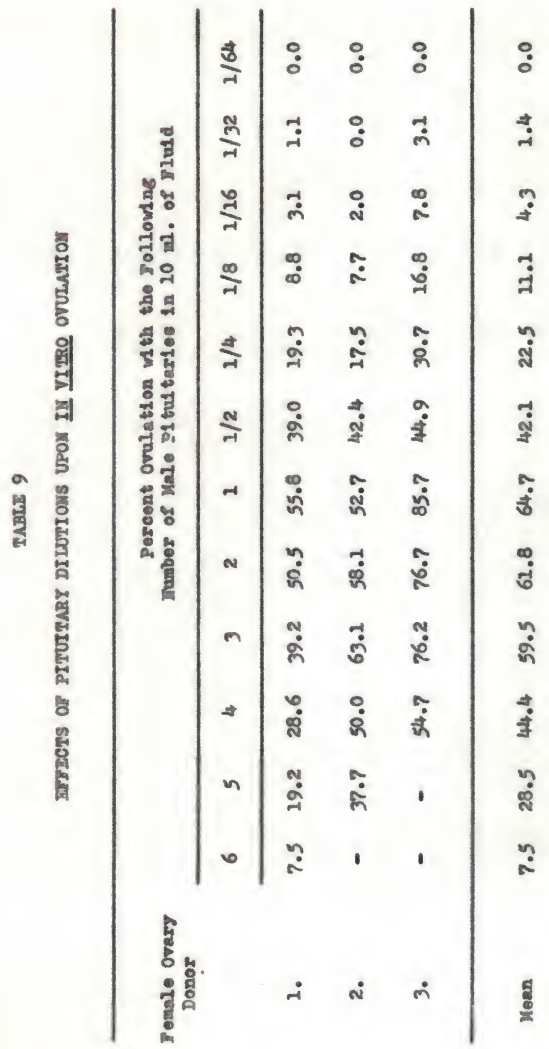




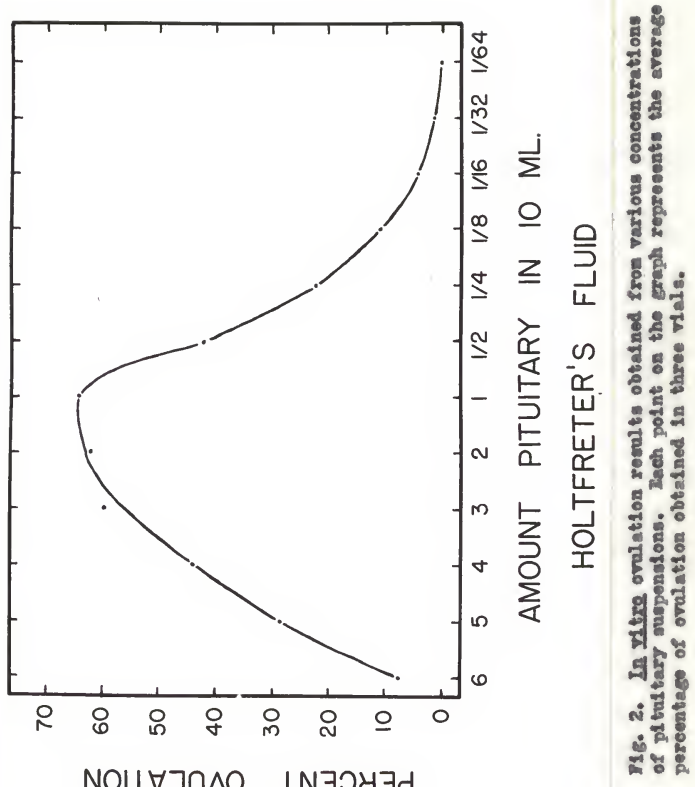


Yrom this experiment it was foind that one pituttary in 10 mil. of flutd produces eseentialiy maxdmal ovulation. It is also ovident from these reauls that ovilation ia inhibited at higher p1tultary dilutions, which is in accordence wh thet (1945) who found inhibition of ovalation in Rana piofeng when using greeter concentrations of pituitary. The results of the present study are anflar to those of Foster, Foster, and H1sav (1937) who found that ovilation in mammals may not follow the adulistration of larger doses of an wiractionated pituitary preparation.

\section{Relationship of Tine to In V1tro Ovulation}

In order to ensure the sccuracy of the results. It was necessary to determine the time reguired for the ovulation process to reach a atage where eggs vere no longer ovvisted. Wright (1945), using Rana pipiens, performed a time experiment at roon temperature $\left(22^{\circ}\right.$ c.) with dilutions of one-elghth of a pitultary in $10 \mathrm{ml}$. of Boltsreter's solution. Fe found that ovalation ald not gtart unt1l about the tenth hour, and that when dilute pituitary dilutions vere uged (1.0.. one sixty-fourth or one, one hundred twenty-elghth pitul tary in $10 \mathrm{ml}$. of fluid), orvilation did not begin for alxteen to elghteen hours.

Four different-tests were conducted in the current work. Fach employed a four-vial series. Each vial contained a pitultary 
homogenate equivalent to one pltultery in $10 \mathrm{ml}$. of solution. The hourly progress of ovulation 1s shom in Migure 3. From these four curves 1t may be seen that in vitro ovilation began about three and one-half hours after the ovarlen fragnents were placed in the solntion. Once the process vas inftiated, ovilation was nost rapid in the folloving three hours when approdimately seventy-live percent of the egga ovulated. ovriation was completed in all experiments efter eight and one-half to eleven and one-half hours.

This series of experiments also showed thet maximal ovulation occurred during the sixth hour. A curve, the polnts of which represent the ovulation percenteges for each hour, presents these data in 11gure 4. Might (1945) found, however, that this took place between the thirteenth and seventeenth hours in Rens plpiens using a one-eighth pitultary dilution.

Wrieht's study further indicated that lower dilutions of pitultary took longer to initiate orulation. In order to teat this for Scaphlooug holbroold, a serles of Ilve pltultary allutions vere prepared, ualng from one to five glands in $10 \mathrm{ml}$. of Rluid. For each concentration, $5 \mathrm{ml}$. of solution were placed in each of two vials so that a double test might be used. The results are presented graphicaly in the form of five curves representing the different pituitary concentretions (F1g. 5). The four-pituftary solution 


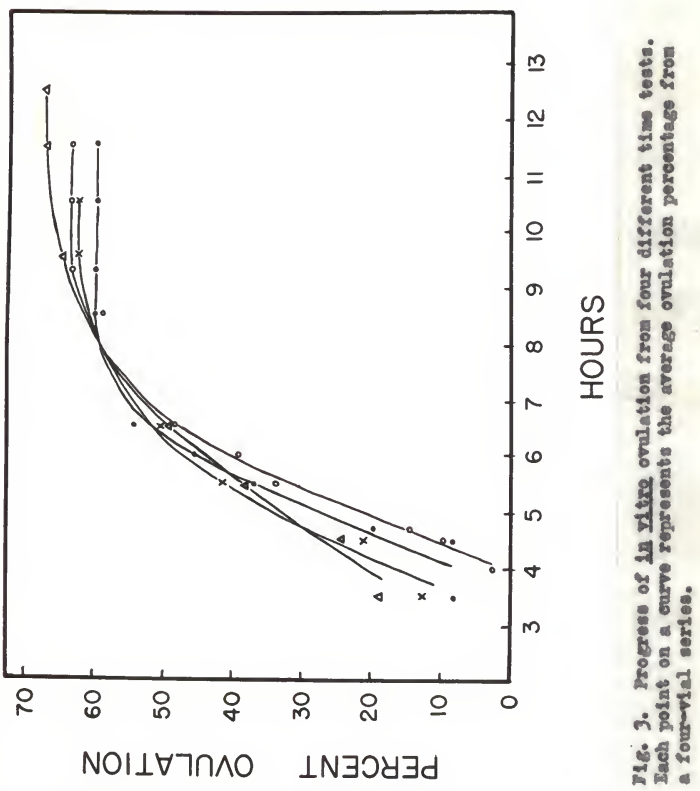




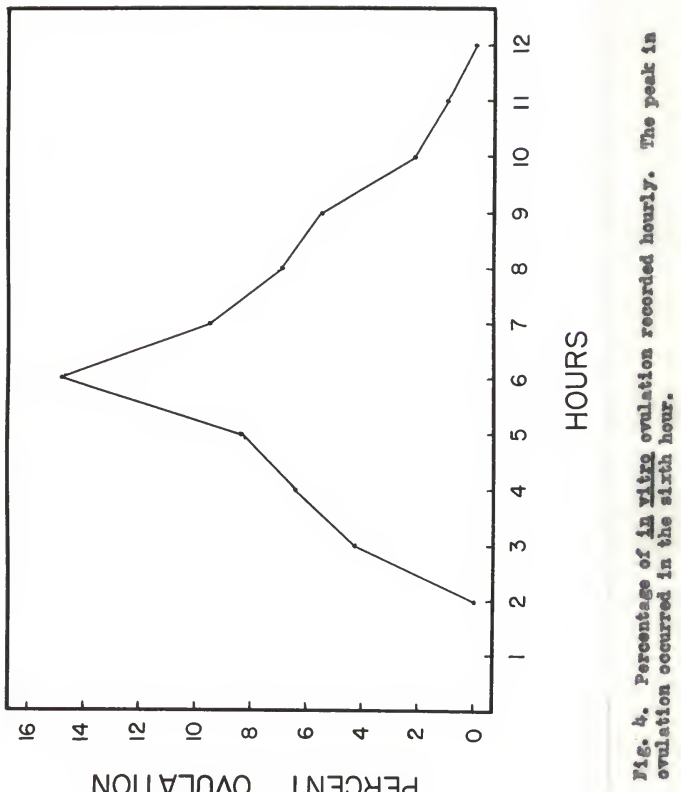




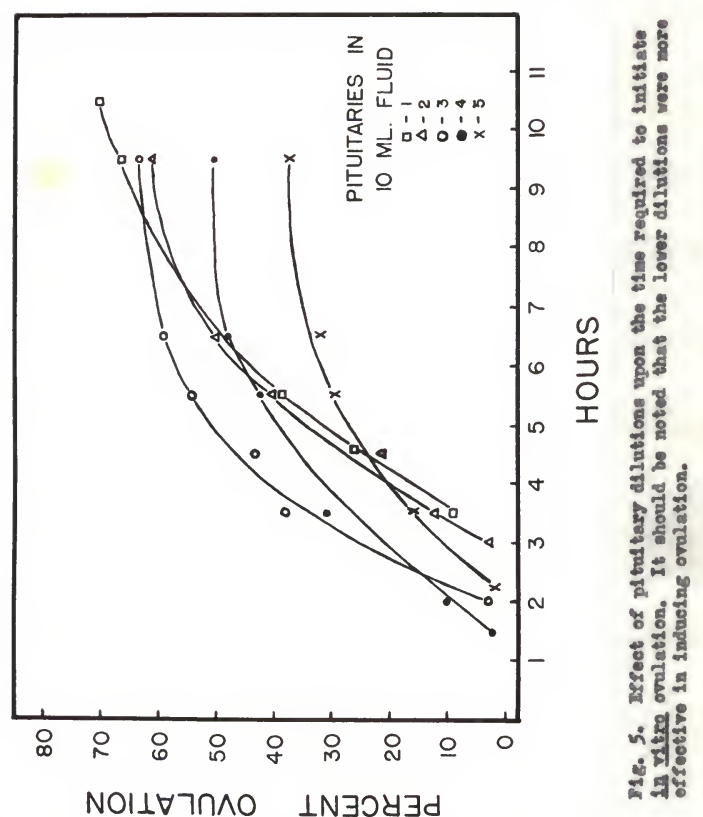


Int tiated the ovulatory process in one and one-hall hours, the threegland solution in two hours, the five-gland in two and one-fourth hours, the two-gland In three hours, and the ono-gland in three and one-haif hours. Thus it appears that, up to a point, higher pltultary concentrations initiate the ovilatory response in less tiat. Bowever. at the IIve-gland level, the inftiation of orulation was sonewhat retarded. Thls action 1 probably due to the inhibitory stimalus found in higher concentrations of pltultary (see section on P1 tuitery Dilutions). Pltultary concentrations of one, three, two, four, and IIve anterior lobes produced in order, highest to lowest final percentages of orviation.

Effect of IIght Opon In Vitro Ovulation

Since experiments vere to be carried on at all hours of the day, It seemed necessary to deterulne whether the presence of Ilght affected in vitro orulation. A standardized pltustary suspension was prepared for an elght-vial series, esch vial containing the equivalent of one-half of an anterfor lobe in $10 \mathrm{ml}$. of normal solut1on. The ovary from a single ferale was cut into small pleces under a Wratten Safelight (Series OA) in a photographle darkroor. Four control vials vere left in this room in absolute darloness. Four experimental vials were removed to an adjacent room of the sane teamperature $\left(78^{\circ} \mathrm{C.}\right)$ and there exposed to the $11 \mathrm{ght}$ of a 100 watt 
bulb placed 12 inches fros the vials. White paper was plsced back of the vials to throv reflected light to all parts of the suspended pieces of ovary. Each set of vials was placed in a large shellow pan of water so that no signiflcent temperature fluctuations would take place.

The results from this experiment are shown in Table 10. A statisticel analysis was made of these data and the difference in ovilation percentages was found to lack stat1stical signfleance $\left(t .=1.01, P_{0}>0.05\right)$. It was therefore concluded that 11 ght plays no signifleant role in the stimulation or inhibition of the ovilation process in vitro.

Iffect of Temperature Upon In Vitro Ovulation

wright (1945) conducted a test to determine the effect of temperature on in Vitro ovalation in Rana plpiens. He found that In vitro ovralation took place between temperatures of 170 and $32^{\circ} \mathrm{C}$. . Wh th an optimum at about $22^{\circ} \mathrm{C}$. and that no ovvlation occurred at $12^{\circ}$ or $37^{\circ} \mathrm{C}$. He did not, however, establish defini te temperature 11uts for the process.

Sour experinents were undertaken to test the effects of temperature on in vitro ovulation in Scaphlopus holbrookd. Each of the experimental vials contained the equivalent of one-half of 


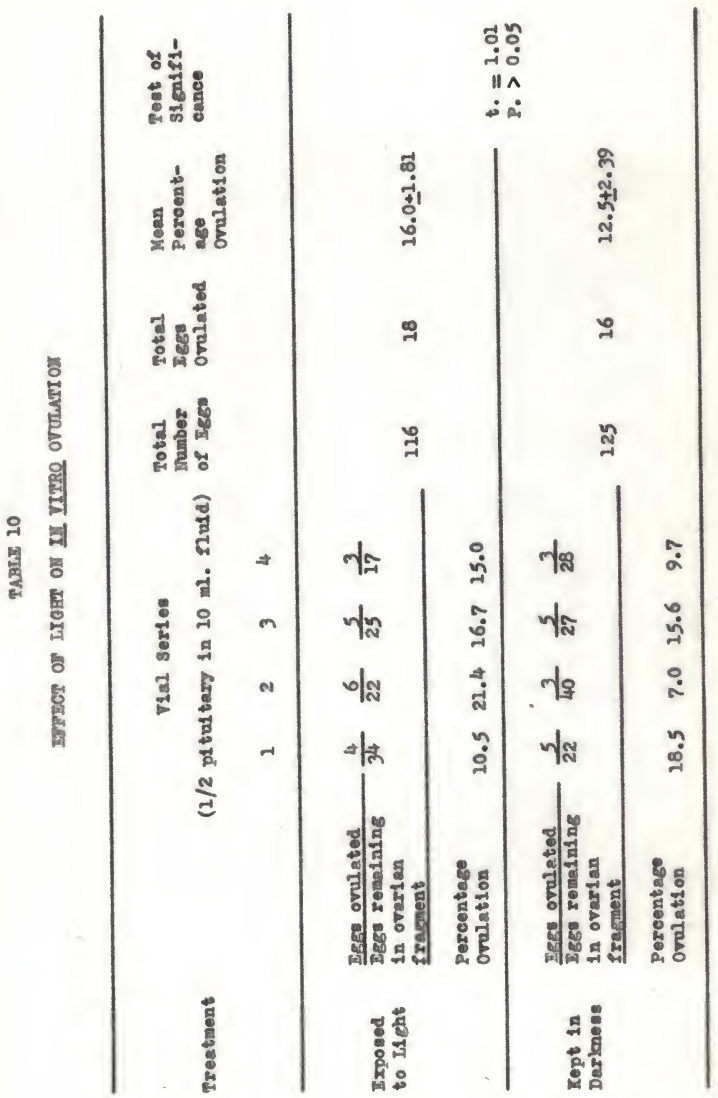


a pltuitary in $10 \mathrm{ml}$. of Holtfreter's solution, and a single ovary donor was used. Three refrigerators and an incubator were used to achleve the desired range of temperetures. Before 1mmersing the ovarian fragments in the pltuitary solutions, the vials vere allow ed to attain the temperature at which they were to be malntained throughout the course of the experiment. The first experiment was designed to glve a wde range of temperatures $\left(4-35^{\circ} \mathrm{C.}\right)$. In order that approximste temperature 11 ndts wight be ascertalned. Subsequent experinents were refined to deternine the exact upper and lower limfts, as well as the optlmun temperature.

The Individual and mean result for each temperature class are presented in Fable 11. From these dats 1 may be concluded thet in vitro ovulation occurs between $10^{\circ}$ and $30^{\circ} \mathrm{C}$. with an opt1 anus at about $24^{\circ} \mathrm{C}$. The percentage of ovulation 1a reduced at both lower $\left(10-20^{\circ}\right.$ C.) and ht gher temperatures $\left(28-30^{\circ} \mathrm{C.}\right)$, and complete Inhibition occurs at $9^{\circ} \mathrm{C}$. and at $31^{\circ} \mathrm{C}$. A temperature curve based. on these data is show in rigure 6.

Effect of pH on In Vitro Ovulation

Rondell (1953), using Rana nipiens, found that in Vitro ovilation took place between pH values of 6.6 and 8.2 , wh complete Inhibition at 6.0 . Very 11 ttle $1 \mathrm{~s}$ mom concerning the effects of 


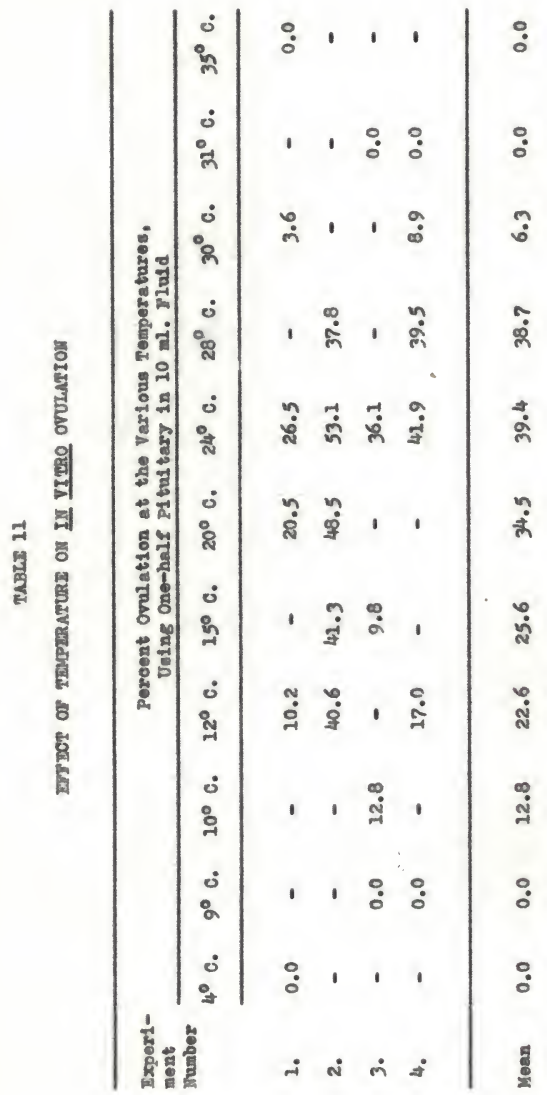




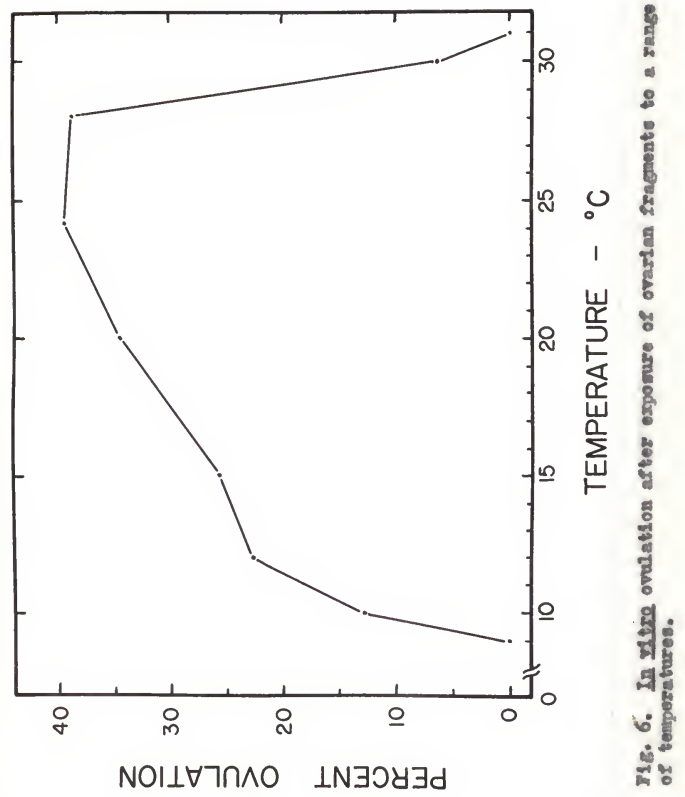


pH upon the blocatalytic action of hormones. Since the buffering capacity of Holtfreter's solution is slight, it seemed 1mportant to determine the influence of $\mathrm{pH}$ on the ovalation process in vitro.

Two biological buffering arstem were enployed. The 21xst mas a veronal acetate buffer (Gortner and Gortner, 1949), prepared by adding 14.71 gram of sodiun veronal and 9.71 gram of sodiun scetate trihyirate to $500 \mathrm{ml}$. of dist1lled vater. To a given anount of this solut1on, various quantitles of $0.1 \mathrm{M}$ BCL were sdded, producing a pR range from 3.01 to 9.42 . Using this buffering system, in vitro tests were run at $p H$ values ranging from 4.01 to 9.42. Two vials were used for each pif value. The pitultary homogenate was added to the stock solution of veronel ecetate. Both experinental and control vials contalned the equivalent of one-hels of a pltuttary in $10 \mathrm{ml}$. of buffer or Foltereter's solut1on, respectively. A second control was used in which the Fiels contalned only Boltireter's Pluld wh no pituitary.

AII experimentel vials (those wth buffer and pltultary) geve negative results, as did the control blanks containing Boltfreter's solution w thout pitultary. The control vials with pitultary ovulated normelly, hovever, with a mean ovulatlon percentsge of 38.7 percent. Thus ovulation was inhtbited by this particular buffer system, probably because of the nercottc effects of the sodiun reronal, which is a berbiturate derivetive. 
since veronal acetate obviously could not be used as a buffer In these experinents, a phosphate buffering system was prepered in which the pir was aljusted by varying the ratlo of nonobesle sodivi phosphate $\left(\mathrm{IaH}_{2} \mathrm{PO}_{4} \cdot \mathrm{H}_{2} \mathrm{O}\right)$ to dibasic sodium phosphate (Ias $\left.\mathrm{HPO} \cdot 7 \cdot 7 \mathrm{H}_{2} \mathrm{O}\right)$. after Gomor1 (1952). In prelininary teste ovulation was found to proceed normally at $0.1 \mathrm{M}$ and $0.0 \mathrm{M}$ concentrat1ons of the phosphate buffer, but, at molarities of $0.007 \mathrm{n}$ and lower, all eggs were cyto1 zzed alue to the hypotonicity of the buffer solution. Since Holtfreter's solution has a molarity of $0.0638 \mathrm{M}$, a molarity of $0.07 \mathrm{M}$ was malntalned for the phosphate buffering syotem, but the ratio of monobesic to dibale sodiun phosphate was veried to produce for the tests a pF range of 5.9 to 8.9. For a further check, each solution was tested with the Becknan pli moter after the addition of the pitultary homogonate. The pitultary homogenate was added to a mall quant1ty of the dibasic solution and this was distributed equally anong all viels. Additional dibasic eolution was added to those T1als requiring higher ratios of the dibalc to monobaele phosphate.

The results fron these I1ve tests are recorded in Table 12. and are presented in the forn of a curve in Figure 7. From these findings it 1 s evident that ovilation occurs over a relatively wide range of hydrogen Ion concentrations wh a peak of activity at a pil of 7.3. It is inhibited, however, belov 6.5 and above 8.5 . 


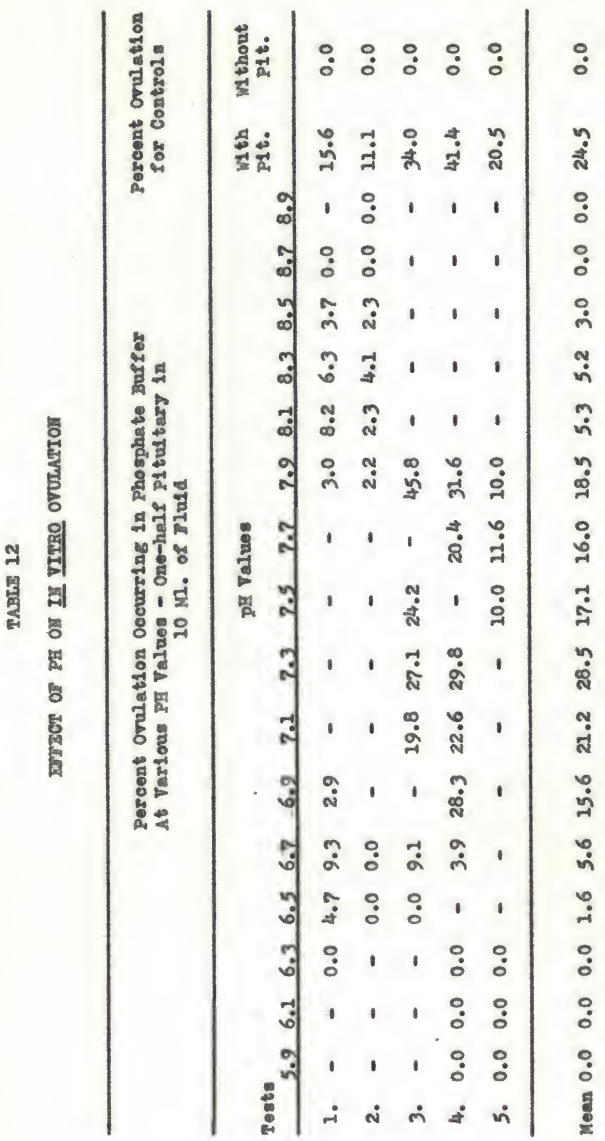




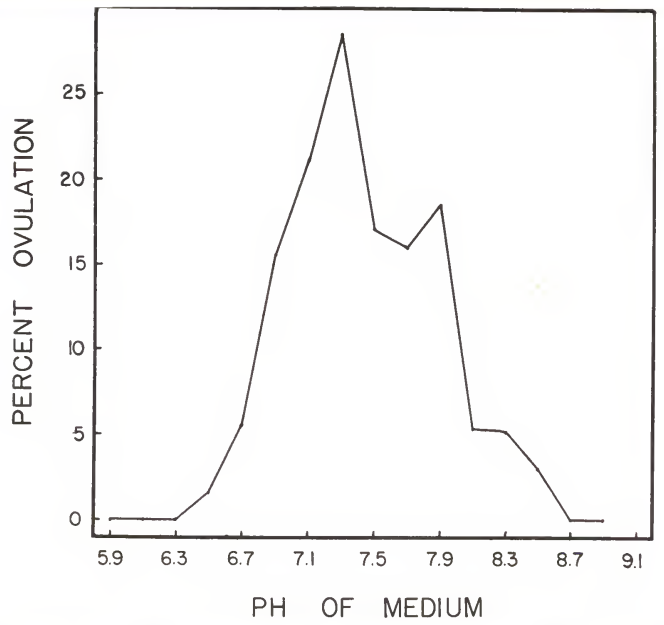

11G. 7. IPfect of hydrogen lon concentrations upon in fitre ovilation. Merdmal ovilation was obtalned near the point of neutrels ty (7.3). 
Iffects of Feteroplastic PItutary Vateriels Upon In Vitro Ovilation

Wolf (1929) conducted the flrst experiments on the Induotion of ovulation in Aaphibla by the implentation of pituitary glands. Since that date numerous sinflar experlments have been performed using both honoplastic and heteroplast1c tissues. Creaser and Corbran (1939), after revieving the 11 terature on incueed ovilation anong Anphibla, brought forth the folloving 1aportant generall zations: 1) that Amphibla and other classes of vertebrates respond read1Iy to very al1 ght amounts of homoplastlo p1tultary nateriala: 2) that the effectivenean of a gonadotroplc hormone from a forelgn species tends to vary directly w th the phylogenetle affintty of the donor and reciplent species: 3) that a qualitative specificity exdsts in gonadotroplc hormones; and, 4) thet the variation in gonad gpociflcity botween wdely seperated donor and recipient species way be great enough to load to an epparent ineffectiveneas of the hormone.

Because of the correlation betieen gonadotropin speclelelty and the phrlogenetic relationshlp, a study we ande of the effects of heteroplastic pituitary neteriels upon the in vitro process. Since the size and hormone t1ter of the varlous pituteries vere quite variable. 1t vas 1mpossible to ut111 ze the resulta for quantitetive comparisons, and they are therefore 11 sted simply as positive or negative. It is $11 \mathrm{kel}$. that this ovalatory technique inght be used for precl se quantitative measurements of hormonal homologles. 
An attenpt was made to secure representative pituftary donors from the marity of vertebrate classes. Particular attentlon was given to the relationshipe within the Amphibla. The comparative regults are recorded in Table 13, whlle a dagramnatic phylogenst1e tree shows where the alsterent effect took place (rig. 8). Control V12ls, esch contalning one mele spaderoot pitultary suspended in $10 \mathrm{ml}$. of Nusd, were uned in all 1nstances. From thls studg it is seen that the 1n 7litre ovulation mochend an is quits senal tive to hsteroplastio pltuftary 1 mplants. Pl tud tary terlals from amphlbians, reptiles, b1rds, and most mamels evoked ovalation In vitre. Onls the pl seine pitultary, swne gonadotrople fraction, and human pregnanoy urino palled to induce ovalation. Thus, it is evident that pituitary materlals Irom Amphibla and higher phylogenetic esategorles stimulate the ggs of Scanhloras to ovilate In v1tro. 


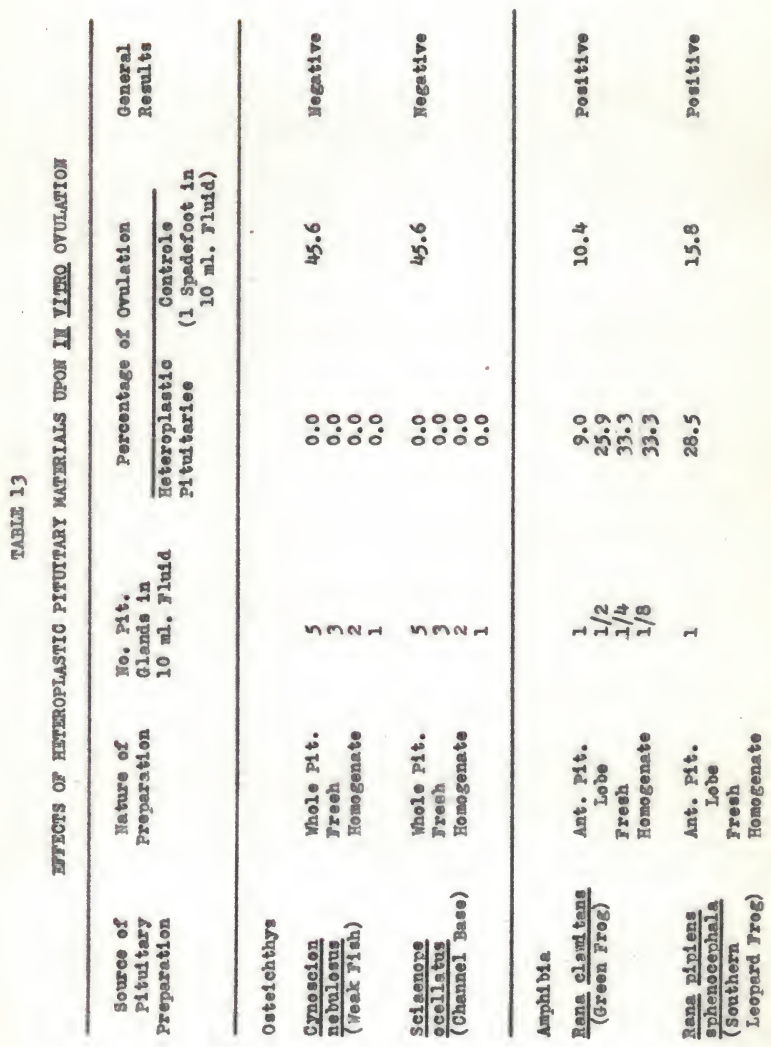




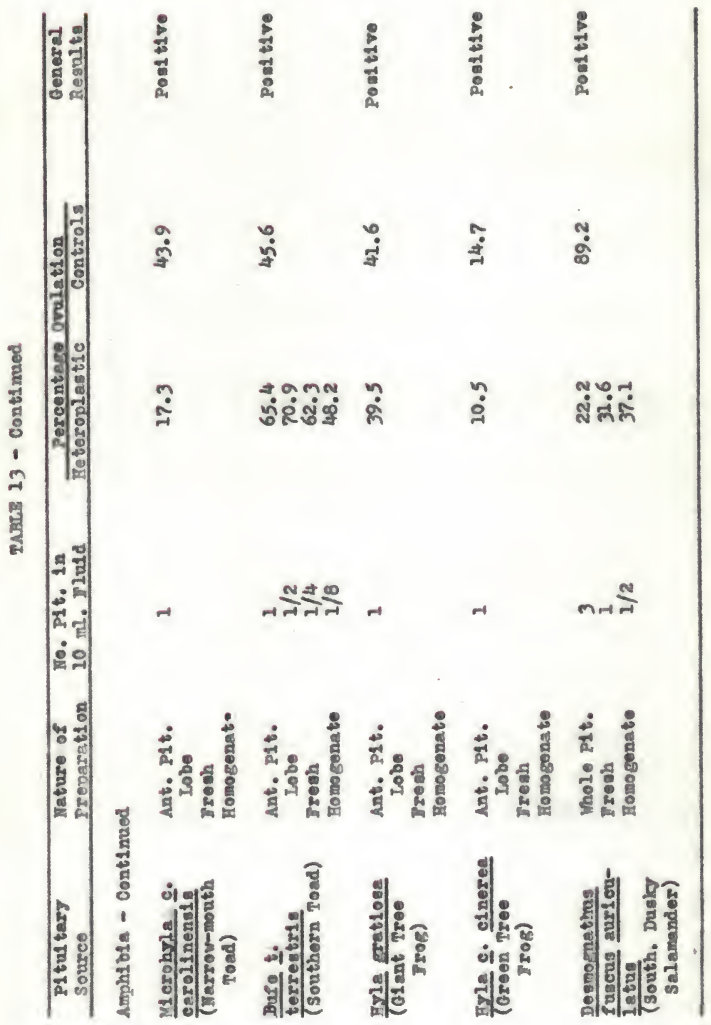




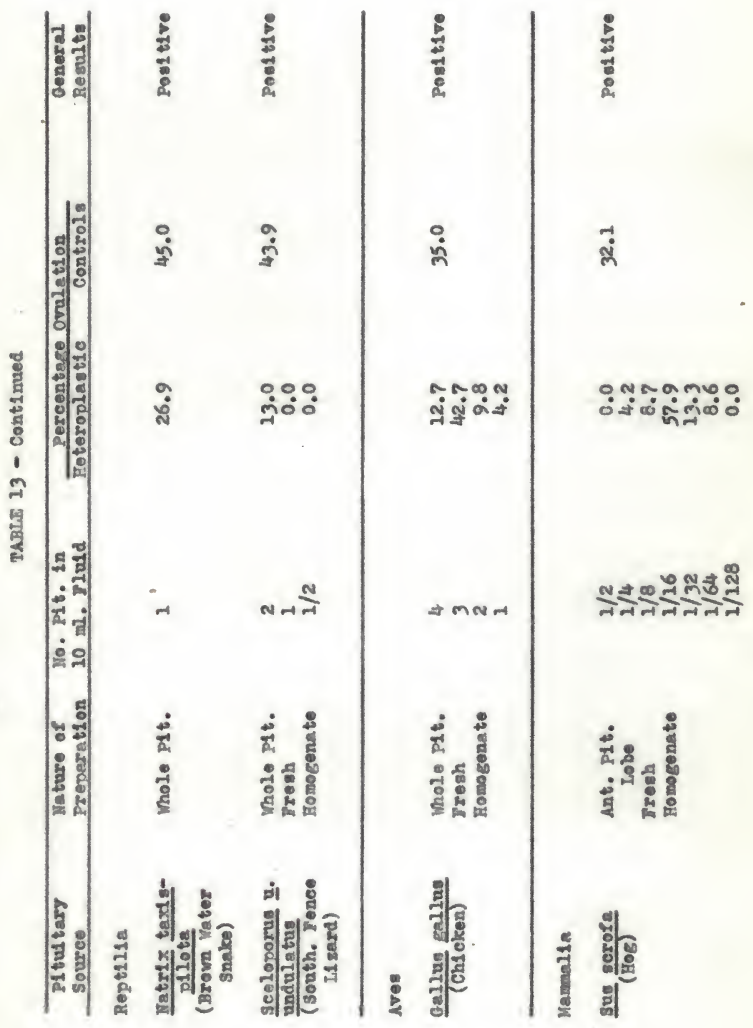




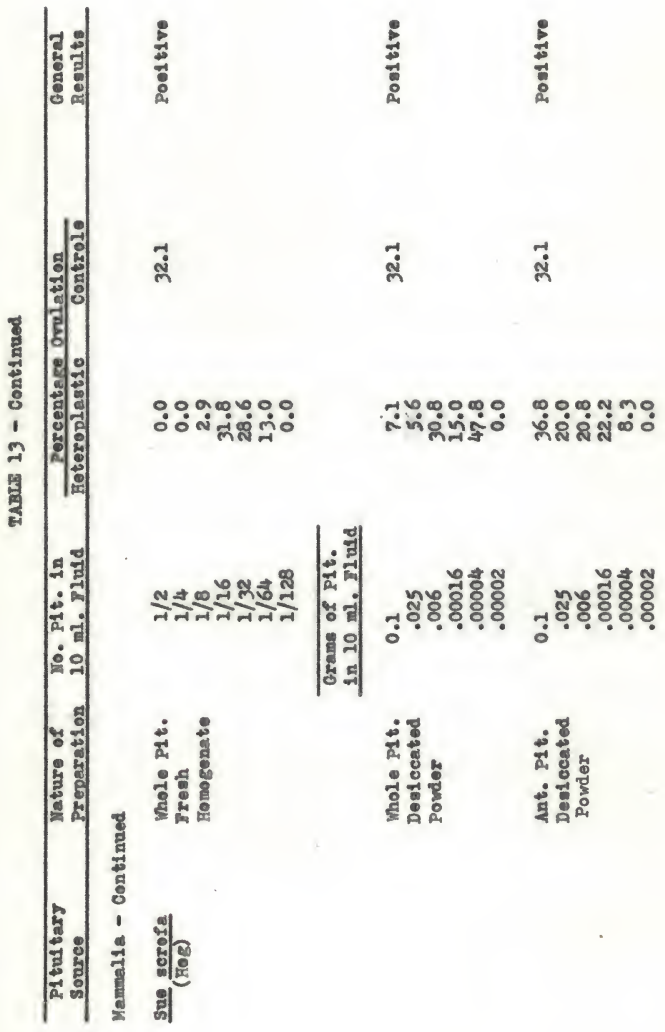




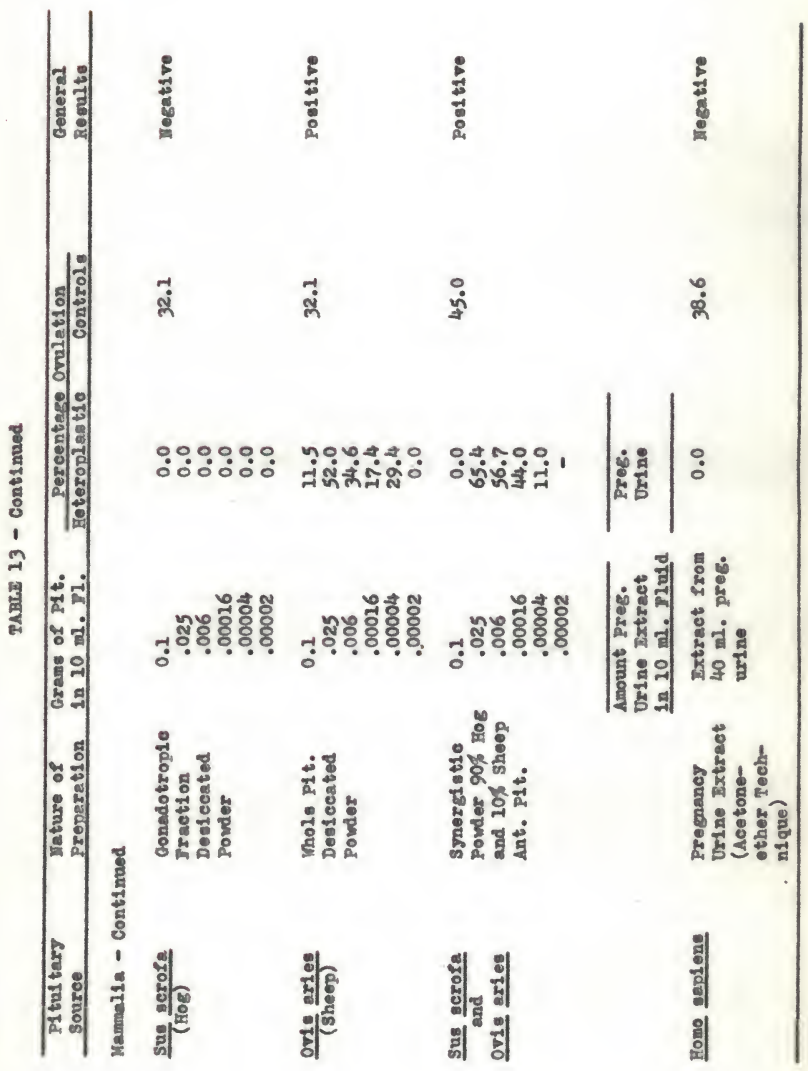




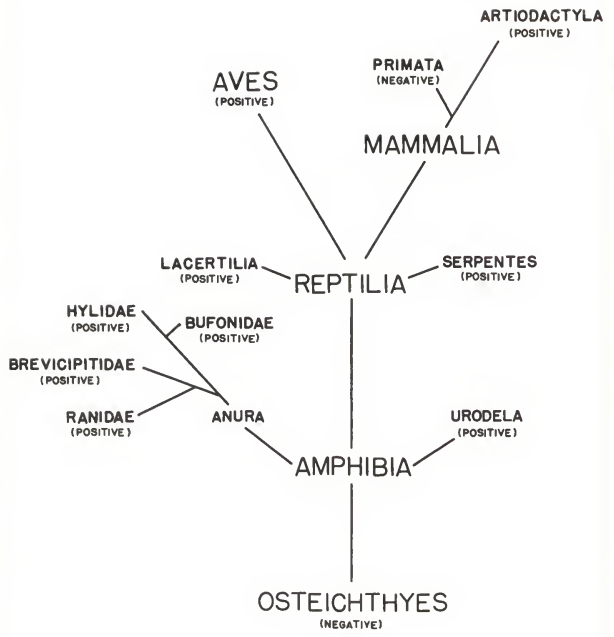

r16. B. Dlagramat1e phylogenut1e tree showlng the general effeot of varloue pitustary naterial. upon in Itro orulation In Scaphlorens helluroold. 


\section{Phrotoloetcel and Ecoloetcel Relations to the} Breeding stimine

It 18 generally recogni sed by herpetologists and natural1 sts that, throughout its range, the eastern spadefoot toad (Scanhtones holbroold) breeds in temporery ponds during the wermer months of the year, folloving perlods of ercees1ve ratueall. In fact, the principel breedine cue recogat ged by this gpecies seeas to be excessive preclpitation, providing the elr and fround are not near Ireeslng temperatures.

An excellent Insight Into the ocologicel requiresients and breeding behavior in the genus Seaphtovis is given by Brags (1945). He points out that all epedefoots exhiolt a xerlo pattern of breedIng characterlsed by 1) lack of a definite breeding season, 2) use of temporary whter only. 3) breeding behavior in nature inttiated only by the coming of rain, and 4) males and females attracted to a chorus by the loud volces of males. Bragg further mentions that the eatern spadefoot seens to be stimulated by large amounts of rainfall, rather than by the violenee or rate of $f$ all as is characterlstic of S. bomblfrons. ․ hammond1, and S. concht. Ho also points out that low temperatures may inhibit breeding by nembers of ths genus.

Perhaps the best work deeling 1 th the breeding of the eastern spedefoot toad is that of Ball (1936). He states that in order for 
breeding to occur, "the ground tempereturss mast have risen above $2.5^{\circ}$ C. In the stratun occupled by the toads, and euffielent rain mat have fellen to gaturate the so11."

Iron the I1tarature and through personal communteation, breedIng record of the padefoot were obtalned frow thirty-el ght natural1sts (Tabls 14). Record of 121 different breading choruses from locallties over the entire range were included. Data on the type of breeding pond, the time of day at which breeding occurred, preelpltation, and temperature were also given when avallable. Neather data for all rloride breoding chorues were obtalned fron the records of the Weather Jurean $(1921-1955)$. These record reveal certaln iendricent racts.

\section{Breeding Season}

The pirst record regerding the length and time of the breeding geason for the spedefoot was made by Sharwood (1897) who atated that, "the egg ars lasd anytine from April to rune." since thet the a number of workers have made statements concerning the length of the breeding season. Driver (1936) wrote that the spadefoot does not have a regular sesson for depogition of ove, but that the egse mar be lald anytime Irom Apr1l 1 to August 31. In 1936, Ball reported that the spadefoots of Connecticut bred as anly as April and as late August. Concerning the spedefoot in Florida, Carr (1940) 


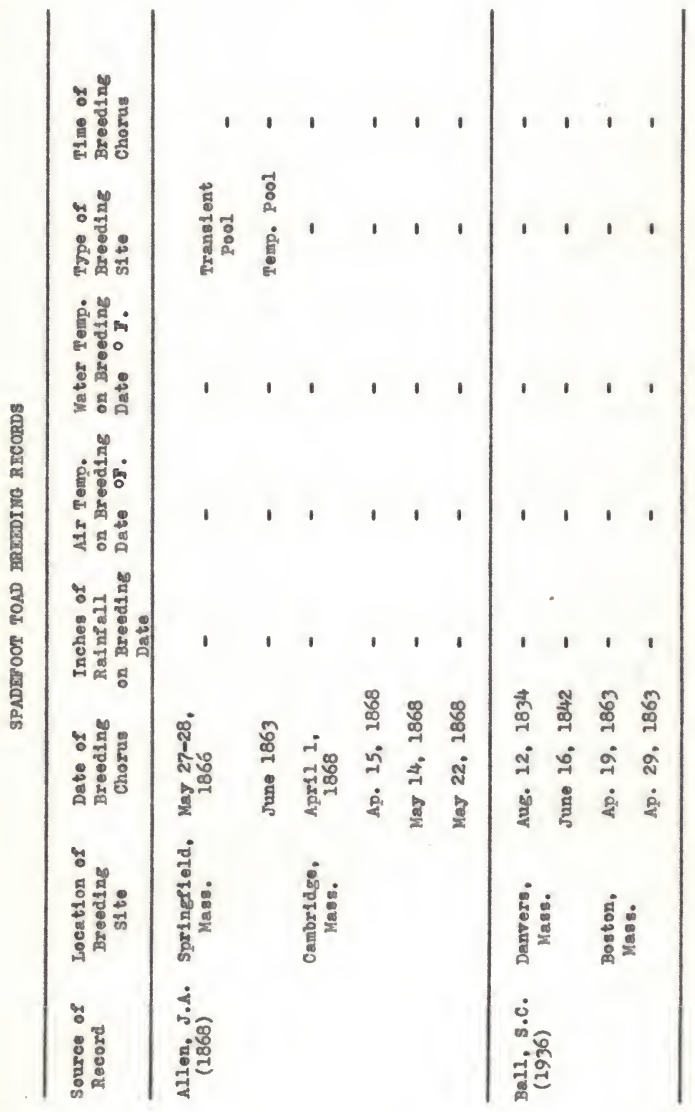




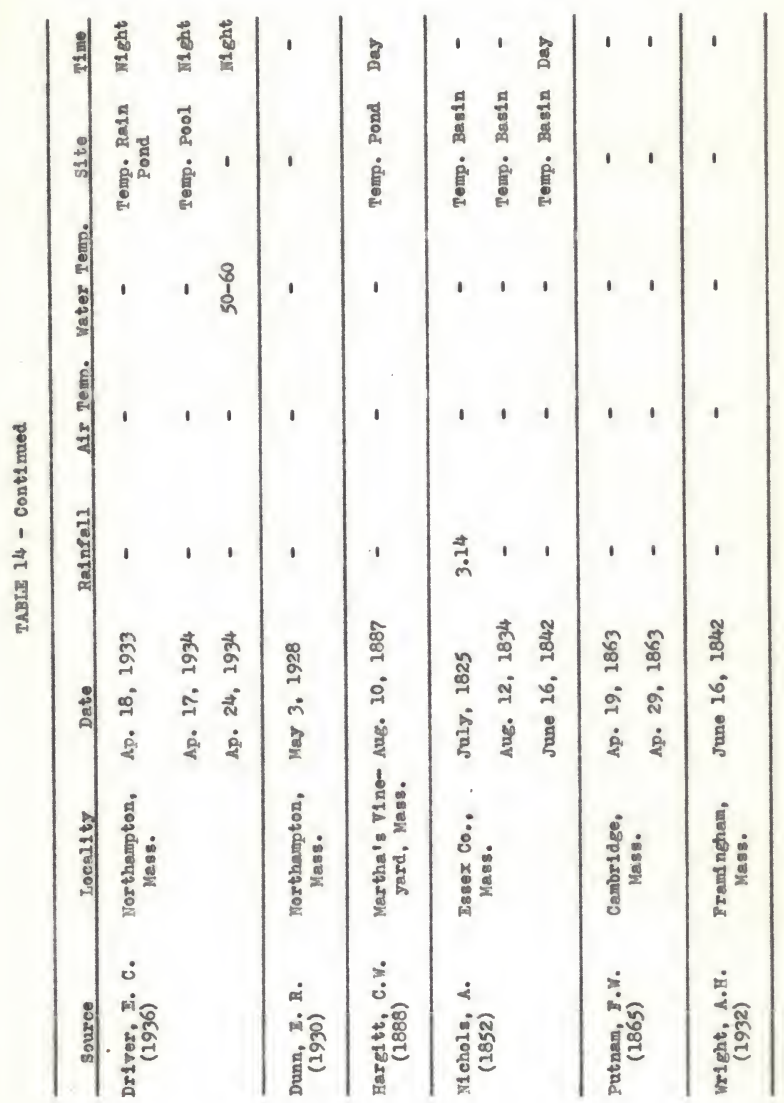




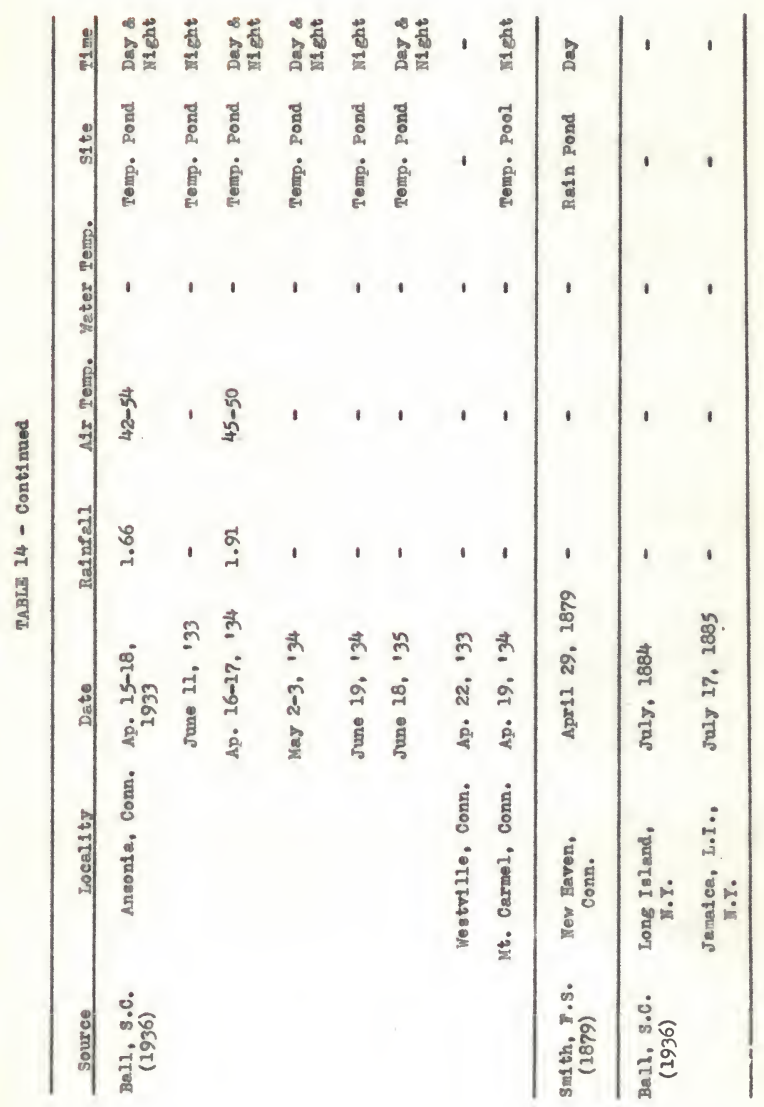




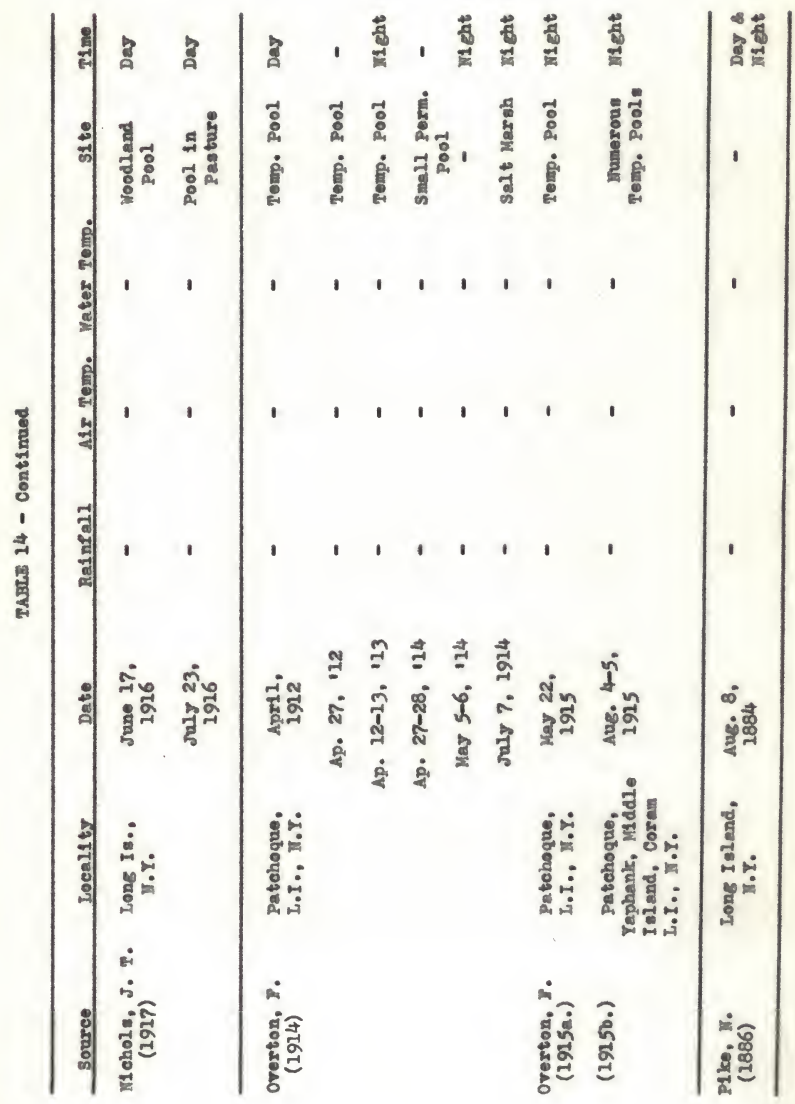




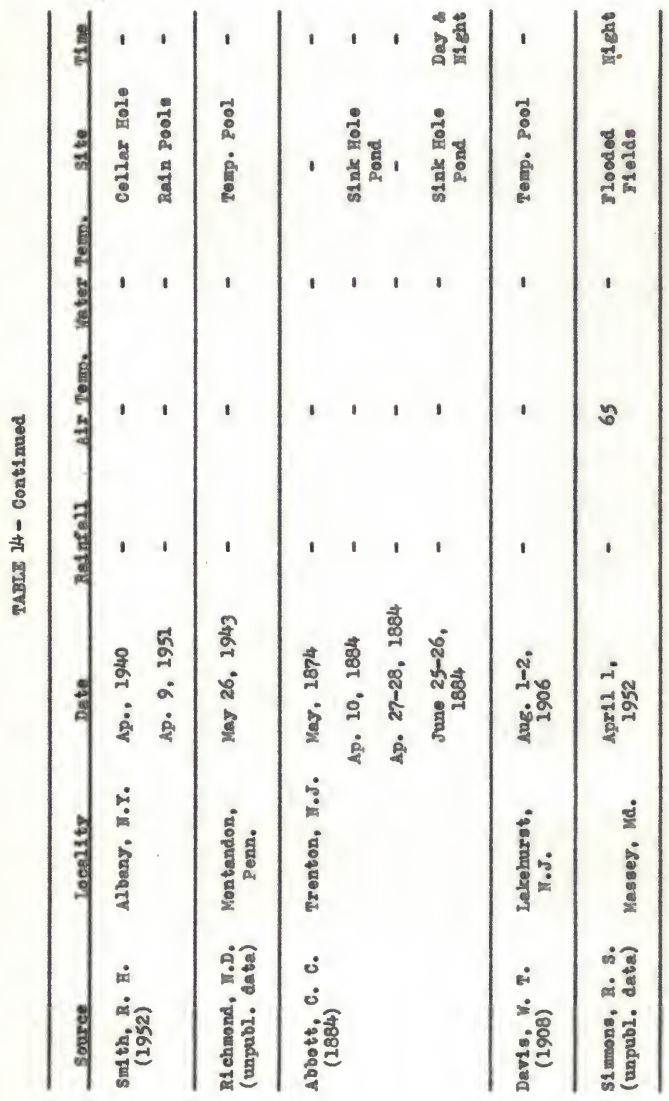




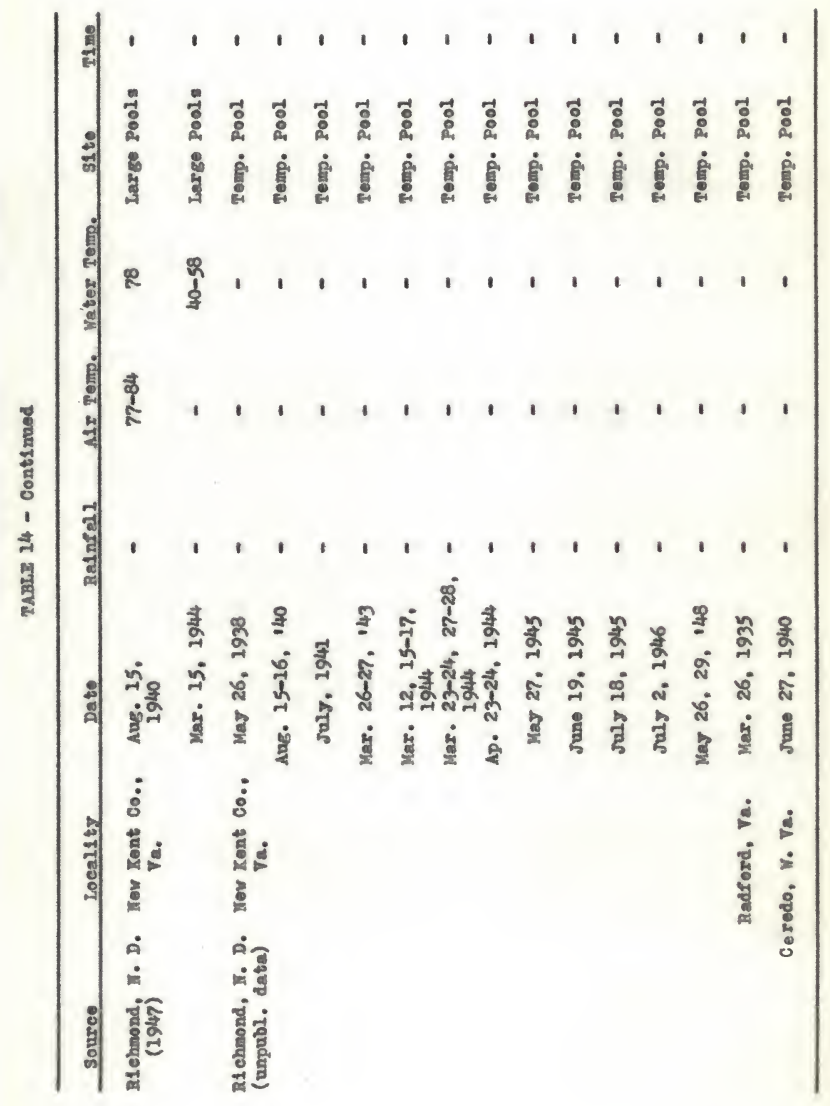




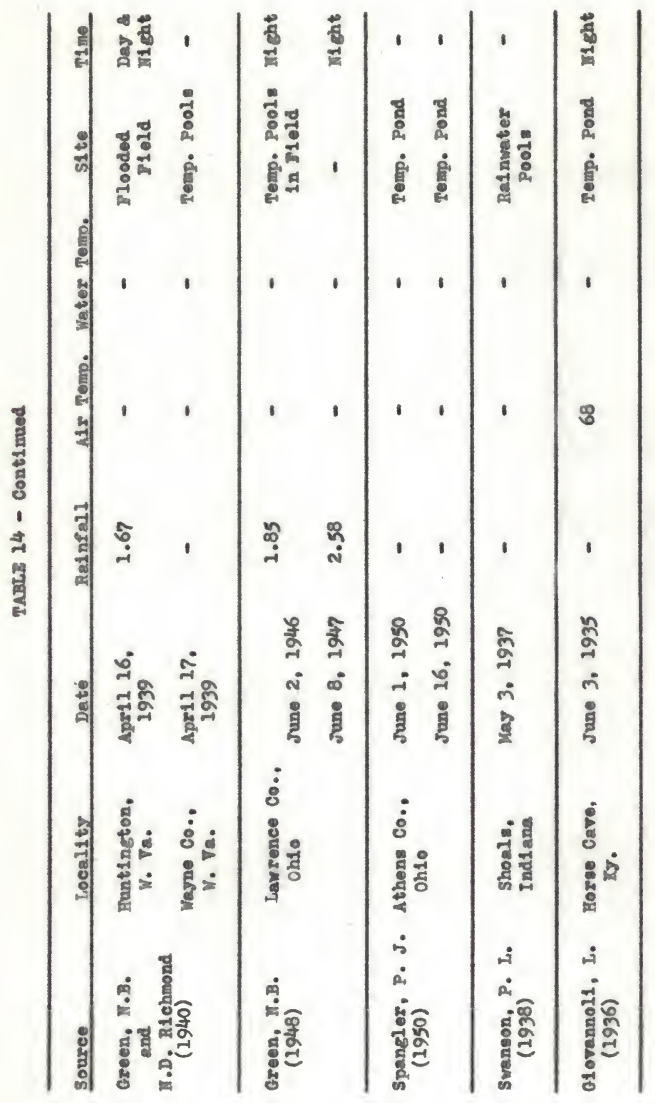




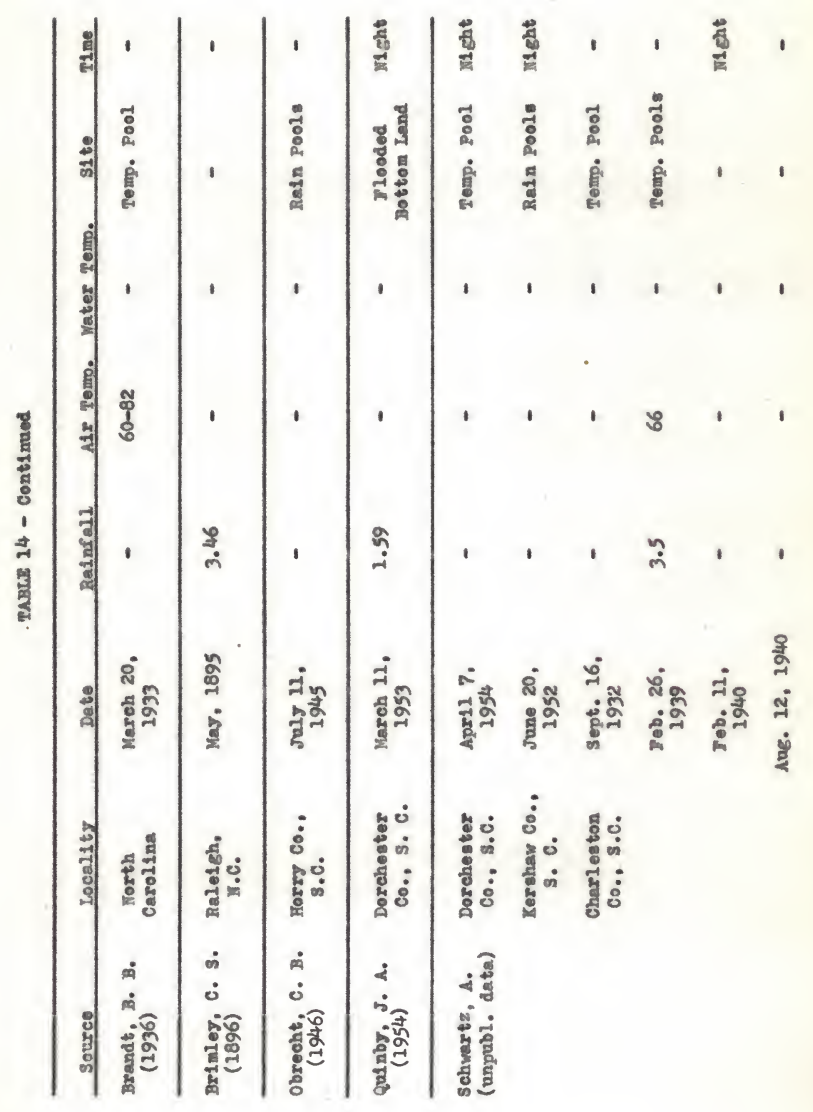




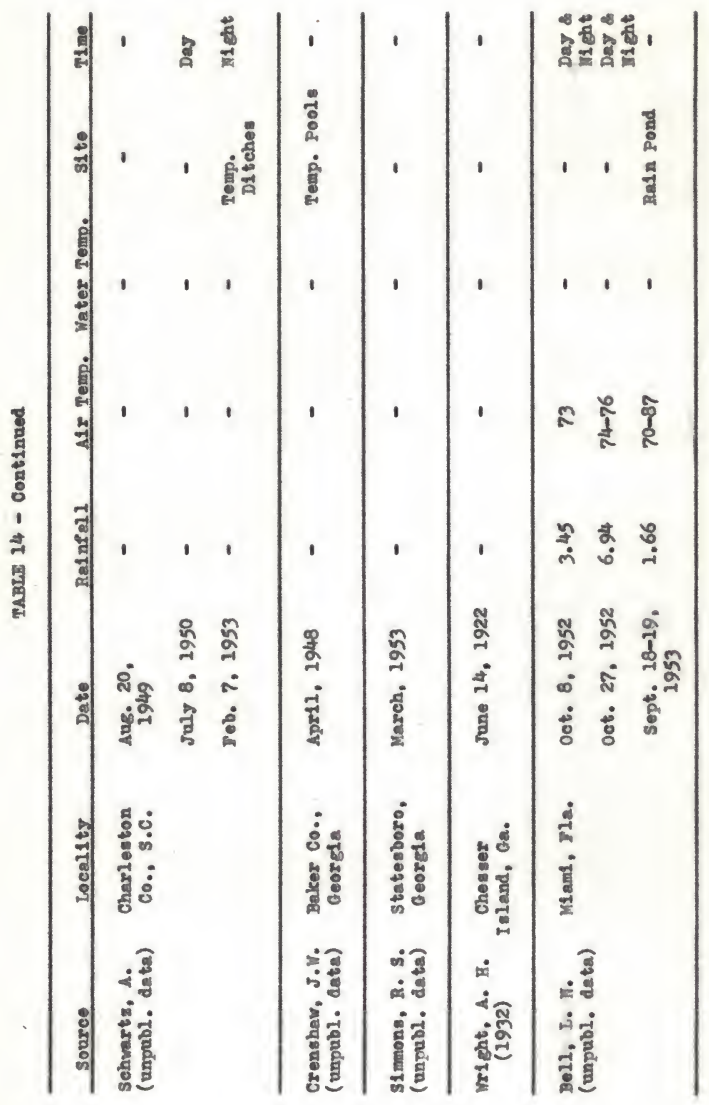




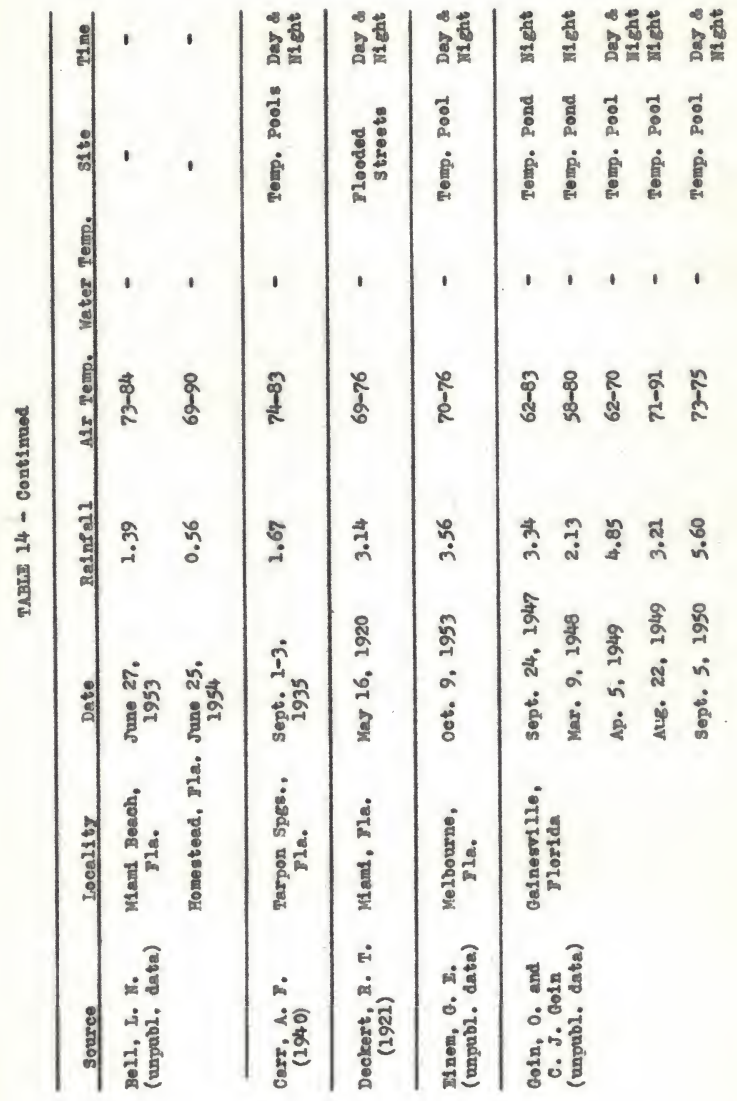




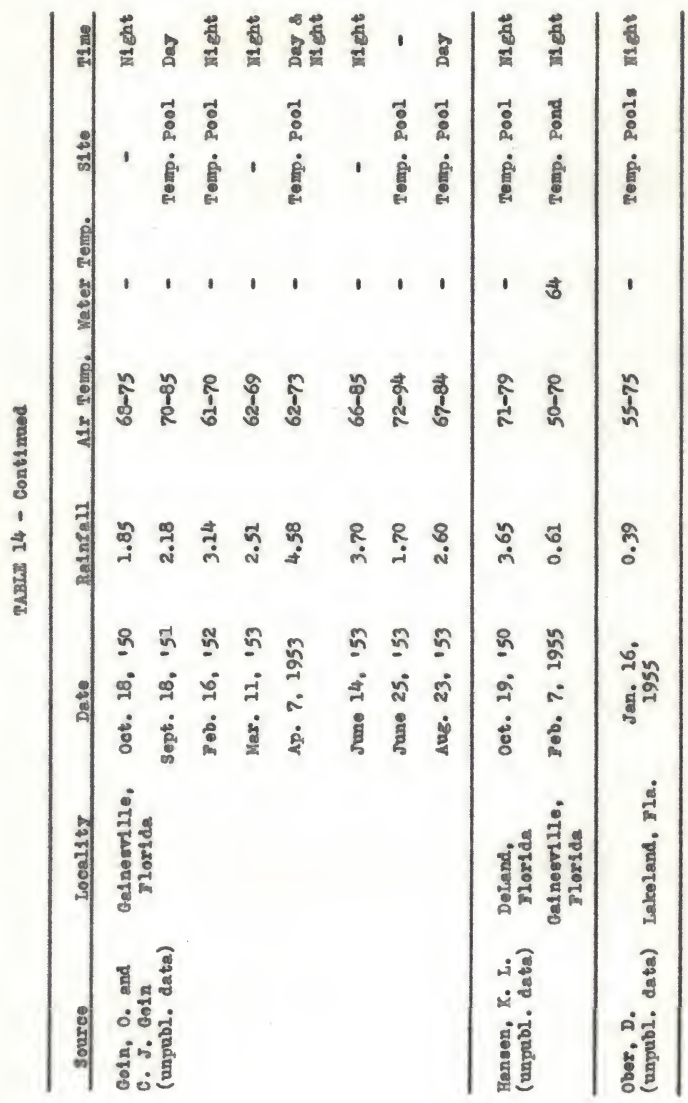




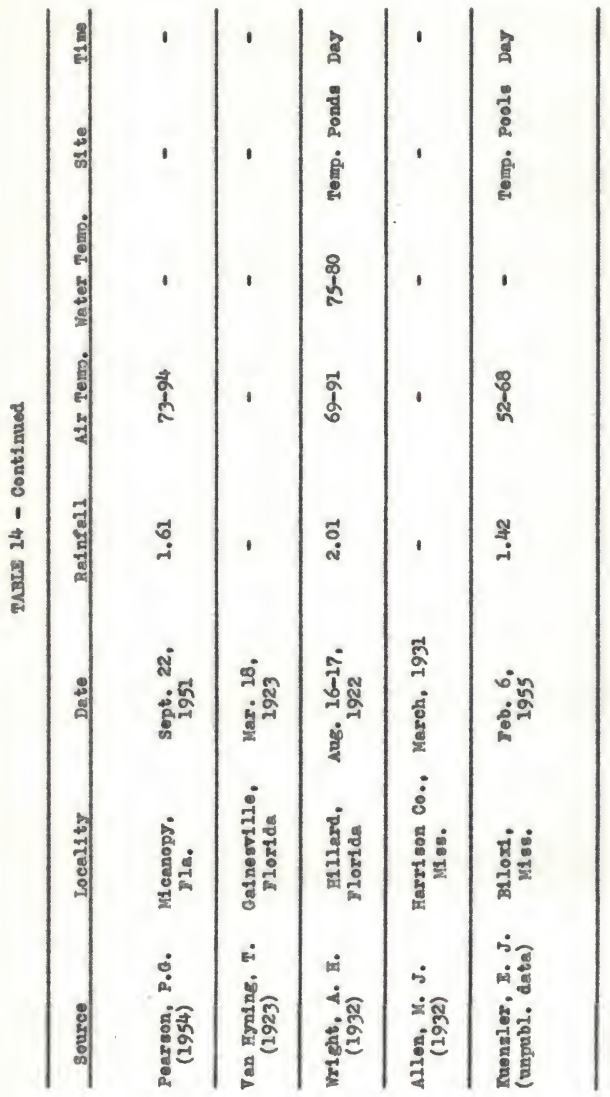


wrote that the speeles breeds "from the sumer months to made. October." Mright and Vright (1949) stated that this tood breeds from March to September at perlods of heevy ralnfall. Finally, Pearson (1954) suggested that the spadefoot does not have a partlcular breeding season In a cyelle, seasonal sense, but rather, breeds only durling or after verg heavy ralnfall.

The data In Table 14 show that Scaphiorue breeds in each wonth Iros Jemuary through oetober. Thus far, breeding choruses heve not been reported from the months of November or December, and this 1. almost certalniy due to low temperature. Then breeding dates are coneldered from a geographleal standpoint, some strildng dsferences are noted. Plgure 9 ghows the breeding records, by nonths, for toads frow the northern, contral, and southern portlons of the range. These data dre a good Insight into the pattern of breeding over the entlre range of the spadefoot but do not necessar115 present a conpletely representative plcture of breeding.

The records show that In the northern parts of the range (Mass,, Conn., and II.Y.) breeding of toads is $11 \mathrm{nl}$ ted to a five nonth perfod (Aprll to August). The great preponderence of breeding (44t percent) oceurs in April, and the eurve then Arops off sharply to the month of August ( 1 1g. 9). The toads of the middle eastern states (11.J.. Va., พ. Ve., Ohio, Ind., Ty., and I. C.) breed over a six month 

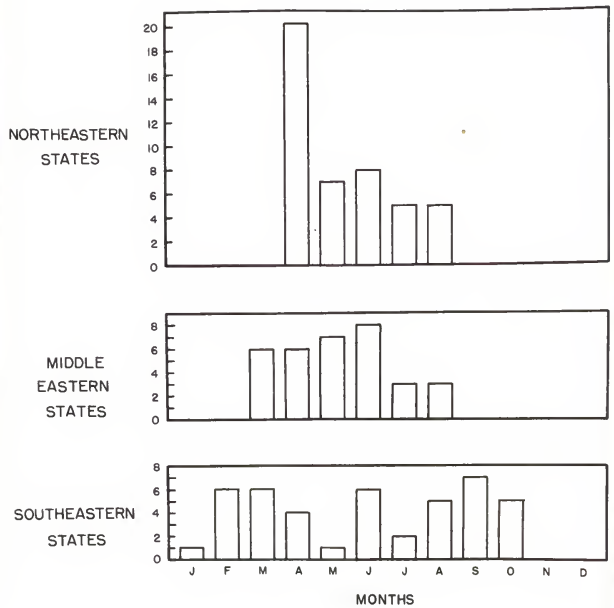

M1. 9. Monthly breeding records of eppedefoot tonds srom tho northern, centrel, and southern portions of the range. 
perlod, begluning in March and reaching a peek in June. Breeding dates for the southern group (S.C., Ga., Yla., and MIs., presented a bodal distribution, wh th peaks in vinter (Pebruexy) and Iall (September).

Breeding in Ylorlda probably occurs in any anth of the year. provlalns the environiental conditions reach an optinum state. The breeding pattern as recorded from twenty-meven choruse prewents an Interenting case. These records show that occalonal breading oecurs during January and Jebruary followed by a I1 se in the apring wt the peak in March. There is a decinge in May, but it is quite high again in June. Yor some reason, there are no breeding records for the wonth of July. A graduel Increase in breeding takes place In August, Septenber, and October wh the mode for the entire rear attained in september. ( 1 G. 20).

\section{Prectpitation}

The majorlty of naturalists state thet spedefoot breeding is associated wth beary ralnfall. Ball (1936) wrote, "Wara weather alons does not ellc1t the gpring nating regponse; there rast be heavy raln." In 1936, Driver steted, "Appsurently the only opportunity for the development of a ney generation of spadefoots occurs when wore than average ralneall comen in late spring or carly summer." 


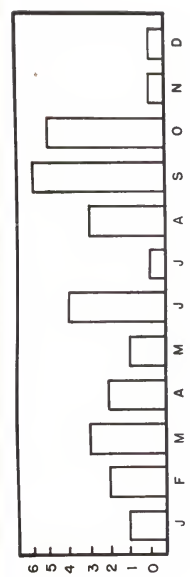

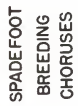

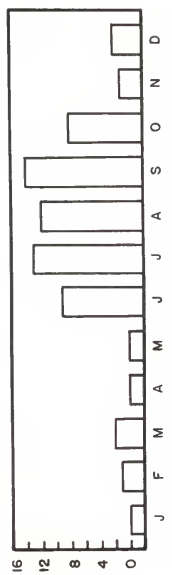

5

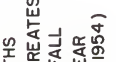

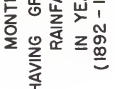

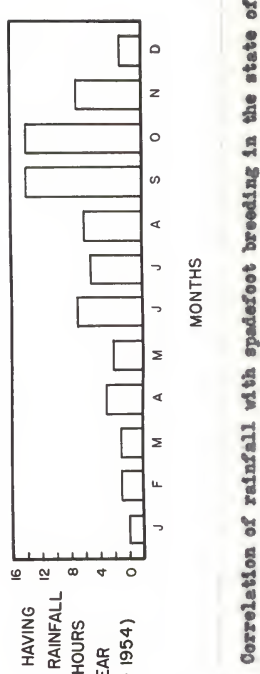

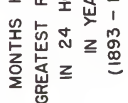


Conner and B2ack (1954) reportod thet, "Scerohlomus holbroold usuelly breods curing perlode of two to three dags, its reproductive ectivitles belug in large rain-1nttiated." When the amounts of preclpltation asmoclated wth all of the breeding records were evereged, a mean value of $2.69 \pm 0.21$ 1nches ves obtalned. The amount of rainfall associated wth breeding ranged 2 rom 0.39 to 6.94 inches.

In the state of Mortda en Interesting relationshlp exd sts between rafinfall and gpadefoot breeding. The fact that, $90 \mathrm{far}$ at recorde are concerned, the greateot concentration of breeding in Jlorida has occurred in the nonth of September may be correlated Wth rainfell (J1E. 10). Between the rears of 1892 and 1954, the hoavlest total proclpitation for any single month of the geax. occurred moot frequently in September, and Irom 1893 to 1954, the months whioh had the greatest ralnfall in a tventy-sour hour period vere September and Oetober. A further check of the elf matologleal records at the various breeds 200 llties over rlorida, showed that P1fteen of the twenty chorusee occurred on the dey of the month having the greatest precipltation. In their report on the ellmate of Florida, Mitchell and Insign (1928) wrote that hurrlcanes and tropleal atoras may be expected durling the late mumer and enriy 2ell. Five of the eleven choruses whlch have been recorded in the late sumer and early autumen in Florida took plece during or follow Ing hurrlcanes. It therefore appeare falrly certaln that the August- 
September-october increase in breeding is correlated wh the hurrlcenes whlch come st that tine of tho gear.

\section{Temperature}

Precipltation is abeolutely eseential to breeding by the spedefoot toed, but temperature condltions wat also be ferorable. Bragg (1945) reperts that spadefoot breeding is inhs bited by $10 \%$ temperature. Fe shows that breedine by $\underline{s}$. bomblfrons ueually occurs at temperatures above $52^{\circ} \mathrm{F}$. . al though males may cell at a temperature of about $48^{\circ} \mathrm{s}$. (This terperature 1imt if in alnost perfect agreenent wth the temerature livt $\left(50^{\circ} \mathrm{r}.\right)$ for in vitro oviletion In the eastern ppadefoot.) Derller, Bell (1936) hod asserted that breeding took place only after the temperature of the ground occupled by the toads hed rieen above $36,5^{\circ} \mathrm{F}$. Ho edintted, however, thet no spadefoots bred in 1933 or 1934 unt1l the alr temperature hed risen to $46^{\circ}$ and $49^{\circ}$ F... reepectively.

The tempereture 11 its fust nentloned are in close egreenent Wth sone records gathered by the witer nes Galnesvilo, rlorlda. In Jemuery, 1955. the Gatneovi11 Weather Station roported precipltetIon and minimumarimum temperatures as follows: January 22) 0.33 Inches, $47^{\circ}-62^{\circ} \mathrm{J.1}$ 23) 1.97 Inches, $45^{\circ}-48^{\circ} \mathrm{F} \cdot \mathrm{I}$ and 24) 0.45 Inches, $38^{\circ}-41{ }^{\circ} \mathrm{F}$. On the nights of Januery 23 end 24 , a thorough 
reconnal saance was made of areas known to be 1 nhablted by toed populat1ons, but no breeding was found. Alr temperatures of these areas were $40^{\circ}-41^{\circ} \mathrm{Y}$. on both nlghts. Sufflelent ralnfell had fallen by the nlght of Jamuary 23 to form numerous temporary ponds In the lower Plelds, basins, and roadside ditches. However, the Low temperatures inhibited breeding on both nights. That temperature was the ilniting factor is almost certain, since toads of this area bred on February 7 after less ratniall than on the previous January dates. However, the temperature had risen about $10^{\circ} \mathrm{r}$. Wth a minimummaxdmum tempereture of $50^{\circ}-70^{\circ} \mathrm{r}$. The vater temperature In one of the breeding ponds was $64.5^{\circ} \%$. On March 28 and $29,1955$. a total of 1.28 inches of raln fell. The mfinmenterature on these two cars ves $37^{\circ}$ and $33^{\circ} \mathrm{r}$. , regpeetively. A trip was rede to the same areas whloh had breeding choruses in Jobruary. No breeding choruses were heard. A quick reconnal sance of the plelds adjolning the temporary pools showed that no toads hed emerged from their burrows. Again, temperature eeemed to be the factor $11 \mathrm{nt}$ ting breed1ng. Sumeristing these Ileld records, It appears that the loverII mt1ng temperature for breeding in nature 11 es between $45^{\circ}$ and $50^{\circ} \mathrm{y}$.

The average of thirty-four and mum alr temperatures for the breedIng choruses shovn in Table 14 was $65.2 \pm 1.66^{\circ}$ J. The mean naxdman alr temperature was $79.2 \pm 1.66^{\circ} \mathrm{r}$. The nean afr tenperature for the thirty-four chorages was $70.8 \pm 2.480 \mathrm{~F}$. The relat1vely few 
temperature records for the vater of breeding ponds gave a mean of $65.5 \pm 5.01^{\circ} \mathrm{F}$. The extreme nean afr temperatures ranged from a Low of $47^{\circ}$ to a hlgh of $83^{\circ} \mathrm{F}$. Wator temperatures ranged fron $49^{\circ}$ to $78^{\circ} \mathrm{F}$.

TIme of Breeding

It Is generally accepted that the eastern spadefoot is exclusively nocturnal in habit. It alght then be expected that this specles would breed only at nlght. However, both G1Inor: (1924) and. A. H. and M. S. Trowbridge (1937) reported diurnal breeding by 3. bomblfrons. In diseuselng the sactor initlating breeding in Scaphlopus, Brage (1945) mentioned that hoavy rain storme mas overcome the tendency tovard nocturnal habl ts. Fe added, however, that he had found no case of $\underline{\mathrm{s}}$. holbroold breeding in dayllght. A surver of the records in Table 14 shows, however, that of the P1fty-six eases in which the tige of breeding was recorded, twenty-six choruses, or forty-81x pereent, took place at least in part in the daytime. In Iffteen of twenty-gix cases, the toads elther started calling and breeding in the day and continued into the night, or began at night and contimued into the dav, but in eleven instances, breeding took plece exclueively in the day. In general, daytine breeding was probebly accompanled by overcast, cloudy skdes and ralnfeld. However. Wright (1932) stated that one breeding oceurred in rall daylight. 
Irom the totel of flfty-aix ceses, fifty-four percent of the choruses bred exclusively at night.

Type of Breeding Ponda

A. has been mentioned, Bragg (1945) stated that spadefoots breed only (or almost exclusively) in temporary water. Both sanner (1939) and Bragg (1945) postulate the origin of the genus scaphlopens under xerle condstions in southwestern Forth Americs. Precumably this group I1ved here long enough to develop, through a selective process, the zeric breeding pettern asgoclated wh the flash lloods of the southwest. Although the eastern spadefoot now occuples egsentlally a mesle environment (woodlands, Rood plaine, etc), it hes retelned the desert type of breeding and still follows the general pattern of breoding after unuenally hoavg reinfall.

In this connection, 1 is 18 of Interest to note that in Table 14 there are elghty-three reforences to breeding ponds, but only one of these vas a permanent pond. Overton (191/4) reported the occurrence of an April chorus in a small permanent pond, but heary ralns were recorded for the date of this breeding, and the tosds moved to this pond only after stimalation by rain. The vast preponderance of records would seen to prove rather conelustrely that this toad breeds in water that stands por a linited period. 
Multiple Breeding in a single rear

From the assemblage of data in Table 14, it was found that, 11 the necestary environuental conditlons were fulfilled, a single population would breed wore than one time in a glven gear. Mine different observers reconded this phenomenon. It is posalble that a portion of a population breeds on a dven date, and another portion breeds at a later time. It is al so concelvable that several complenents of eget and sperm sre produced in a ctven gear. Ball (1936) was of the opinton that not all of the females in a dren locality necessarily oviposited at the 11ret favorable enviromental opportunity. Driver (1936) stated, "Possibly some observers have been ul aled Into thinidre that only one sparming occurred, when actually the spadofoots may make several emergences durlng one season,"

There is the possibility that the majority of population might breed on the flrst favorable occalon, w th no subsequent breedings occurring oven though optinum emvironmentel conditions preva11. Branat (1936) described a heavy breeding on March 20, 1933. following four dass of intense warm ralns. He vrote, "Whether a second congress can be Initiated by a recurrence of such condtiton: remains tudeterninad; hovever, a sidlar combination of condstions of heery ralnfall and hlgh teaperature falled to bring about a congrese in May of the same gear." 
The following are the annotated records of lonom populations which bred more than one tiwe in a Glien year. Allen (1868) reported the breeding of one population on four different occaslons auring a single year at Cambribge, Massechusetts. In 1934 Driver (1936) recorded a double breeding in the month of April (17 and 2h) at Wor thampton, Massachusetts. At Cambridge, Massachusetts, Putnem (1865) IIsted two chorusea breeding in the same pond on Apr11 19 and April 29. 1863. Ball (1936) recorded the breeding of a populat1on of spadefoots at Ansonile, Connectieut on April 15-18 and agaln on June 11, 1933. In 1934, the same population bred on three different occeslons (Apr11 16-17, May 2-3, and June 29). Overton (1914) Gave three dates (Apr11 27-28, May 5-6, and July 7) Por the same population at Yatchoque. I.I., Mew Tork in 1886. Abbott (1884) recorded breeding on April 10, April 27-28, and June 25-26 in 1884 1n Trenton, Yov Jersey. Richnond (personal conmunication) 11sted e serles of five breeding for one populetion near Lenexh, Virginis during 1944. Spadefoote bred on March 12, 15-17, 23-24, 27-28, and on April 23-24. In 1945. the same population bred on May 27. June 19. and July 18. A double breeding occurred in May of 1948, on May 26 and again on May 29. The records by Dr. and Mrs. C. J. Goln, In Gelneevil1e, Floride show that breeding chorues were formed on April 5 end April 22 in 2949. In the unuevelly wet gear of 1953 they noted I1ve separate breedinga, occurring on March 11. April 7. 
June 14, June 25, and August 22. Pearson (1954) mentioned that one population neex Gainesville bred on Apr11 7 and Auguat 23 of 1943.

\section{Ixtended Pertods of Time whout Breeding}

Thst exvironmental conditlons are necegeary to breeding is evidenced by the fact that populatione in a fiven locallty are imom to have cone extended periods wthout breeding. Commenting upon the Infrequency of thelx breealing. Bell (2936) wrote, "Renericable also is the apparent irregularity of 1 ts emergence in number for breeding. In the llorth during the past 125 years, only about alxteen instances heve been recorded. all sescisted wth heevy raing." Jron this statement, 1 it af be inferred that the spadefoot does not breed every year. Fovever, Ball belleved that the edult females bred every year provided that environmental conditlons were autable.

The recoris now availeble prove that some populetlons do sidp one or more yeers in breeding. It is almost certaln that this is due to the laok of hearg ralneall, optluna temperetures, or both. The records whtch demonstrete thl a phenomenon are Glven belov. Ball (1936) reported that spadefoots appered in Danvers, Massochuset ts In the vummers of 1812, 1825, and 1834, and vere not noticed between those years. Abbott (1884) obeerved a population breeding in Trenton, Now Jersey in 1874 and again in 1884. S1 amon (ungublished data) wrote that he had personelly cheoked on a knom population in 
Neryland following every rain, and that it had not bred for three gears. Richnond (1947) described a chorus on August 15. 1940, at a certain locallty in Iev Kent County, Virginia. He gentioned that this population had not lasd in the prevlous year. In a letter to the witer, Richnond atated that this gan population lalled to breed durlng the years of 1942, 1952, and 1954. Durling the erreptionelly dxy year of 1954, the witer observed no breeding. Choruses in the area around Galnesville, Florida. The lat breeding record by Dr. and Mrs. Goin of Gaineeville, was on Auguet 23, 1953. The population near their home has not bred alnce that $t 1 \mathrm{~ms}$, a spen of twenty-three months.

\section{Experinental Procedures and Results Fiaving Icologleal Implications}

The wefortty of frogs and toads seen to follow a rhythmic, seasonal breeding pattern. In many specles, the seasonal rise in alr and vater temperature seems to initiate breeding. The gonids of these forns, which undergo a seasonal hypertrophy, are full and wature in the spring lollowing the vinter hibarnation. Wright (1946) suggests that FSH (Foll1cle-st1mulating Hormone), secreted by the pltuitary during hibernation, stlmulates foll1eular growth, overian naturation, and a progressive increase in responsiveness Irom lall to spring. Undoubtedly, a full complenent of sperie is also brought to maturation under the inducement of the gonadotropins. It is 
possible that the eyelic, seasonal naturation of the gonads as well as the breeding remponse has becone a genetioally $11 x 0 d$ physelologleal function and behevior pattern, or Instinct (1.e., "a complicated reaction that an antmal gives when 1 t reacts as a wole, and as a representative of a epeeles rather then as an Individual, which is not Improved by experlence, and has an end or purpose of which the anlmal cannot be aware," - Wheoler, 1926).

When the breeding pattern of the spadefoot toad is considered, an entirely different pleture is seen. The rerle type of breeding (Bracs, 1945) Is not 11 at tod to seasonal, cyelle pettern. Iather. 1t tends to be non-geasonel and mey be Indtiated at ang tine of the year when proper ellmetic conditlone prevall. Thls would euggeat that the stimalue is not bohevioral, but is wolly contingent upon elinatic condltions. Jron the preceding review of breeding record (Table 14). only two elimatic conditions which influence ovulation are evident: namely. heary rainfall (sufflelent to form temporary ponds) and tempereture above $45^{\circ}-50^{\circ}$ z. The guestlon arl ses as to how these two environinental factors stinelate the physiology and behavlor of the toad ao as to ind tiete breoding and whether there are other enviromental factore which may also play a role in this process. By means of the In Vitre ovulation technique, It was hoped that the -xact method of stimiation ald ght be determined. 
It is rather generally accepted that the onset of the breeding response in anurans is hormonally 1nduced. Very recently, Bouseay (1954) admitted that the wechand an by wich the nervous system acts upon the pars distalle is stin unknown. It $1 \mathrm{~s}$ belleved that thls mechanism involves neural st1 mulatlon. It is quite probable that the environsental conditions of optinum terlperature and heavy ralnfall in some way act upon the toed's gervous sjstes, which in turn at1zulates the endoerine system. Yoblo (1931) stated that ovilation In amphibia is due to the action of hormones from the anterior lobe of the hypophyals, which 1 is under the control of the nervous system. E. further suggevted that this neural-hornonal response aecounts for the close correlation between breeding and favorable ellmatic conditiona.

The extreme sensitiveness of the anphiblan ovary to hormones from the pars 1 istel1s has wade it poselble to deternd ine the exact gonadotropins which stimulate and seasiti ge the ovary. Wight and H1saw (1946) vere able to demonstrate that the rSH principle (Iresh sheep pitultary) malntains the fros ovary in a highly senoltised state and that only through the combined action of $\mathrm{FSH}$ end III (Lutelnizing Hornone) could ovalation be induced in hypophysectomiged frogs. That the anphibian ovary is extremoly susceptible to pitultary secret1ons has been ably denongtrated. Rugh (1939) found that the frog's ovary. Iollowing hypophysectory, would respond wth a greater 
amount of ovrlation in Ffyo; Wright (1946) found this also true of ovulation in yitre. Wright was able to show that this inerease In ovviation was due to a sensitisation of the ovary by gonedotroplne releaed 1nto the blood at the time of hypophysectoay. In 1945. Wright reported that the injection of a subalnimal dose of pltultery oubstance into an intact frog brought about a sensit1 zation of the overlan tisures and that the response to pltultary Sectors in pitro was greater in sensit1zed than in untreated ovarlos.

It meemed poseible, therefore, that if fomale spadefoots were subjected to the proper stimul1, the overies might becomo sensitised through hypersecretions of gonedotropins. Thls senaltigation could be demonstrated by use of the in pitre orrilation technigue. It might then be assumed that stimull which sensitized the ovarles under experimental conditions might also be the stimall which are 1mportant In indtiating breeding under natural conditions. To test this hypothsis. Pemele toads were exposed to such conditions as light, ebrupt chenges of temperature, lowered atmospherie presenure, and vater.

\section{Effects of Light and Darioness on Temele Toeds}

It is well known that the seeretion of gonadotropins by the Dars distalls stimalates the breeding response, ovuletion, and opermation in the majority of vertebrates. Since ilght initiates 
this process in some birds and manmals, it seened logical to test the effects of 11 ght on Scenhiorus. Hovever, stnce this animal is knovn to be both nocturnel and fossorlal, the poselblilty of positive results seemed sorewhat remote.

Fifteen fomeles vere placed in absolute darimese imediately after capture. These vere measured (head wath and velght) in a photographle darleroos wnder a stratton Safelight (Serles OA), and elght individuals of oimllax stze were selected for the experinent. Four control tonds were kept in the darioroon in complete derteness. The four experlmental antwals vere removed to an adjointing roon of ths sane temperature $\left(82^{\circ} \mathrm{r.}\right)$ and exposed to continuous $11 \mathrm{ght}$ for Iorty-elght hours. Two 100 vatt bulbe vere used as the sousce of 11ght, and one bulb we placed 12 Inches from each side of the glast container holding the tosds.

At the end of a forty-elght hour perlod, the control toads were sacrifleed in darkese, whl the experinental toads were secrlflced in the 11ght, and four pleces of ovary were selected from each toad. Iach plece was placed In a vial containing the equivalent of one-half pltustary in $5 \mathrm{ml}$. of Foltereter's solution. The Individwal and meen ovilation percentages are shown in Table 15. The sixtsen tests performed on femel os exposed to 11 ght geve a mean of $32.2 \pm 5.5$. on those exposed to dark, $26.6 \pm 4.0$. When these date were compared 


\section{PABTA 15}

II VITRO OVULATIOI DESULTS OBFATRED MON

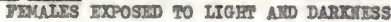

\begin{tabular}{|c|c|c|c|c|c|c|}
\hline \multirow{2}{*}{$\begin{array}{l}\text { Type of } \\
\text { Exposure }\end{array}$} & \multirow{2}{*}{$\begin{array}{l}\text { Jumber } \\
\text { of Toad }\end{array}$} & \multirow{2}{*}{$\begin{array}{l}\text { Percent } \\
\text { p1t. in }\end{array}$} & \multicolumn{3}{|c|}{$\begin{array}{l}\text { ovalation using } 1 / 2 \\
5 \mathrm{ml} \text {. of Holtfreter's } \\
\text { rivid }\end{array}$} & \multirow{2}{*}{$\frac{\text { Mean }}{23.35}$} \\
\hline & & & $33 \cdot 3$ & 14.3 & 20.8 & \\
\hline \multirow{4}{*}{ Dark } & 2. & 18.7 & 35.0 & 31.6 & 68.0 & 38.33 \\
\hline & 3. & 38.7 & 34.4 & 9.1 & 37.5 & 30.02 \\
\hline & 4. & 44.0 & 13.0 & 0.0 & 3.0 & 15.08 \\
\hline & \multicolumn{6}{|c|}{ Mean $26.56 \pm 3.97$} \\
\hline \multirow{4}{*}{ Ilght } & 1. & 35.0 & 15.0 & 16.3 & 27.3 & 23.40 \\
\hline & 2. & 22.2 & 69.7 & 41.0 & 20.2 & 38.27 \\
\hline & 3. & 46.2 & 31.0 & 50.0 & 22.7 & 37.47 \\
\hline & 4. & 14.3 & 88.9 & 12.8 & 0.0 & 29.00 \\
\hline
\end{tabular}


tatisticelly, no significent difference was found to exd st $l_{t}=0.81$, P. $\left.>0.05\right)$. From these results 1 t vas coneluded that II ght does not act as a stimulus to the toed pituftary and consequently seneltigation of the ovarles does not occur.

Iffect of Abrupt Changes of remperature on Femele Tosds

That temperature has effects upon the breeding response of amphibia is voll 11lustrated by the Spand sh nevt (Pleurodelee valt1). Yoble (1932) reported that fomales of this apectes may be Induced to ovulate merely by placing them in a low temperature over af ght and then removing then to a tank sustable for breeding. According to Foble, the sudden $r i s e$ in temperature inftiates the ovulation eyele and both courtehlp and breeding will frequently follow.

In many instances of spedefoot breeding, the ground temperatures have been quite low and are subsequently raised with the coming of ware rains, Ball (1936) wrote that many of the April breedings in Connecticut come wh the first apring rains wich thaw and werm the ground. Peerson (1954) reported sour breeding choruses in Ilorlds whlch were assoclated with cold Pronte eventually broken by heavy ralnfall. S1mone (perconal communteation) wrote that a Maryland breeding was preceeded by a veek of freezing weather. This cold period wee broken by warm relns whlch evoked the breeding chorus. 
In each case, the exdating temperature was low and was followed by a rather sudden rise in temperature. In order to test the effects of tellperature upon the toads, these conditsons vere duplicated, as nearly as poseible, in the laboratory.

Ilght femele toads of approxtmately the same size were used. Four experimentel enimals vere placed in a gallon jar contalning one-fourth inch of vater and put into a refrigerator set at $54^{\circ} \mathrm{T}$. Your control toads were placed in a jar contalning water and kept et room temperature $\left(73^{\circ}\right.$ r.). Neter a twelve-hour perlod, the experimentel toads were brought Into room temperature and kept there for six hours. Then, both the control and experimentel aninels were secriflced; thelx ovarles vere revoved, and four fragments of ovary were obtalned from each toad. Ench fragnent was placed in a vial contalning the equivalent of one-half pituitary in $5 \mathrm{ml}$. of solution.

The ovulation results for these tests are show in Fable 16. The meen for the experimentel fomales exposed to lower temperature was $26.3 \div 3.4$ percent and for the oontrol toads held at rool temperature, $31.0 \pm 4.0$ percent. It was found that no statisticel difference exlsted between these means $\left(t,=0.91, p_{0}>0.05\right)$. It was concluded, therefore, that lowered temperature hed not sensitizod the ovar1es. 


\section{TABIE 16}

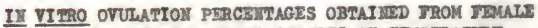
TOADS EXPOSED TO ABRUPI CEAIGIS OF TRMPERATURE

\begin{tabular}{|c|c|c|}
\hline $\begin{array}{l}\text { Exposure } \\
\text { Temperature }\end{array}$ & $\begin{array}{l}\text { Irwomber } \\
\text { of Toad }\end{array}$ & $\begin{array}{l}\text { Percent ovalation using } 1 / 2 \\
\text { P1t. in } 5 \text { ml. of Holteroter's } \\
\text { Fluid }\end{array}$ \\
\hline
\end{tabular}

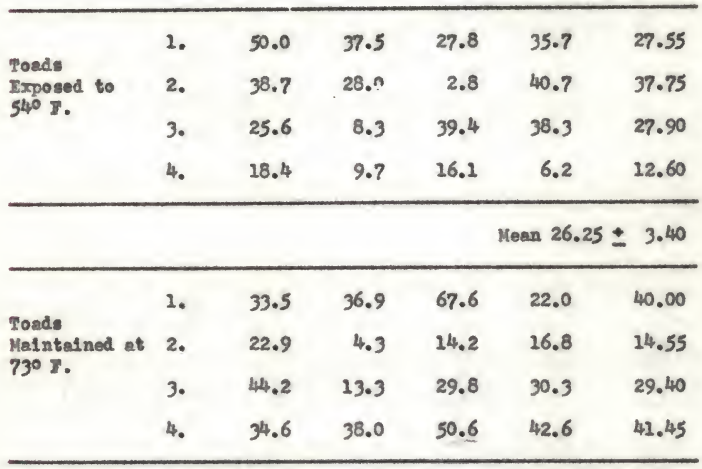


Ixposure of Feiter Toads to Lovered Atmonpherte pressure

It 1 s rather well estebl1 shed that spadefoot toads breed during heavy rain storms, extended periods of xainfall accompanted by stationery or permenent cold fronts, and hurricenes. Low atmogpheric preserure often eccompentes these clinat1c ds sturbances. A number of natural1sts heve expressed thelr bellef to the writer that spadefoot breeding ad fht be stimulated by heavy rainiell and low atnospherlo preasure. In a study of the response of sallentia to chorionle gondotropin. Inepton (1951) subjected nale spoderoots to lovered pressure of $726 \mathrm{~mm}$. of mercury $(94.2$ percent of an atmosphere). He hypothesized that sperniation algt be stlawieted by lowared preasure combined wth an injection of hormone. FIs results were contradictory, however, since toads exposed to low pressure reacted both pout1vely and negatively (by spernation) following injections of chorionic gonedotropin.

Therefore, a atudy of the effects of lowered preseure upon the pltuttary-gonad belance of the fenale seemed varranted. A largo pyrex denl John ( $9650 \mathrm{ml}$.) was 11 tted $\mathrm{wth}$ a sealed rubber stopper baving two glass-tube outlets. One of the gless tubes wer bent Into a "U"-sheped fora which held a colum of mercury. Thls was backed by allineter graph peper so that fluctuations between levels of the two colums could be read accurately to the nearest 
millnoter. The gecond gless tub was connected to a chort length of rubber tublng whlch served as an exhaust outlet. This was attachod to a Iaucet aspirator and alr was eracuated from the bottle to obtaln the deslred redused pressure. Double clanps vere placed on the rubber hoge near the glass outlet. Mo leakage val ovident after a prellulnary trial of one weak.

On September 17. 1928, a hurricane passed through Galnesville, Florida producing an atmospheric pressure of 28.94 inches (735 am.) of mercury. This pressure vas chosen as the low velue for this experimental work. To obtaln thi pressure, a reading was taken from a locel barometer, and the difference In millmeters of mercury between the eurrent atmospherle pressure and the desired pressure vas deteruined. Alr was then exhausted from the bottle unt1 the desired pressure vas obtained. Control toads were kept at the atmospherle pressure of the room, Minor preserure Pluctuations, due to changlng westher conditions, over the forty-olght hous period of the experiment, offected both experimental and control animela allike. It was recogni zed that a aynergletlc effect of lowered pressure and water alght stimalate the toads to Increaged ovalation. Therefore, two experlnents vere conducted. In the flrat, the experimental and control aninal. vere put into Jars oontalning no water. whlle, In the second, both experimental and control toads were kept In ons-fourth inch of vater. 
Thie ovulation reeulte from both experiments are recorded in Fable 17. Ho statistical differences were found between the maans of the experimentel and control females kept in a dry state (t. = 0.59$. P. $>0.05)$. Iskendse, Lemeles exposed to normal and Iow tenperatures while seated In water gave no signifleant differences In ovilation recults $\left(t .=1.30, s_{0}>0.05\right)$. It wes concluded, therefore, that lowered atmospheric pressure had no effect upon ovarian seneitisation.

It was of interest to note that those antmals placed in vater had a higher mean ovilation pereentage then the toads kept in the dry condition. When the ovilation means for the wet and ary experimental toads were compared, a slgniflcant difference was found to exd st (t. $\left.=2.99, P_{0}<0.01\right)$. However, the comparison between control animals exposed to wet and dry conditlons falled to attaln sl gail1cance $\left(t .=1.28, P_{.}>0.05\right)$. In the following seotlon, conslderation 18 glven the role that water plays in the stimulus of the toad's pltultary Eland.

Ifrects of Water Upon Female Toads

Rather early In the study it wa lound that lenele toad brought directly from the Ileld occalonally gave low or negative ovrlation resuits. It was noted thet this pecullarl ty seemed to be correlated 


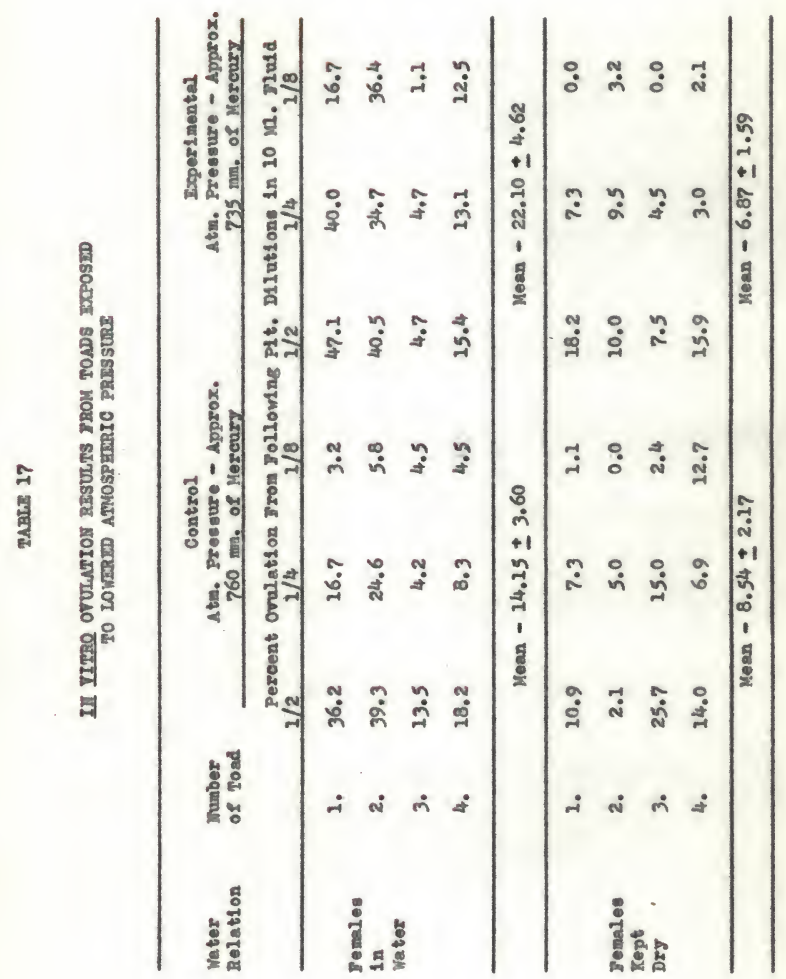


win dry $0011 \mathrm{~s}$ at the collection st te. A few toad kept on nolst peper tovele in etorage jars gave simpler results. However, those femeles held in ellor storage Jars contalning one-lourth Inch of water reacted normally to the in vitro tests.

prellainary tests showed that those femeles kept in water, previous to the renoval of their ovar1es, ylelded higher percentages of orvlation, whlle toads kept under dry conditions gave very low orulation regults. 0ccaslonally, Mg Semales retelning large amounts of fluid in their bladders and lymph eace gave normal ovulation results in spite of aubjection to dry conditions. In generel, hovever, there seemed to be a drect correlation between percentage of orulation in V1tro and exposure to vater. Three different types of experImenta ware performed to investigate this reletionship of vater to ovalation.

Exposure of remeled to vet and Dry Conditions. In the Iret experlneat, experinental toads were kopt in finger bowls containing $100 \mathrm{ml}$. of tap vater, and control toads of ofmilar size vere placed. In bouls witch were dry. Orine whe removed from the ary contalners throughout the period of exposure. The aninals vere held under these conditions for a period of forty-eleht hours and then secrlficed for their ovarles. These were exposed to stock pitultary dilutions and the ovulation percentages obtalned. A total of flfteen comparisons 
of this type were conducted ueling thirty femeles and thirty melea (pltultary donors). The individual and mean ovilation percentages aro show in Teble 28, whlle graphle comperlscn of these results Is shown in rigure 21.

A statisticel analysis was mede between the ovilation percentages, at the one-half pituitary level, for toade exposed to wet and dry conditions (Teble 19). A slgniflcent differencs was found to exdet in this comparison $\left(t_{0}=2.95, P_{0}<0.05\right)$. A second mare generall zed analyais was made in which ovuletion percentages were taken from all pltultary dilutions (one-half to one-sixteenth) under the two conditions and compared (Table 19). Agaln, a genificent difference was obtalned, wth $t_{0}=4.4$, and $P_{0}<0.001$. It is zether generally known that anurane demonatrate active water-uptake until a physiological optimum is renched, and, from these results, it appears that the presence of water is necessary to normal ovulation.

Exposure of Jemales to a Soll-1Mo1 sture Gradlent. After the vater-ovilati on relationship had been demonstrated, it seemed worthwh11. to Inventigate the amount of and sture needed to induce a physlologicelly optiman state for normel ovulation. The spedefoot IIves in a burxow and 1s undoubtedly affected by flnetrations in so11 molsture. Therefore, an experiment was declgned uaing a eradient of soll nolstures. It was hoped that a eriticel noleture 
TAats 18

III VITRO OVULATIOI FERCEMTAGES OBRAINDD USIMG OTARIMS

TAKEI TROM TMMALES SUBSECTED TO WET ATD DRY COIDITTOAS YOR 48 HOURS

\begin{tabular}{|c|c|c|c|c|c|c|c|c|}
\hline \multirow[t]{2}{*}{ Date } & \multicolumn{4}{|c|}{ Wet Condition } & \multicolumn{4}{|c|}{ Dry Condition } \\
\hline & 1 & $1 / 2$ & $\begin{array}{l}\text { Anotunt } \\
1 / 4\end{array}$ & $\begin{array}{l}\text { of } \mathrm{Pd} \\
1 / 8\end{array}$ & $\operatorname{lery}_{1} \ln$ & $10 \underset{1 / 2}{M}$ & $\frac{7 \text { luda }}{1 / 4}$ & $1 / 8$ \\
\hline $6-26-54$ & $\begin{array}{l}46.2 \\
38.1\end{array}$ & $\begin{array}{l}32.5 \\
38.8\end{array}$ & $\begin{array}{r}4.0 \\
64.1\end{array}$ & $\begin{array}{r}15.6 \\
0.0\end{array}$ & $\begin{array}{l}2.0 \\
0.0\end{array}$ & $\begin{array}{l}2.9 \\
0.0\end{array}$ & $\begin{array}{r}21.4 \\
2.6\end{array}$ & $\begin{array}{l}4.8 \\
0.0\end{array}$ \\
\hline $6-26-54$ & $\begin{array}{r}32.9 \\
2.3\end{array}$ & $\begin{array}{l}45.1 \\
13.2\end{array}$ & $\begin{array}{r}18.0 \\
3.9\end{array}$ & $\begin{array}{l}8.7 \\
0.0\end{array}$ & $\begin{array}{l}6.7 \\
5.9\end{array}$ & $\begin{array}{r}0.0 \\
12.5\end{array}$ & $\begin{array}{l}0.0 \\
2.9\end{array}$ & $\begin{array}{l}0.0 \\
0.0\end{array}$ \\
\hline $6-30-54$ & $\begin{array}{r}7.0 \\
49.0\end{array}$ & $\begin{array}{l}20.8 \\
12.8\end{array}$ & $\begin{array}{r}19.5 \\
3.6\end{array}$ & $\begin{array}{r}34.0 \\
0.0\end{array}$ & $\begin{array}{l}27.5 \\
17.6\end{array}$ & $\begin{array}{l}2.1 \\
1.7\end{array}$ & $\begin{array}{r}10.0 \\
1.8\end{array}$ & $\begin{array}{l}0.0 \\
0.0\end{array}$ \\
\hline $7-1-54$ & $\begin{array}{l}31.9 \\
17.0\end{array}$ & $\begin{array}{l}13.0 \\
30.4\end{array}$ & $\begin{array}{r}30.8 \\
5.9\end{array}$ & $\begin{array}{r}11.8 \\
0.0\end{array}$ & $\begin{array}{r}5.7 \\
17.9\end{array}$ & $\begin{array}{r}19.2 \\
8.8\end{array}$ & $\begin{array}{l}3.0 \\
0.0\end{array}$ & $\begin{array}{l}0.0 \\
0.0\end{array}$ \\
\hline $7-6-54$ & $\begin{array}{l}62.5 \\
10.0\end{array}$ & $\begin{array}{l}36.4 \\
14.0\end{array}$ & $\begin{array}{r}42.9 \\
9.4\end{array}$ & $\begin{array}{l}0.0 \\
0.0\end{array}$ & $\begin{array}{l}0.0 \\
0.0\end{array}$ & $\begin{array}{l}0.0 \\
0.0\end{array}$ & $\begin{array}{l}0.0 \\
0.0\end{array}$ & $\begin{array}{l}0.0 \\
0.0\end{array}$ \\
\hline $7-12-54$ & $\begin{array}{l}12.2 \\
11.1 \\
25.9\end{array}$ & $\begin{array}{r}0.0 \\
42.2 \\
15.7\end{array}$ & $\begin{array}{l}0.0 \\
9.4 \\
3.1\end{array}$ & $\begin{array}{l}2.9 \\
5.1 \\
0.0\end{array}$ & $\begin{array}{r}0.0 \\
12.8 \\
25.0\end{array}$ & $\begin{array}{r}0.0 \\
40.0 \\
28.6\end{array}$ & $\begin{array}{r}0.0 \\
9.4 \\
30.7\end{array}$ & $\begin{array}{r}0.0 \\
2.6 \\
19.0\end{array}$ \\
\hline $12-1-54$ & $\begin{array}{r}14.0 \\
7.5\end{array}$ & - & - & - & $\begin{array}{l}0.0 \\
0.0\end{array}$ & - & - & - \\
\hline Mean & 24.8 & 24.2 & 16.5 & 6.0 & 8.3 & 8.9 & 6.3 & 2.0 \\
\hline
\end{tabular}




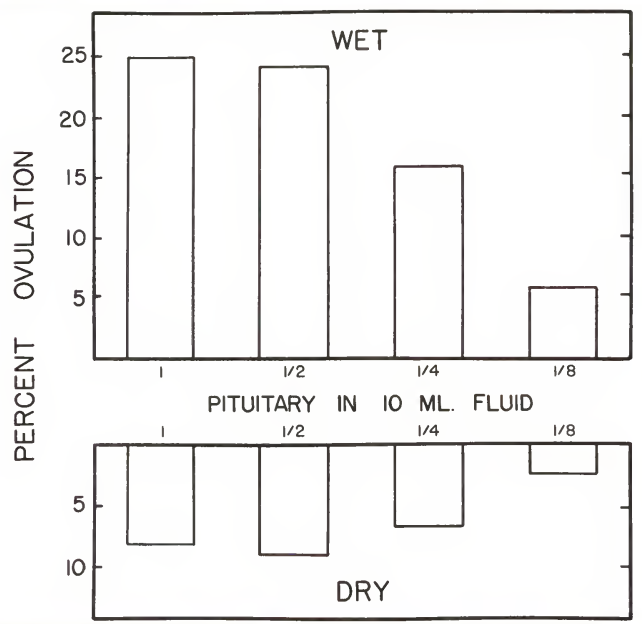

IE. 11. In Vitre ovalation resuits obtalned fron semale toad. exposed to wet and dry cond1 tions. 


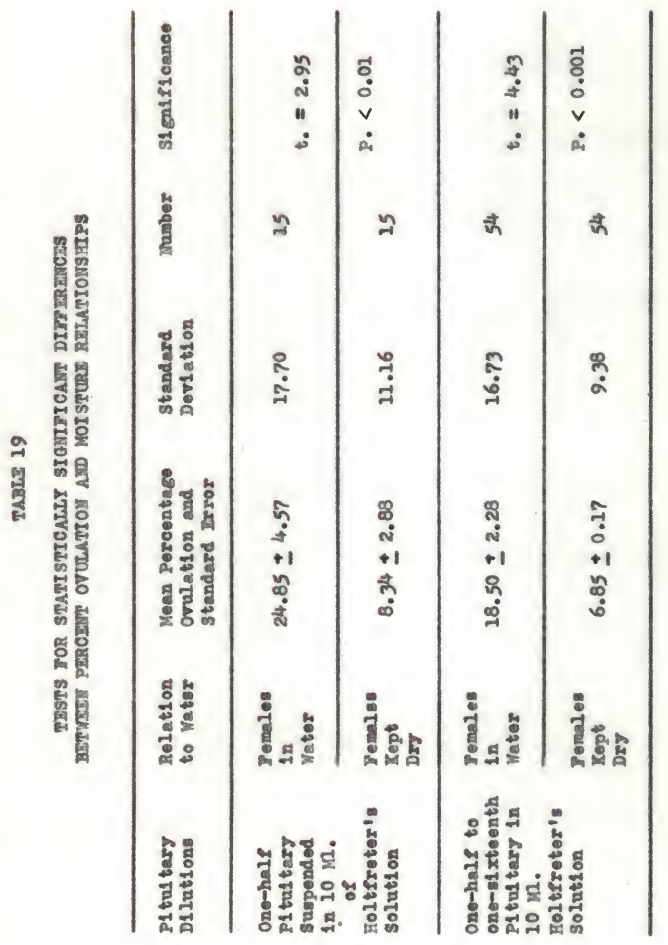


percentage might be found, above whlch ovriation would proceed norvelly, but below whlch water-upteke would be insurfleient for orulation to occus normally.

A large quantity of aoil taken from a burrow alte was oven drled for forty-elght hours. Soll ellquoto of 300 grams were placed In elx IInger bowls. By dry welght of sol1, the following percentages of tap water were added to the six so11 samples (50\%, 45\%. $33 \%, 25 \%, 20 \%$, and $0 \%$ ). In the bowls contalining porty-1ive and Iffty percent vater, the soll was beyond the point of seturation and a P1In of wates stood above the so11's wurface. Bach Pinger bowl was covered by a second inverted bowl to prevent molsture losa. Two fenele toads were put Into each soli samplo and alloved to burrow. The toads were removed in forty-elght hours, macriflced, and their ovarles used in ovulation tests. Tour pleces of ovary vere taken from each toad and each was suspended in e vial contalning 5 mi. of p1 tuitary suspension. Toads exposed to soll molstures of 50 . 45. 33, 25, 10, and 0 percent gave mean ovulation percentagen of $70.0,49.0,48.2,24.7,2.7$, and 6.3, respectively. Although no sherp break in oviletion occurred at any level of soll nolsture, reduction of soll molsture seemed to have a gradual inhibitory effect. Thi furnishes additional support for the 1dea that ovulatIon seems to be correlated with exposure to mol ature. 


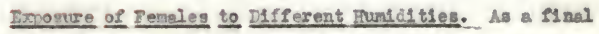
test of the effect of noloture, a nerles of chambers wore enploy ed In which humidities renged srom 0 to 98 percent. These chanbers constatnd of gellon jars containlng an exoeso of certaln sal to in saturated solutlons. It is vell lonown that a saturated aqueeus solutlon (vater) in contact wth an excess of a deflnt te solid phase ( $\mathrm{s}$ eilt). M11 malntoin a constant mindalty when kept in an enclosed space at efven tempereture. Fron the International Critical Tables (1926), certain salt (Table 20) vere selected which would produce deatred humflities et $20^{\circ} \mathrm{C}$. Ixeess amounts of these salt vere placed in $200 \mathrm{ml}$. of iletilled vater in each of I1ve jars of one galion capesty. To achseve a zero hunidity. 150 xam of $\mathrm{CaCl}_{2}$ were placed in a wixth jar. A t1ghtly iltted platform of oneIourth Inch herdiere cloth was expported 3 inches above the solution by a zlassware foundation.

The verles of fars were kept in a refricerator set at $20^{\circ} \mathrm{C}$. and entmals were glven a twenty-four hour pexlod of exposure. Toeds held at lower humlditieg tended to desiccete rapldig. It vas for this reason that the perlod of treetnent was reduced frow the fortyel ght hours exployed in the experiments on temperature, nol ature, atmospherio pressure, etc. to twenty-lour hours. Ipon renoval from the humd d ty chembers, toede were revel ghed and then eacrificed. Four pleces of ovarles vere taken from each toad and surpended in 


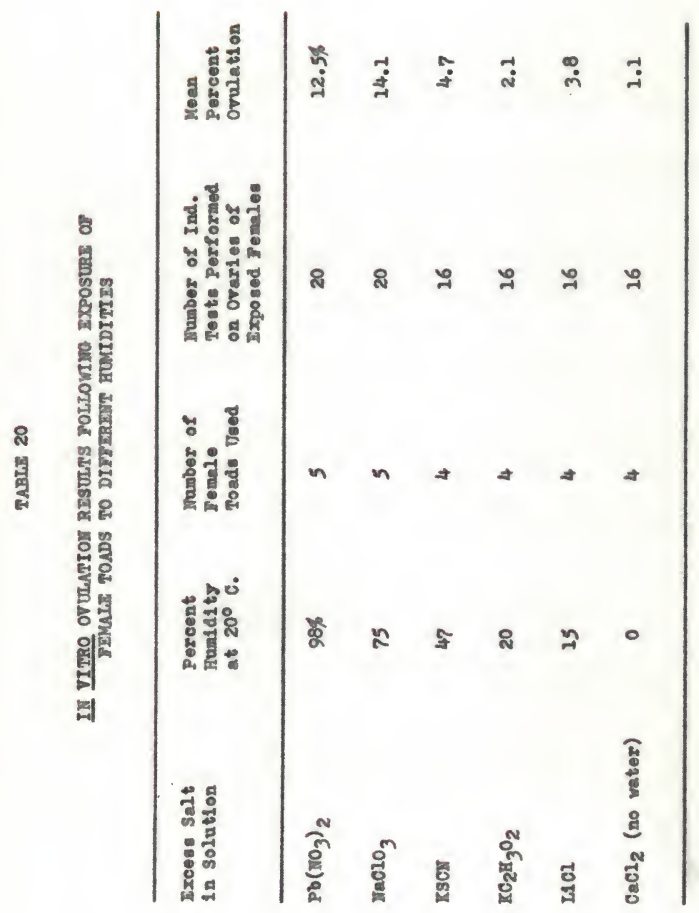


dilutions of pitustery vargline from one-hale to one-gixteenth enterior lobe in $10 \mathrm{ml}$. of Holtsreter's flule.

Meen percenteges of ovelation for the gredient of humiditles were as 20110ws: 98\%) - 12.5; 75\%) - 14.1; 47\%) - 4.7i 20\%) 2.1; 15\%) - 3.8; and $0 \%$ ) - 1.1. On Inspecti on, this seents to Indicate a airect correlation between percentrage of ovilation and humldity (Table 20), and this conclust on was valldated when the data were anelyred statisticaliy. A atrong positive correlation was found to exd at between ovilat1 on and bums dity $(x=0.45 \pm 0.26)$. and It was found to be statisticully alenificent (t. $=2.5$. p. $=$ 0.02). Therefore, each of the three entirely d1fferent types of experimenta dealing with molsture indieates that molature plays a very 1 mportant role in producing ovilation.

\section{Txposure of Itypophysectoml zed Toads To Net and Dry Cond1tions}

Wright (1946) reported that a marked ineresse in ovilation In Ditro followed hypophysectomy, in Rens pipleng, due to the senel tization of the overy by the release of gonsdotroplns. Because 1t had been denonatrated repeatedly in the present work that exporure of foreles to molsture might bring about ovarisn senvitization in the spedefoot, It was decided to test the effects of wet and dry conditions on hypophysectomi zod anlmalm. 
In removing the pere distalis. Iemales vere put under a light anesthesis whth ether. It was possible to open the gape of the mouth surfloiently wo that 16 was not necessery to cur and extend the angle of the Jaw. A mall, three-elded flap was cut in the sldn of the roof of the mouth. This was folded back pesterlorly and the parasphenold bone exposed. A wmall hole was drilled through the bone at a medial point interwected by a 11ne dram throuch the anterlor odgen of the two Laterel projections. A high-speed, Nlexdble-shast hand-drlll wes used along wth a dentel bur (No. 4 atrelght handplece). Dpon penetrating the braln case, any excess blood and body Pluld were renoved by apgl ration, but little slooding occursed throughout the entire operation. The pars Aistalls was lifted out with a pair of 11ne-pointed forceps. Care was taken not to remove the pare nervose and pars 1nternedis, because of the Importance of the former in malntalning water balance. Mo sttempt was made to suture the orsl macosa since it had boen reported that the thread and knots only cause additional Irritation (Wright and Nacintyre, 1950). The animals recovered rapidiy from the effocts of the anesthesia and the operation.

The pers distells was removed from four toad in the menner described. Tho of these toads were placed in a jar contalning onefourth inch of water. The remaining two toads were held in a dry jar. Mfter a lorty-lght hour exposure perlod, the toads were 
sacrlflced and their overles removed. Four pleces of ovary were

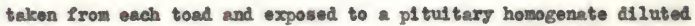
to the equivalent of one-half pitustary in 5 m. of Holtereter's solution.

The ovilation resulte from the two sixteen-vial serles were remarkebly simflar. The mean pereentage of ovulat1 on for hypophysectonised tord exposed to wet and dxy condlt1ons was $21.3 \pm 7.1$ and $25.6 \pm 6.5$, respective1y. The meen were compared statist1eally. but were lound to lack a slgnilleant difference ( $\left.t=0.40, p_{*}>0.05\right)$. Mean ovelation values for the control toads vere $28.8 \pm 7.7$ pereent for the two toads exposed to vater, and $7.3 \pm 1.6$ pereent for the paix of fernales subjected to a dry state. A statistically ignificant difference vas found when these two neans were compered (t. $\left.=2.56, p_{0}<0.05\right)$. The Individual and mean ovalation results for both the hypophysectoml zed and nornal toads are shom in Table 21.

These results 1ndicate that exposure of hypophyeectoul zed. Penales to raxying conditions of molsture produces no slgnilicant differences in the percentage of orviation. Since the percentege of orulation in all of the hypophysectomb red fonales was approxdmeteIf the same all that found in normel antaels exposed to water, the ovarles of hypophysectomf zed ant mals must have been pre-sengl t1 zed, thereby ellminating the necessity for water. Seemingly, the orarles 
TABLE 21

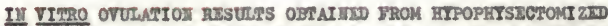

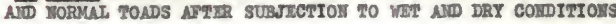

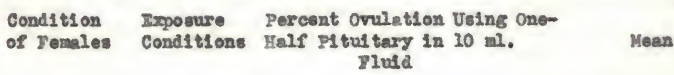

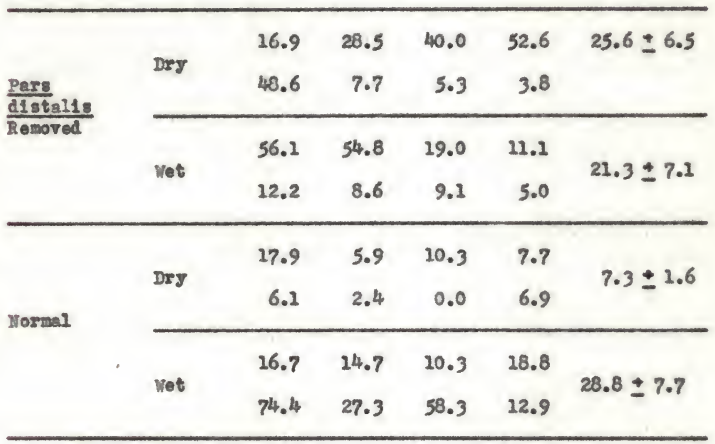


of both groups of hypophysectori sed animels had been maximally sensitized, since water had no added stimalstory effect. Fhus, in Scaphloors holbroold, as in Rens Dipiens, hypophysectoany seens to bring about a sensitization of the ovary. Thla may vell be, as Wright (1946) indicated, the regult of the release of gonadotropins at the t1m of hypophysectory, al though no attempt wes made to determine this in the spadefoot. Thls leaves unsolved the problen of how exposure of the fenale gpadefoot to water sensitises the ovary.

\section{Monthly Condition of spadefoot Gonads} in Relation to Breeding senvitivity

It is woll known thet certain amphbla resorb their egge and spern $1 f$ favorable environmental conditions do not prevall during their urual breeding season. Rugh, (1951) in alscusstng Rana piplens, reports that if the ferale is forced to retaln her egse begond the normal breeding perlod, the ova will start to eytolyse in the ovary. Howrrer, Ileld data Indicate that the apsedefoot, unilke Rens plolens, Is not a seasonel breeder, but hay breed in any month of the goar when environmental conditlons are rultable. Writing about the eastern spadefoot toad, Ball (1936) sald, "Scaphlopus seems able to retain 1 ts ove and spera until temperature and water conditions are favorable - even unt1l midsunmer." Trowbrldge 
and Trowbrigge (1937), worldng with S. bomblerong state, "It remains to be shom hov long gpedefoot females can retaln ripe oggs and have then fert111 sable when 1a1d." In an attempit to determine how long mature viable enpern and ova might be retained, the condition of the goneds wes ohecked each month for a perlod of one yeer.

Monthly Rat1o of ovary Velght to Body Velfht. It seened loglcal that is the maturation of ovaries (ane to an increase in number of eggs, an increase in stored yolk materials, or cell growth) were seasonal, it might be revealed by comperative ratios of ovarles to body weights. Each wonth, therefore, the ovary velghts of ten or more Iemele toads vere recorded and averaged. These rat1o percentages, along $w$ th the number of Ponales racrifleed are shom in Table 22. The means for December and Aprl1 showed the widest range, but a statisticel comparison between the two falled to thow a alenticant difference $(t .=1.2, P .>0.05)$. Fron these results, It wes concluded that in the absence of ovulation, female spedefoots carry a full complement of neture, viable eggs at all times of the rear.

Comerative Monthly Study of In Iitre ovilation. In 1937. Bugh showed that there vas a marlod seasonel varlation in the ausceptibility of the ovary of $\mathrm{g}$. Diplens to pltultary-1 aduced ovulation and that a greater anount of pltultary ves required to 


\section{TABLE 22}

COMPARATIVI WONTFLY RATTO OF OVART

WHOHF TO BODY WRTOHT

\begin{tabular}{lcc}
\hline Month & $\begin{array}{c}\text { Iruber of } \\
\text { Individuals }\end{array}$ & $\begin{array}{c}\text { Mean Percentage } \\
\text { Ovaryt }\end{array}$ \\
\hline August, 1954 Welght
\end{tabular}


produce a Glven anount of ovvlation in Ootober than in Narch. wright (1945) conducted an in itro ovulation strdy wh this same species and found that there was a progreselve 1nerease in reaponse to pitustary materials from 耳ovember (9.5\%) to April (89.0\%). Since the spedofoot is lonown to breed In practl celly any sonth of the year, 1t seemed 1arportant to test whether such a seasonal peak of ovulation oeeturred in this form.

To deternd ne this, a largo standard1 zed pl tul tary eolution vas needed, to that oqual allquots (hold in a frozen stato) could be used for monthly in fltro tests. To secure auf Ilelent pitultery for wuch a stock solution presented a problen becauge of the Impractlcablilty of collecting a large nuesber of toads at one time. For this reason, a stock solution, consl sting of twelve macerated wale pl tul terles suspended in $120 \mathrm{ml}$. of Holtfreter's solution, was prepered each month. Thls solution vas then divided into trelve vials and Irozen for future use. Wright (1945) found that frozen p1 tul tary solutions retained thelr hormone titer for extended periods of t1m.

Irech month one female toad was sacrificed as an ovary donos. V12lo of Irozen pltaltary from och monthly pl tultary preperation were thewed, and aluted to the equivalent of one-half, one-fourth, and one-elghth of a pltuitary in $10 \mathrm{ml}$. of fludd. Thls experiment was begun in Angret, 1954, and in esch consecutive month an additional 
vial of pitustary was used, so that by the twelfth month thirtysix vials vere omployed to test the representative fomelo of the month.

The monthly ovilation results Sor each Irozen pltultary preperation are shown in Table 23. When the monthly ovelation percentages are averaged and compared, the results are Lound to be falriy consistent, Indieating that no seasonality in gonad aetivity exists. A stetistical compari son was made Lor the ovilation results obtained Irom the three dilutions used. At the one-hals pituitary concentration, the months of Fobruary and June had the greatest difference in ovulation means, but when compared statistically these showed no slenifleant differences $\left(t .=1.9, p_{0}>0.05\right)$. The months of Mareh and June had the wldest divergenee in ovilation results in the one-pourth pituiterg allution range; nevertheless. no statistical differences exd sted $\left(t .=1 . B, p_{.}>0.05\right)$. The greatest range in ovilation percentages for the one-elghth pitultery dilution were found in March and Juaw, but a statistical comparison whowed that the differences were insignlfleant (t. $=0.33$, P. $>0.05$ ).

Since no peake in overy cenaltivity were found for any month or serson of the year, It mey be assuned that the femele is capable of breeding during any wonth. The three statistl cal comparlsons verify this assumption. 


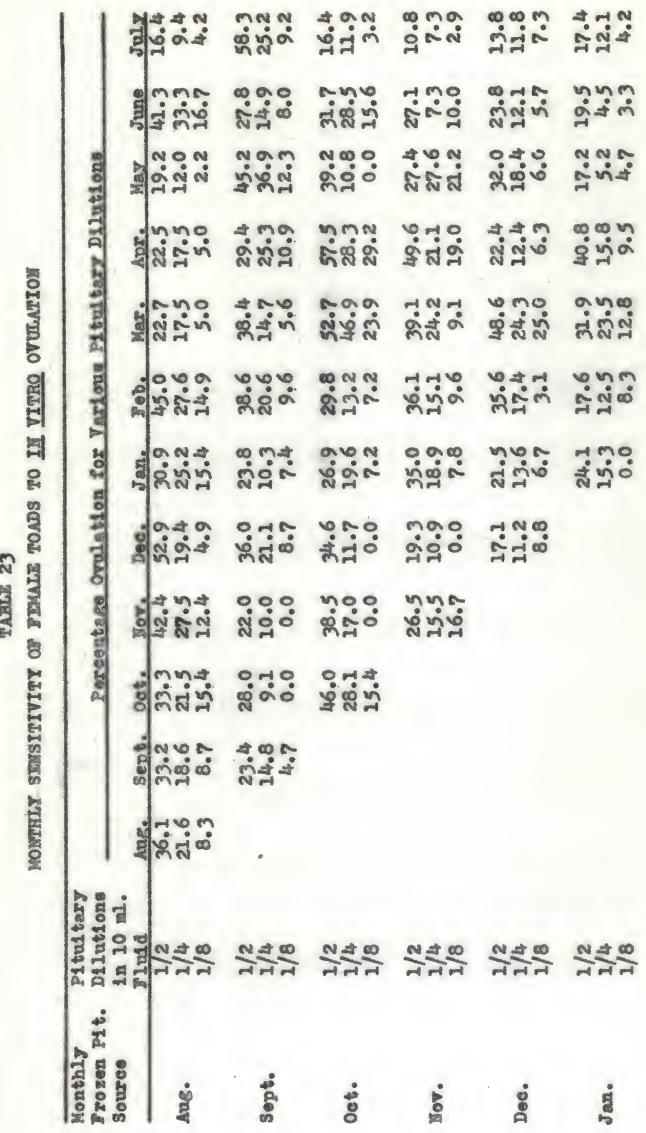




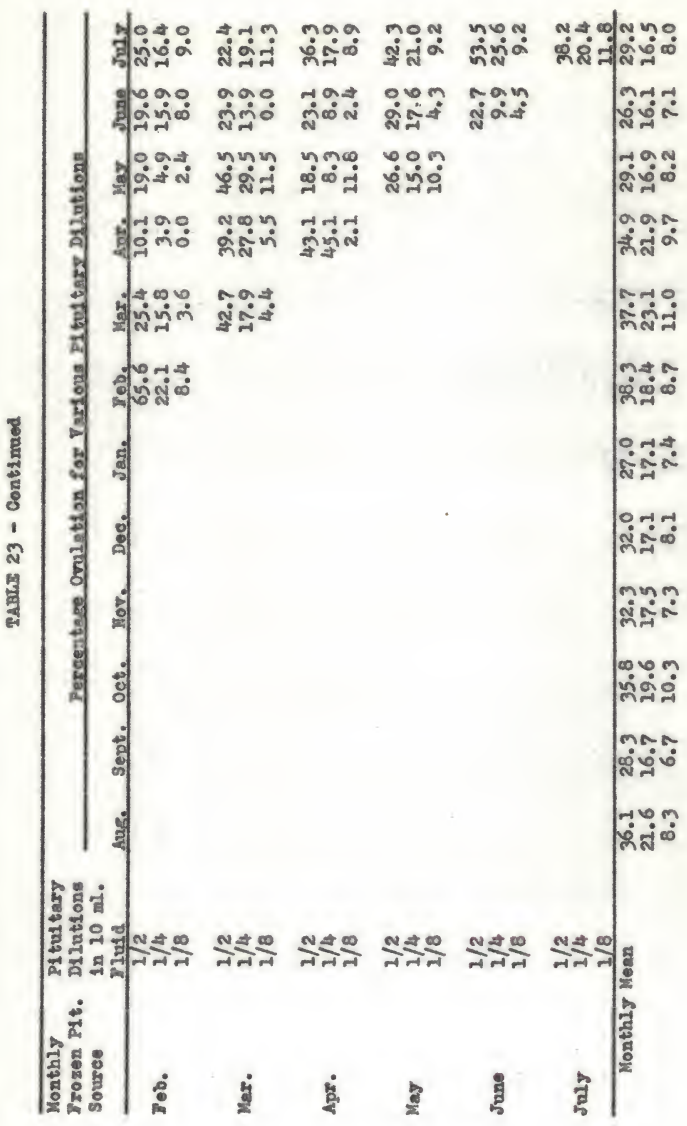


If. It is true thet the fomele spedefoot is not a seabonal breeder. It seened necesuary to determine whother the nale tond wea likenlse cepmble of breeding throughout the year. Therefore, In each month fron July, 1954, through June, 1955, two male toads were injected wh the equivelent of two mele pitultarles mecereted In $1 \mathrm{ml}$. of Amphibian Rlinger's Solution. Sperm befag found in the wrine of each enimel, in every month, indicated thet mature, viable aperen vere present in the testes and that the male toad was almost certeinly capable of fertilizing ove under natural conditions. 


\section{DISCUSSION}

The question may be ralsed as to whether the In I1tre ovralstion technique whlch has been exployed, not only in this atuds, brat also by other workers, is a valid method of studying ovilation and the factors involved in this process. Hellbrunn, Daugherty, and Milbur (1939) pointed out that sgse shed from ovaries of Rans plofens and suspended in pl tul ters solutions showed polar body formation as do eggs ovulating naturelly. In 1940, Ryan and Grant flurther substentlated the normellty of In vitre ovilation by reporting that egge, ovulated In Vitre and pasaed through the oviducts of an ovar1sctond zed ferele, were capable of beling fertillsed and producing avining tadpoles. Wright (1945) showed that the relationship between the percentage of ovilation and the concentration of pitultary anterials is the same for both the in vive and the in 파 tro techniques. It has further been shown, both by wright (1945) and by the present work, that large doses of pitultary are inefiective in producing ovilation in amurans, and this is in line wh the observations of Foster, Toster, and Hisaw (1937) on the rabbit. There is a strildine similarity between both the upper and the lover 11 m ting temperatures found for the in Vitre tests in this studs, and the range of teraperatures at which the toad is active and at wich breeding takes place In neture. Yinally, it is well lenom that orulation in Five is stimalated by gonadotropic factors. In the studiea on the spadefoot, 
ueing the in Vitre teahnique, ovulation occurred only where pitultary had bsen used, and no spontaneous orralation occurred in an control vial containing Holtireter's solution. Sincs the parallelism between

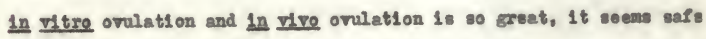
to conclude that the In Iftre technique does arford a valld wethod. of studying ovulation, at least in amurens.

Sone dfferenos heve been observed between ovalatlon in v1tro In the spadefoot and the ovalation process in other form as reported by verlous workers. Bugh (1948) reported that the pltultary of the mele Rana plofen had only about half the potenoy of the female gland. al though he stated that ths number of elands needed to Induce complets orulation veried seasonally. In the spedefoot the writer found that the malo pitultary was about 78 percent as potent as the fomals pitultary. The discrepancy between these potency values may bs due to epeciflo alfferences, since the two genera are phylogeneticaliy well separated wthin the Amura. Buch's work tested Intact fonale froge for nornal ovulation followng pitultary 1njections, and he was more or lose concerned wth an all or none response. In corrparison, the present in Itre study wae quant1tatively nors accurate. alnce a precise ovaletion percontage could be obtalned.

Agaln, Wight (1945), using Reng plniens, obtalned aedmal ovulation in pltre wth ono-elghth of a pltultary in $10 \mathrm{ml}$. of Ilusd, 
wheras one entire gland in $10 \mathrm{ml}$. of fluld was required for madimal effects In Scanhiopus holbroolst. Several lactors ind cht cause this alfference. In the first place, Wright used lenale pituitary while nele pituitary was used in the present study. But the alfference in required concentratione is too great to be sccounted for solely by the difference in potenoy of the pitultary of the two gexes. The pars distalls Irom a mature southern leopard frog is two or three tines as lerge as that fron an advit spedefoot toad. The pleces of ovary used in the two studies vers approximstely the ame elze, since the sise of the vitellus is almost identical in fians plpiens (1.3 2.0 and.) and Scaphiopus holbroold $(1.4-2.0 \mathrm{~mm}$ ). The hormone titer of the pitultary, among individuals of the same sex in a single opecies, veems to be pretty mach the same regardless of the size of the andmal or of the Bland 1tself. However, since the pituitery of the Rana piniens is wuch larger than that of Seaphlopus, It seens logical to expect thet Its hormone titer would therefore be a good deal higher. If this is true, then a portion of the gland whould yleld as wach hormone as an ent1re gland of Scanhlorss holbreold. This mey account for the apparent difference in concentration requlred to induce medinal ovalation in the two mpecles. These hormonal differences Indleate that, for experinentel purposes, a standerd method of determining the actual horwone titer is needed. Measurements in terns of nubers or fractions of pltultaries is unsatisfectory. 
A considerable difference in the time required to intilate the onset of ovulation in vitro was sound in Scaphlopus holbroold as conpared to Rane nintens. Wright (1945) found that in vitro ovulation in Rana piofient started about the tenth hour, whereas in the present work it vas found that ovalation in Scaphlores holbroold began in three and one-half hours. The explanation for the tive differences in these studies is probebly to be found in the pltultary dilutions used. Although Wright (1945) stated that none of the p1tultary allutions (ranglng Irom one thirty-second of one pituitary to two pitultarles in $10 \mathrm{ml}$. Pluid) would Inltiate breeding before the tenth hour, it wa noted, in the present study, that heavlex concentrations of pitultery intilated the ovulation response in less t1me. P1tustary dilution having the equivalent of four glands in $10 \mathrm{ml}$. of Rluid elicl ted in Itre ovilation in one and one-hals hours in Seaphlopus. It is possible that the ovarles of the opadefoot react to gonadotropins in a shorter tine than do those of most anurans, since the ent1re act of breeding and enbryonic development Is ecclerated in this form. This phenonenon is undoubtediy correlated wth the hablt of breeding in tenperary water. Irowbridge (1941) wrote, "In Scarhtonus bomblerons, the rate of developant throughout the entire enbryonic and lerval period is more rapld than that whsch has been reported for ang other amphiblen. The eleavages, In perticular, take place of th surporising speed; they are among the nost rapld cell divisions ever recorded." 
For the spedefoot tood, there is a marked slmilerity betwieen the 11mitlug and optlman temperetures for the In ritre process and ovulation and activity in nature. The lialting temperatures for the in vitro ovilation were $50^{\circ} \%$, and $86^{\circ}$ \%.; the optimel temperature, $74^{\circ} \mathrm{g}$. Pearson (1954) sound thet the activity of the spedePoot was greatest between $50^{\circ} \mathrm{T}$. and $84^{\circ} \mathrm{J}$. . Wh thadmin activity at $69^{\circ} \mathrm{J}$. which he connldered optimel temperature for this specles. Teinperature records from thirty-four spedefoot breeding choruses showed that toade bred at temperatures as lov as $47^{\circ} \mathrm{T}$. and as high es $83^{\circ} \mathrm{Y}$. Wh the mean of $71^{\circ} \mathrm{Y}$. Although induced in vive ovulation occurred in pitultery-injocted femeles at temperatures of $78^{\circ}, 61^{\circ}$. and $54^{\circ} \mathrm{r}$. It $^{\circ}$ was inhlbited at temperatures of $45^{\circ}$ and $37^{\circ} \mathrm{r}$. Apparently, the effeot of cold temperatures neex $50^{\circ} \mathrm{r}$. Inhibits the action of gonadotropic hormones in the spedefoot; this is in accord Wh th Hougsas (1954) who reported that the ection of gonsdotropins was retarded at temperatures between $39^{\circ}$ and $50^{\circ} \mathrm{J}$. In Bufo arenerum.

The phyrlological procese of in vitre ovulation in the opadeLoot toad has its ecolocteel zere (1.e.." the highest externally Imposed temperature at which a physiologicel process cennot rrecessfully be completed." - Allee et 2li., 1949) at $48^{\circ}$ \%. The erfective temperature threshold (1.e.. "the lovest temperature at which a given physiologlcal process cen be carrled through to completion." - Allee et 21., 1949) for In Itre ovilation in the spedefoot was $50^{\circ} \mathrm{I}$. This 
concept $\mathrm{m}$ ght be extended to include the upper temperature range Wh the effective temperature threshold at $86^{\circ} \mathrm{Y}$. It was noted that the in itre ovilation teaperature curve closely approxinated the theoretical curve representing the general effect of temperatruxe on antmal actirity (M1ee et el.. 1949). Like nost physiologieal processes, the optimal terperature $\left(74^{\circ} Y_{.}\right)$of ovulation in Itro 18 mach nearer the polnt of hast comn $\left(88^{\circ} \mathrm{y}.\right)$ than the point of cold narcosis $\left(48^{\circ} \mathrm{P.}\right.$.).

One of the physical factors tested for 1 ts offect upon in Itre ovilation was $\mathrm{pH}$. A sodiun veronal acetate buffer, used to test the $\mathrm{pH}$ tolerance of the in yitro process, produced complete Inhibition of ovilation in vitxe. The explanation for the inhibitory action of this buffer gysten 1s not elear. S1nce veronal, or barbital, Is used as a soporiflc, it is ent1rely possible that the narcotlc effects of the berbiturate inhiblted the ovuletion process. Fousasy (1947) showed. that the exptuleton of the ovin from the overian membrenes was âe to comprestion by smooth saseles in the foll1cular val1. It is possible that these ausele celle vere nercot1zed to such en extent that the egge could not be roleesed. Sollnan (1944) stated that an adequate amount of barblturate always depresses mooth wascles, int in varying degrees, The exact action of this narcotle is unknown. However, when a sodiun phosphate buffer was used, In ytre ovalation progresed normelly at pli values of 6.5 to 8.5. and was optimal at 7.3. 
Heteroplastic pitud tary materiels have been used extensively for the Induction of In vire orvilation (Creseer and Corbman, 1939), but the present study is the Plrst to make a wde uttilzation of intergpecific pituiteries for in vitre ovulation. The only previous In yitre study employing heteroplestic pl tul tery preparations (aheep pitustary extract) was conducted by Wright and Hisav (19/46) in Rana plplens. In the present study, heteroplastic materials, from representatives of the mejority of the vertebrate elasses, were used, but very 11 ttle could be determined quantitatively concerning the comparative anounts of pitultary required to produce equal amounts of ovilation in the varlous classes.

The complete negative results obtalned wth pl geine pltuitery are In weeord with the majority of studies whlch have employed fish pltuttary for the Induetion of in vivo ovulation in anphsblans (Creaser and Corbman, 1935, 1936, and Rostand, 1934). The fact, that the pltultaries from the true froge (Pana) and the toads (Bufo). gave ebout the sane orviation percentages as did the controls (Scaphlevus). wile those from the tree froge (Hyla) and the nerrownouthed toed (Microhrla) gave lower results, is probebly due to the size of the pl tultary glands from these enurans. The low percentage of ovilation uling pituitary from the salamander Desmonnathes Puscus eurleulatus Is In agreement wth the work of Adaws and Grenger (1938) who found that in vive ovilation in Rene plolene covld only be induced with 
large numbers of Iriturug pl tuitarles. P1 tul tary from both snake (Itatr) and $11 \operatorname{sard}$ (Scelooomas) induced low percentages of ovulat1on whon compered w th pltultary front the control Scanhlopus, velt even so, this is the flrat successful attempt at stimulating gonad activity in Amphibia with the reptilian pituitary. The only other study whlch used reptillan glands (anake - Xenodon) to Induce ovilation gave negative recrults in Bufo sxenemen (Housas and Giust1, 1929). Blrd pitultary has proved varlable in inducing ovulation in Amphlb1e. Houssay and Oinst1 (1929) and Creeser and Corbman (1939) obtalned negative results when they used chickon pituitary on the toad and frog, wh1ls Stein (1934) and Witachl et 이. (1937) Pound that avlan pitultary would induce orulation in the nevt Ixiturus. The present study is the plrat to successfully ut1lize arlan pl tultary to Induce orulation in the Anure.

Creaser and Corbanan (1939) stated that those Anphibla which are responsive to mavenallan p1tultary preparat1 ons, require large doses to Induce ovulation due to the phylogenetic, limlting factor. In the 11 ght of this statement, the censitivity of In vitre ovulation to the majority of mamallen hypophyseal preparatione is remexicable. In the present work, only two of the mamnalian pitultary anterial. used gave negative renulta and there is a posalble explanation for one of these. The fallure of the swine gonadotrople fraction to induce in V1tre ovulation might be due to the nethod of 
preparation of the desiccated powder; possibly the proteln complex In the hormone was denatured or eltered in some way. Actually. this gonadotropic fraction should be more offective in ellelting orulation In vitro than the whole pltustery or the anterlor lobe preparations.

The fallure of the chorlonic gonedotropin, from humen pregneney urine (extract and whole urine), to inltiate in yitze ovalati on in Scaphlorus was not surpriaing. since thirteen of fifteen tests, using humen pregnency urine, were unmuccesaful in inducing ovulation in eleven different species of Anura. Both Eensen (1951) and Knepton (1951) Pound that 1t was imposalble to induce spermiation in the aale apedefoot by the injection of humen pregnancy urine or commerclal hwasn chorlonic gonadotropin. The Insensitiveneas of both the mele and femele Scaphlonne to humen chorlonle gonadotropla may well 111ustrate phylogenet1e meelplelty.

Although most naturellats recognl ze that the eastern spadefoot toad breeds over a brosd range of months durlng the gpring and surmer, the majity 1mply that the breedsng of this forn follows a cycllo, sesoonal pattern. sceording to the avallable breeding record, Scaphlorpas breods more often in the spring ( 57 choruses) and summer (45 choruses) then in the fall (12 choruses) and inter (7 choruses), because oultable onvironmental conditions (heavy rafnfall and optlmal temperatures) appear with greater frequency in the spring and sumer. 
Nevertheless, this does not negate the fact that breeding ney occur at any time of the year then the temperature and ratniall permit. If extensive recorde had beon kept, it is almost certid $n$ that spadofoot breeding would have been reported for every month in the year. but no reoords are avallable for November and December.

The range of months in which spadefoot toads have been reported to breed veries Irom five month (Apr1I to Areust) in the northern states, to olx months (March to Ausust) in the aldale states and ten monthe (January to Oetober) in the southern states. The differences in the range of breeding months for these three geographle areas are almost certainly due to temperature and not rainfall. Undoubtedly, the low temperatures from september to the following spring prevent fall and winter breeding in the northern, as well as, In the mldale states. In the southern states, the mlder temperatures soldom aet as a $11 \mathrm{miting}$ factor, and breeding occurs as early as Tebruery and as late as Oetober.

In some portions of the spedefoot's range, there is an intensity of breeding during cartaln wonths. In the northern states, it 10 probable that the eyclic weather conditions are repeated w th enough regularity each year to produce the preponderance of breedine wich occurs in Apri1. The apedefoots of the mddale eastern states show very Iittle fluctuation in breeding intensity for any nonth. 
In the southern pert of the range, there reens to be an increase in breeding in Jebrwery and March and agal $n$ in August, September, and October. The number of records for June is also high. It is poselble that breeding takes place at ebout the sane rate in oach month wth a deciline between Ootober and Februery, due to colder terperatures. The paucity of July breeding reoords for Ylorida, as well as for the other southern states, presents a probles, especially when this wonth has one of the hlghest rates of preclpitation. A review of the Jlorids preelpitation recosds Irom 1893 to 1927 showed that July had more daye with rainfell than any other month of the yoar (Mitchell and Insign, 1928). Thls would indicate that Julg rainfall is not as Intense as the sporedic rains of other months that have equal or zore total precipitation. It is during hoavg oporadle ralnfall that gpedefoots generally breed.

It Is now elear that the eestern spadefoot does not follov a seasonal breeding pattern, but breeds at any time when the proper onvironimentel conditions prevall. Since most Amphibla resorb their egg then unfavorable conditions exdst during thelr usual breeding season, the retentlon of meture, Fisble egge by the spadefoot would seem to present a physiological problem. If Scaphlorves follows the general pattern of nost emurens, It is possible that there is a constant resorption of post-mature ove accompenied by a production of newly maturing ergss. It geems 11 kely that this is the case, 
ince even the most meture ovarles ponsese come imature oggs in various stages of developaent. On a fev occeslons, it was sound thet overies from gome females contained practleslly all imature, yolk-defleient egEs, even thouges breoding had not oceurred for an extended period. There is the posalbility thet individrels resorb their eggs, according to thelr particular eycle, at various times of the year. There is a remote poselbility that spedefoots are able to retaln mature egge unt1l they breed, regardless of the tine lapse since the last breeding, whlch in some cased may be several years or more. A thorough study of this problen is definitely needed.

One of the problems inherent in working wh theesonal breeding In Amphibla is whether it is better to dispense $\mathrm{w}$ th experiaental work until the species may be uged for breeding again, or to use two or more specles which have differest breeding seasons. This study has show that the spadefoot is not a seasonel breeder, but produces mature eggs and spern at all seasons of the year. ThereLore, for embryologists, endocrinologists, and others, Seephlopue holbroold affords a year round. aupply of ovarlan or exbryonte metertal from a single specles.

It appears felrly certel n that breeding in the apedefoot toed 1s Infilated by the otimulating effects of heavy rainfall and optimel temperatures. Ixsetly how these stimull affect the toad is unknoim. Since it is knom that the overles are extremely sensitive 
to gonadotropic secret1ons, It was hoped that the in 멸o technlque might be employed to test whe ther stimull stinnlating environmentel conditions would cause the hypophysl s to release hypersecretions of gonadotropln which sensltize the ovarles. In ritre ovilation results obtalnod from experinental femeles exposed to 11 ght, abrupt changes of temperature, and lowered atmospherle preseure, for a pertod of forty-eight hours, did not differ slgnifl cantly from results obtalned fron control animels. Hoverer, experlmental females exposed to weter gave ignlficantly hlgher ovulation percentages than controls lopt in a dry state. Using a Gradi ont of soll nolstures, It was found that ovilation in flite wes correlated with vater-uptake which is dependent upon the amount of soll molsture. Tomales subjected to a gradient of humidity chambers ( $98 \%$ to $0 \%$ ) also showed that there was a direct correlation between orulation results and percent humldity. The ronson that ovulation was generally lower in toads exposed to a humidity gradient was that the were not in direct contact with water. It has long been known that Amphibis cannot absorb water from the alr even though It may be sully saturated (Adolph, 1932).

It 1s well established that the antidiuretle hormone secreted by the nevrohypophysis (posterlor lobe) controls weter balance in anurans. An 1nerease in the osmotic pressure of the blood and body fludds stimulated the secretion of this hormone, which ceuses 
Increased watermptake throuch the sidn and reterds the rete of urine formation by means of flomeruler constriction. It is gulte poselble that the vater regulatory function is in some way t1ed up whth ovulation regulation. Mhis might be the case vince normel ovulation only occurs in spadefoots in which water-uptake has talcen place. This may be indirect evidence that hypotonlc blood and body Plusd act upon the pitultery, causing it to release gonedotropins. Fousear (1949) reports that gonadotropins can be 1 solated from the blood at the time of breeding. In the present study it was possible to 1solate only one speciflc environmental stiwlus affecting the goneds; thet 18, vater-viptelce.

Frow this polnt, the witer would like to postulate, In accordance with experlmental and Ileld observations, on what are belleved to be the steps Involved in spadefoot breeding. In the is burrows, epedefoote are subject to desiccetion or hydretion, dependIng upon the nolsture content of the so11. Bragg (1944) suggested that the depth of the burrov is correlated 1 th the amount of soll nolsture. When ralniall is gufficient to produce a soll molsture great enoves to be absorbed by the toeds, water-uptaice occurs and each toad's body Plulds are replent ched, wh thexcess Iutds belng stored in the Iyuph secs and bladder. The se frets are In accord wh recent worics dealling with the relationship of anuran vater econory to terreatrial1an (Thorson, 2955, shex, 1950, and Thoreon and Svinla, 1943). 
Females are physlologlcally conditioned for breeding once the ovarles have been sensl tized by water-upteke. It ham also been shown that the pltudtary-1njected male anurans w1l not release sperm, even after "histological spermdatlon" has occurred, if insuPl1c1ent body Rluids prevent urIne formation (Vallo, Penhos, and Houssay, 1952). It seems 11kely, therefore, thet excssalve relas are needed for water-uptalce by both male and femals mpedefoote before breeding can occur.

The actual mechenlsa stimalating the males to call and polro to enter amplerus is not lenoum. The folloving explanation seems plaustble in the light of field observations. Both meles and fomeles heve been collected from low besing and flelds. At tines of heary rainfell, vater collects in these areas and forns temporary ponds In which breeding choruses have been found. Maleg and feneles, heving burrow in these low exeas, where the ground is elret eaturated, are the flrst to be conditioned by vater-uptake. Heavy raln eventually Iorma a tenporery pond which covers the area where these burrows were located. Loads which are Ilooded Iron their burrowe exe probably the inltiators of the breeding chorus. S1nce the vriter has repeatedy observed that neles 111 Imediately clasp feneles when the two sezes are placed together in water. It seeme probable that the sirst anplexing palrs would be those individuals which cone Into contact whlle floating at the surface of the acounulating vater. 
In a sense, the repld formation of such temporery ponds is comperable to placing the spedefoot in vater vhere amplexan is known to occur. Thls would seen to explain the reason why speadefoots do not nigrate to permenent ponds for breeding. The breeding ponds anst, 11 gurativeIy gpealdng, be brought to them, and this is essentlally whet talso place when temporary ponds are formed over their burrows. Once toads are flooded from thelr burrows, Iree meles utter loud, harah, breeding calls which, according to most naturallste, stimulete both palss and feneles to ufigrate to the breeding chorus.

On one occasion (Pebruary 7, 1955, Gatneeville, Ylortda), the witer observed a smell chorus (15 to 30 opodefoots) breeding in a tesporery pond. Fundreds of apadefoots remalned in and near their burrowe on the eurrounding slopes, apperently unstimulated by the call from these meles. Thl e fact probably explain how breeding cen occur in a large population many times during a fiven year.

There 1 s the possiblity that the soll on the higher ground d1d not contaln eufelclent nolsture to allov optimal vater-uptake by the toads occupylng these areas. Possibly spadefoots only breed when flooded Iron their burrovs, and those living in higher areas breed only when torrent1al dompoure occurs. The fect thet spedefoots do not frequent permenent ponds, even in heevs rainiall, supports the 1dee that they normally breed only when flooded from thelr burrows. 
During arriexus, laxge secretions of gonedotropins cause individual of occh sex to liberate and expel their respective gametes: spera in the male (spermation) and ova in the female (ovilation).

The present study on in yitro ovulation in Seaphlopus holbroold has shown that the natural breeding process of this form merits Purther Investlgatlon. 


\section{SUMMARY}

1. The physlologloal and ecologleal aspects of in ditre ovulation of the eastern epadefoot toad, Scanhtorus holbroold. were studled. Irom Nay, 1954, through July, 1955.

2. A total of 1007 nale and femele spadefoot toads, collected nar Galnesville, Florlda, were used as pitultary and ovarlan donors.

3. Pleces of spadefoot ovarles vere suspended, on cotton threads, in gtoppered V1els contalning pltultary materlals nacerated in Holtfreter's solut1on. Percentages of oviatlon were deterained by dividing the number of eggs ovilated by the total number of egga present in the ovarlen Iragment and multiplylag by 100.

4. Nale spadefoot pltultary was found to be approxdmately 78 percent as potent as Semele pltultery in evolins ovulation in Itro.

5. Mithough 1ndividual variation in ovulation percentages was relativeIf hlgh, no signiflcant differences vere obtalned anons individuals when a number of teats were nade.

6. In experiments involving 371 separate in ditro tests, little or no correlation was found between the sise of the male pituitery donox (In effect, the alze of the pituitary) and the degree of ovrilation induced.

7. Ho relationship was found to exd st between the siso of ferele ovarlan donors and the percentage of ovuletion. 
8. A dilution of one pituitary ruspended in $10 \mathrm{ml}$. of Holtereter's solution evoked maximal in ritre ovulation, while concentrations above and below thle dilution tended to produce smaller percentages of orviation.

9. When a dilution of one pituitary in $10 \mathrm{ml}$. of solution vas used, ovulation in Itre began in three and one-half hours and was completed after eleven and one-half hours. Ovulation was most rapid in the three hours immediately following its inft1at1on, It th a mardmal peak durling the third hour.

10. Iieht and darkness had no apparent effect on in vitre ovilation.

11. In ytiro ovuletion occurred between $10^{\circ}$ and $30^{\circ} \mathrm{c}$. , wh th an opt1mun temperature at about $24^{\circ} \mathrm{C}$. Complete 1nhibition occurred at $9^{\circ}$ and $31^{\circ} \mathrm{C}$.

12. Ovalation in ㅍtre occurred between $\mathrm{ph}$ values of 6.5 and 8.5 in a $0.07 n$ sodiun phosphate buffering system. Maxinal activity took place near the point of neutrallty, at a pil of 7.3. The complete inhibition of ovilation resulting fron the use of a veronal acetate buffer was probably due to the narcotic effects of the veronal.

13. Heteroplastle pitultary materials from representatives of most of the vertebrate classes were used in the induction of ovulation In vitre. Amphiblan, rept1lian, avian, and the majority of mamal1an pltultary preparations evoked ovulation, whle plscine pitultary. wine gonadotropin fractlons, and human chorionlc gonadotropins 
reacted negatively. The present study was the lirst to successfully ut1lize reptilian and avlan pltuitarles for the induction of ovulation in the Anura.

14. A study of avaliable records Indlested that breeding in the spedefoot does not follow a cyelic, seasonal pattern, but mag oceur In almost eny month of the rear. Breading appears to be infliated by a comblnation of heary ralnfall and warn temperature.

15. Using the in vitro ovulation technique it was possible to test for ovarian sensitization. Exposure of fenales to 11 ght and darlneas, abrupt ahanges of texperature, and lowered atmospherio pressure produced no apperent effect upon in vitre ovulation. Howerer, then femeles were pleced in contect wh water or exposed to high hurdalties, signifleantly higher percentages of In vitre ovilation were obtained. It has been suggested that vatermptake may stianlate the hypophysis to release conadotroplas whlch subeequently senslt1ze the ovarles.

16. Hypophysectomy of fenele toods caused a sensit1zation of the ovarles whlch resulted in hicher in yltro ovilation percentegea,

17. A monthly study of gpadefoot gonads reveiled no seasonal rarlation in the condition of elther the overy or the test1:

18. Beceuse of the marked parallelian between ovalati on in ditre and ovalation 1n Five. It vas conclades that the in vitro technique afforded a valld method of studying ameran ovulation. 
29. It has been observed that spedefoots are active in neture between $50^{\circ}$ and $84^{\circ} \%$. Wt th an optimus of $69^{\circ} \%$., while breeding oceurs between $47^{\circ}$ and $83^{\circ} \%$. wh th an opth unaw of $71^{\circ} \mathrm{r}$. The maricod ol milarlty between these temperatures and the 11miting $\left(50^{\circ}-86^{\circ} \mathrm{J}_{.}\right)$and opt1 mam $\left(74^{\circ} \mathrm{y}.\right)$ temperatures for in vitre ovilation. Lends further sunport to the valldity of the la vitre technt que.

20. Since the majorlty of spedefoot toads retaln mature ove and eperm throughout all seasons, they afford an excellent source of ovarlan and embryonic material for the embryologtst, endocrinoloclat, and others.

21. Under natural conditions, vater-uptake is necessary to the female for ovarlan sensitisation and for urine formation thloh provides a modium for the transportation of apern in the sale. It is therefore wuegested that toads which are flooded from thelr buxrow in the low areas probably are the first to instlate the breeding chorris. 
Abbott, C. C.

1884. Recent studies of the spadefoot toad. Amex. Iatural1:t. 18(11): 1075-1080.

1904. One explanation of reported showers of toads. Proc. Aner. Phil. Soc. 43: 163-164.

Adems, 1. E.

1930. The 1nduction of ogg laying in Trt turus virdescens by heteroplastic pitutery gland grafts. Anat. Rec. 45: 250.

Adams, A. B. and B. Granger

1936. Induction of orvlation in Rana plofens by pltuitarles of Irlturus virldescens. Proc. Soc. Ixp. B101. and Med. 38: 552-554.

Mdolph, 3. T.

1932. The vepor tension relet1 on of Pross. Blol. Bull. 62 112-125.

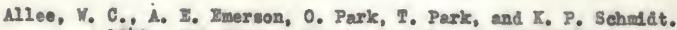
1949. Principles of animal ecoloest. Philadelphiat $W$. B. Saunders. $x 11+837$ pp.

Allen, J. A.

1868. Catalog of the rept1les and batrachlens found in the viclatity of Springlield, Massachuset ts, id th notlces of all the other specles lenown to Inhablt the state. Proc. Boston Soc. Nat. BI st. 12: 171-20 4.

Allen, Morrow 3 .

1932. A survey of the anphlblens and rept1 les of Harrison County, M1 sal ssippl. Amer. Mugeun Iovitates. S421 1-20.

Aschein, S.

1926. Uber die functlon des ovariumg. ztschr. f. Geburtah U Oynak. $90: 387-390$.

Ball, S. C.

1936. The distribution and behav1oz of the spadefoot toad in Connectiout. Trens. Conn. Acad. of Arts and Sc1. 32: $351-379$. 
Barth, L.

1944. Imbryologg. Nev Yorkt The Dryden Press. $z i 1+$ $330 \mathrm{pp}$.

Bragg, Arthur $\mathrm{X}$.

1944. The spedefoot toeds in Oklahome with a mumary of our lonowledge of the group, I. Amer. Mlaturalist. 78: 517-533.

2945. The opedofoot toad In Okiahoma whth a summary of our knowledge of the group. II. Amer. Inaturell st. 79: $52-72$.

Brandt, B. B.

1936. The frog and toads of eastern Morth Carollns. Copela 1936(4): 215-223.

Brimley, 0. S.

1896. Batrachls found at Male1 gh, North Garolina. Amer. Iinturallet. $30: 500-501$.

Cars, Archte 5.

1940. A contribution to the herpetolog of rlorida. Univ. of Jlorida. Blol. Sef, Serles $3(1): 1-118$.

Creacer, C. Y. and A. Gorbman

1935. Apparent apeciflelty of the Induced ovaletion reaction in exphibia. Aner. Jour. Physiol. 113: 32.

1936. Specifleity of the pituitary gonedotrople factor as demonstrated in amphibla. Cope1a $2936(2), 91-95$.

1939. Species spectilel ty of the gonadotroplo factors in vertebrates. quirt. Rev. B101. 14(3): 311-331.

Counininghem, J. T. and W. A. Smart.

1934. The structure and origin of corpera latea in some of the lower vertebrates. Proc. Roy. Soc., Iondon. 116(B): 258-281.

Davis, พ. พ.

1908. Notes on Ilow Jereey amphiblens and reptiles. Proc. Staten Is. Assoc. Arts. Selences, 2(2): $48-49$.

Deekert, R. 7 .

1921. Amphtbian notes from Dade County, rlorlde. Copela 2921(91): 20-23. 
Drtver, Frnest $C$.

1936. Observations on Seanhlopus holbrookl1 (Herlen). Copela 1936(1): 67-69.

Dunn, ., R.

1930. Rept1les and amphlblans of Northampton and vicinity. Juil. Boston soc. Nat. H1 st. 57: 5-8,

Ever, R. T.

1950. The effect of pitultrin infection on the water balance of Bufe realserls Reuss. Jour. Ixp, B101, 27(1): $40-49$.

Foster, M. A., R. C. Poster, and Y. I. Hl saw

1937. The interrelationship of the pitultery sex hormones In ovilation, corpus luteun fornation and corpus luteon secretion in the hypophysectoril zed rabbit. Indocrinolosg. 211 249-259.

Friedman, M. H.

1929. Mechand sms of orulation in the rebblt. Amer. Jour. Phyriol. 90: 617-622.

Gilnore, R. J.

1924. Hotes on the 11fe hIstory and feeding hablts of the spedefoot toad of the western plains. Colorado College Publ. (Sel. Serles). 13(1): 1-12.

GLovannoll, Leonard

1936. Seaphlopus holbroolds in Kentuckg. Copel a 1936 (1):

Gomori, George.

1952. Microseople histochend atry. Chlcago: Univeralty of Chlcago Press. v1 +273 pp.

Gortner, R. A. Jx. and W. A. Gortner

1949. Outlines of blochemiletry. Hew Yorks John wiley and Sons, Ine. pp. 88-89.

Comer, $x_{\text {. I. }}$ and Irving $\mathrm{H}$. Black

1954. Larval eevelopment in Bufe roodhouged coviers and Scerhlorens h. holbrookd. Copela 1954(4): 251-255.

Oreen, I. B.

1948. The opadefoot toad, Scaph10pus $h$. holbroold1, breedIne in Southern Oh10. Copela 19i8(1): 65. 
Groen, I. B. and I. D. Richmond

1940. Two armhibiens new to the herpeto-fauns of west virelnia. Copela $1940(2): 127$.

Hansen, Ke1 th $\mathrm{Z}$.

1951. An 1nvestigation of native rlorida male sal1ent1a as test animals for early pregnancy diagnosis. Gart. Jour. Fla. Acad. Sc1. 14(4); 231-236.

Fargltt, $c . w$.

1888. Recent notes on Seanhionus holbroolds. Aner. Natural1st. 22(258): 535-537.

Hel Ibrunn, I. V., K. Deugherty, and I. K. MI lbur.

1939. Int tiation of meturation in the fros egg. Phyel ol. 2001. 12: 97-100.

II saw, I. L., R. C. Greep, and H. L. Tevold

1935. Ixperimentel ovulation of the Macreus thegus monkeys. Anat. Rec. 64 i 34.

Hol tereter, Johannes

1945. Neutral1 setion and epideral zation of gastrule ectoderm. Jour. Zxp. Zool. 96, 161-209.

Eousgey, Bernardo A.

1930. Acclón sezual de le hlpórls1s on los peces $y$ reptiles. Rev. Soc. Argentins B101. 6i 686-688.

1931. Aot1 on sexuelle de 1'hypophyse sur les polssons ot les rept1les. Compt. rend. Soc. de Blol. 106: $377-378$.

1947. Ovralación del sapo Bufo erenamun Hensel. Rev. Soc. Argentine B101. 23(2) 186-195.

1949. Eypophyseal functions in the toad Bufo arenaru Hensel. Quart. Rev. Bol. 24(1): 1-27.

1954. Eormonal regulation of the serval function of the ale toad. Acta Physiol. Iatinoamer. $4: 2-41$.

Houseay, Bernerdo $A_{\text {, , end }} \mathrm{L}_{\text {. Giust1 }}$

1929. Las function de la hipósisle g de la restón 1nfundbulo-tuberlans del vapo Bufo srenerun Bensel. Rev. 8oc. Argentina B101. 5i 397-418. 
Knepton, J. C.. Jr.

1951. The reaponses of male sallentla to human chorlonie gonadotrople hormone. Quart. Jour. Fla. Acad. Sel. $14(4): 255-265$.

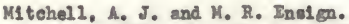

1928. The ellmate of Forida. Untv. of Florlda. Ag. Ixp. Sta. Bull. 200: 91-300.

Nationel Research Councll

1926. Internat1onal crtical tables of muerical data, physice, chomstry. and technoloss. Vol. I. Irew Torkt HoGraw-E111 Book Co., Ino.

Menols, Andrev

1852. Occurrence of Scerhionus sollterine in Isser County. wh theme notlces of 1 t $h$ istory, hablts, tc. Jour. Issex County Iat. F1st. Soc. 1(3): 113-117.

Iichols, 3. T.

1917. Spadefoot toad at Mastic, Long Island. Copela 1917 (45): $59-60$.

Noble, G. $\mathrm{X}$.

1931. The blolog of the amphtb1a. Iew Yorka Mefrew-8111 Book Co., Inc. $x 11+577$ pp.

1936. The sunet1 on of the corpus strletum in the social behavlor of 11shes. Anat. Rec. 63: (Suppl. 3) $3^{4}$.

Obrecht, C. B.

1946. Jotes on South Caralina rept1les and anph1b1ans. Cope1s 1946(2): 71-74.

Overton, Irank

1914. Iong I aland fauna and flora III. The frogs and toads. Mus. Hrooklyn Inst. Arts Seleness, Sclence Bul1. 2(3): 28-30.

1915a. Annual occurrence of spedefoot toads. Copela 1915 (20): 17.

1915b. Iate-breoding spadefoot toads, tc. Copela 1915 (24): $52-53$. 
Pearson, Paur 0.

1954. Population seoloes of the spadefoot toad, Scarlopun h. holbroold. (Unpublished $\mathrm{Fh}$. D. dissertat1 on, Dept. of Blology, University of rlorida). $v^{+}$ 166 pp.

P1ke, N1 choles

1886. Notes on the hernst mpadefoot. Bull. Amer. Mus. Nat. H1st. $1(7): 213-221$.

Putnem, I. W.

1865. Some statements concerning Irogs and toads found about Cambridge, Massachusetts. Proc. Boston Soc. Nat. H1st. 2: 229-230.

Quinby, John A.

1954. Interesting breeding dates for some South Caroline Irogs. Zerpetologica. 10(1): 8.

R1 chmond, X. D.

1947. I1fe history of Scaphionts h. holbroold (Harlan). Part I: Larval development and behavlor. Bcology. 28: $53-67$.

RIddle, 0 . and $Y$. Tlemion.

1928. Studies on the physlology of reproduction in b1rds. Amer. Jour. Phys101. 87: 110-123.

Ronde11, Paul A.

1953. In vitre stud1es on ovvlatory mechenism in the frog, Rana nlplens. (Unpublished $\mathrm{Ph}$. D. dissertation, Dept. of Blology. University of Miohigan). $v+52 \mathrm{pp}$.

Rostand, J.

1934. Hypophyse et ovulation ches les butraclens. Compt. rend. Soc, de Blol. 117: 1079-1081.

Rugh, Roberts

1934. Induced ovulation and artif1cial fert11ization in the Irog. B1ol. Bull. 66: 22-29.

1935. Ovrlation in the frog. I P1tuitary relat1on in Indueed ovilation. II Tollievler rupture to fertll1zation. Jour. Ixp. Zool. 711 149-193. 
Rugh, Roberts (cont1med)

1937. A quentitative analyel s of the pltultary-orulation relation in the Prog, Rane pliniens. Phyel ol. Zool. 10: $84-100$.

1939. Relation of the intact pl tol tary Gland to artificlally Induced ovulation. Proc. Soc. Ixper. B101, and Mod. 40: $132-136$.

1948. Experimental embryology, a manuel of techniques and procedures. Minneapolis, Minn.t Burgess Publighing Cospany. VI1 $+480 \mathrm{pp}$.

1951. The Prog; 1te reproductlon and development. Philadelphia: Blald ston. $x+336 \mathrm{pp}$.

Ryan, Y. J. and R. Grant

1940. The stimalus for maturation and for ovulation of the frog' egg. Phyelol. 2001. 13: 383-390.

Shaplro, H. A.

1936. The blologtcal basis of sexual behavior in amphiba. Jour. $\operatorname{Exp}$. B101. 13: 48-59.

Sherwood, Willam $\mathrm{L}$.

1897. The frogs and toade found in the vielnity of New York C1ty. Proc. IInn. Soc. of Hew York, 10: 17-18.

Smlth, T. S.

1879. The opodefoot in Hev Haven, Connecticut. Amer. Nia turallst. $13(10): 651-652$.

Sint th, P. $\mathrm{s}$.

1926. Hastening development of female genital system by dafly momeoplastic pituitery 1mplents. Proc. Soc. ixp. B101. 6: 190-204.

Smlth, Ralph $\mathrm{F}$.

1952. Occurrence of the spedeloot toad, Seaphlogus $h$. holbroold (Haxlan), near Albeng, Hew York. Copela $1952(1): 48$.

Sollman, Torald

1944. A manual of phermacoloes and 1 ts application to therapertics and tordeologr. Philadolphia: W. B. Saunders Compeny. $x+1298 \mathrm{pp}$. 
Spangler, Paul J.

1950. Occurrence of Scanhlorue h. holbrooldl (Harlan) in Athens County. Oh10. Oh10 Jour. of Sclence. SO(6): 277.

Stein, $\mathrm{x} . \mathrm{Y}$.

1934. Wifects of avian pltultary glands in salamanders. Proc. Soc. Ixp. Blol. and Med. 32t 157-161.

Svenson, Paul L.

1938. Pt tuonhis and Scephlonus in Indlans. Amer. Midl. Het. $20(3): 713$.

Tanner, $\nabla . \mathrm{K}_{\text {. }}$

1939. A study of the genus Scaphionus. Groat Basin lat. $1(1)$ : $3-26$.

Thorson, Thomes B.

1955. The relat1onohip of water economg to terrestrialien in emphtbians. Jeology. 36(1): 100-116.

Thorson, Thomas B. and Arthur Svihla

1943. Correlation of the hebitats of amphiblans wh thels abli1ty to eurvive the loss of body vater. Icology. $24(3): 374-381$.

Trovbridge, A. R. and H. S. Trowbridge

1937. Notes on the cleavage rate of Sceohlonus bomblrrons Cope ith additlonel reasarts on certaln appects of 1ts life history. Amer. Batural1st. $71 i 460-480$.

Trowbridge, $M_{.} \mathrm{s}$.

1941. Studies on the normel development of Scaphlopus bomblerons Cope I. The eleavage period. Trans. Aner. M1 erov. 800 . $60: 508-526$.

v. \$. Department of Commeree

Climatologloal data. Ylorida. Vol. XCXV-LIX (1921-1955).

Weshingtori: Government Printing Office.

Valle, J. R..J. C. Ponhos, and B. A. Housasy

1952. Vias de administracion $y$ absorclon de gonadotrofinas en sapos wachos. Rev. Soc. Argentin Blol. 28: 1.

Van Hyning, T.

1923. A collecting note on Florida batrachina. Copela $1923(118): 68$. 
Wheeler, M111am Morton

1926. Ants, thel $x$ structure, development and behevior. Nev Yorkt Columbla University Press. xav 4663 pp.

W1 tachl, I., A. J. Stanley, and G. K. R1ley

1937. Gonadotropic hornones of the hypophyels of the turkey. Proc. Soe. Exp. B101. and Med. 36: 647-651.

Wolf, 0. M.

1929. Iffects of dafly transplants of anterlor lobes of pitultary on reproduction of froge. Proc. Soc. Ixp. 2101. and Med. 26: 692-693.

Wright, Albert Basen

1932. Ife $\mathrm{historles}$ of the froge of the Okelinolose Swamp. Ceorgla. Inew Tork: The MadM1Ian Coupany. xT 497 pp.

Wrlght, Albert Razen and Ams Allen Wright

1949. Handbook of 1 rogs and toads. Now Tork: Comstock Publishtng Company. Ine. $x d 1$ * 640 pp.

Viright, Paul A.

1945. Fectors affecting in Fitro ovilation in the frog. Jovr. Ixp. 2001. 100(3): 565-575.

1946. Sensit1 gation of the frog ovary following hypophyrectomy. Phys101. 2001. 19(4): 359-364.

Virl ght, Paul A. and $Y$. L. FI naw

1946. Iffect of mamralian gonadotropins on ovilation in the fros. Rara plinlens. Indoorinologe. 39(4): $247-255$.

Wright, Paul A. and Malcola r. Macintyre

1950. Conadotroplc activity of blood serva frov hypophysectoml sed frogs, Rans plolens. Physiol. Zool. $23(1): 16-22$.

Zondek, B.

1926. Uberd1 funetion des ovarluns. Ztsch. 1. Geburtah. U. Gyake. 90: 372-374. 


\section{PLATE I}

Y16. 1. Single exciged gpadefoot ovary contalning nine ecgfllied lobes.

P15. 2. V1al-reck holding vials which contain ovarlan Iragnents sugpended on cotton threads in pituitary extract.

116. 3. Control vial (left) contalning only Holtireter's solution and experimental vial ( $r$ ght) contal ning Holtireter's solution and p1tultary horogenate. Igge at the bottom of the experimentel vial have been ovulated from the handing overlen Iragnent. 
PLATL I

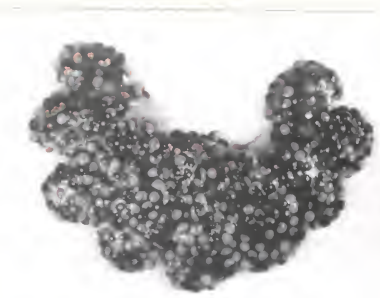

1.

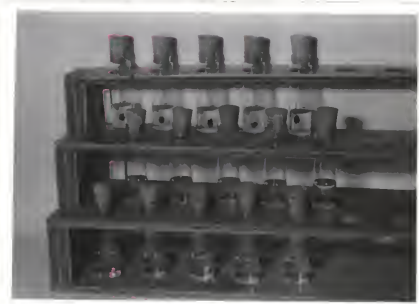

2.

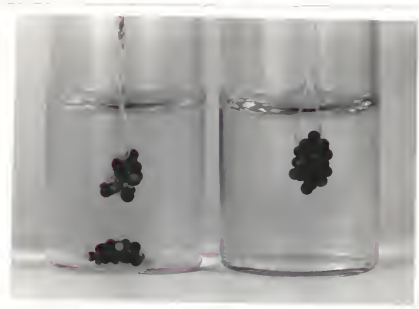

3. 
Mig. 1. Ventral View of excised spadefoot cranfun severed through the cervical region and angle of the Jav.

J1E. 2. Crantum showng exposed parasphenold bone after the xemoval of the oral sueose from the rool of the mouth.

rig. 3. Crantum wth brain case opened ventrally, showing the exposed pituitery gland (anell whito lobe) fust posterlor to the optic ohlaeme. 
PuArs II

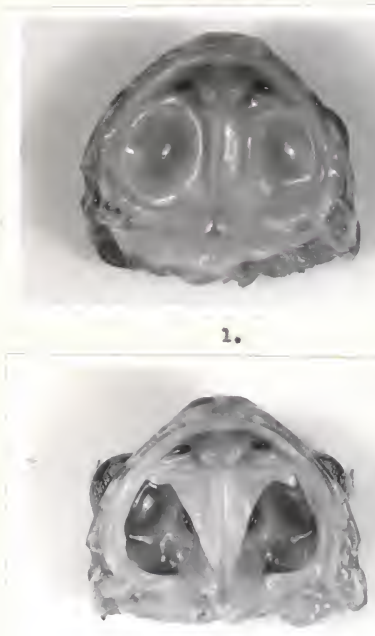

2.

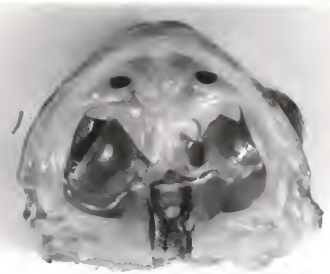

3. 


\section{BIOCRAPHCAT SKMTCR}

Xeith Leyton Hansen, born Yovember 14, 1925, in Gainesville, Florida, attended schools in Jackonville, Florida. After graduation Irom Anarev Jackenon Sentor High School in 1943, he sttended the Undverstity of rlortds for one sementer. From Kerch, 1944, to July. 1946, he served in the unsted states Arng. He entered John B. Stetson University in 1946 . He vas marrled to the Porner Mary Juent ta Turner of Jacksonv1lle, Florida, In August, 1947. Hav1ng graduated from Stetson Univereity wh a Bacholor of Selence degree cun Ievalo In Augrst, 1949, he bogan gradrate studies in September, 1949, and recelved a haster of sclence degree in August, 1950. Imsle at stetson University, he served as a eraduste sselstant. He ves omployed as an Instructor In blolocg srom September, 1950, to June, 1951. Then ho began graduate studies at the University of rlorlda. Male attendIns the Oniverat ty of rlorida, he was employed as a graduate sasletant until August, 1954. Then he was avarded a gradusto followshlp unt11 August, 1955.

He holds memberahly in Ilorida scadery of Sclences, Herpetologists League, American Society of Ichthyologlsts and Herpetologlsts, American Aseoclation for the Mdvancenent of Scilence, Beta Bete Beta, Kappe. Dolta P1. Phi s1gma, and S1gma X1. 
This dissertation was prepared under the direction of the chalrnen of the candidate's eupervi sory cound tise and hes been approved by all members of the commltee. It wes submatted to the Dean of the College of Arte and Sclences and to the Gradusto Councll end vas approved as partial fulf1 liment of the requifenents for tho degree of Doctor of Phslosophy.

August 13, 1955

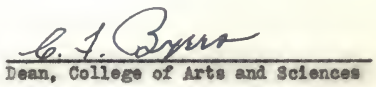

Deen, Graduete School

SUPयRISORT COMTITEE:
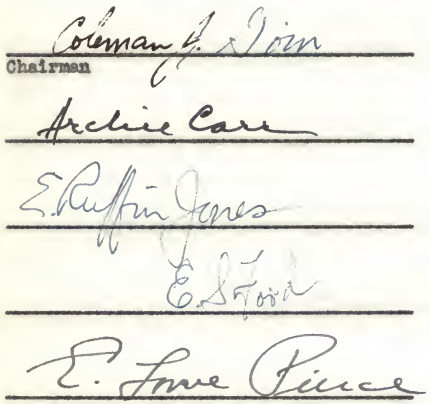